\title{
Development of a Continuous Liquid-Fed Laboratory-Scale Mini-Melter for Nuclear Waste Glass Development
}
M. A. H. Reimus
S. C. Marschman
G. L. Graff

February 1987

Prepared for the U.S. Department of Energy under Contract DE-AC06-76RLO 1830

Pacific Northwest Laboratory Operated for the U.S. Department of Energy by Battelle Memorial Institute 


\title{
DISCLAIMER
}

This report was prepared as an account of work sponsored by an agency of the United States Government. Neither the United States Government nor any agency thereof, nor Battelle Memorial Institute, nor any of their employees, makes any warranty, expressed or implied, or assumes any legal liability or responsibility for the accuracy, completeness, or usefulness of any information, apparatus, product, or process disclosed, or represents that its use would not infringe privately owned rights. Reference herein to any specific commercial product, process, or service by trade name, trademark, manufacturer, or otherwise, does not necessarily constitute or imply its endorsement, recommendation, or favoring by the United States Government of any agency thereof, or Battelle Memorial Institute. The views and opinions of authors expressed herein do not necessarly state or reflect those of the United States Government or any agency thereof, or Battelle Memorial Institute.

\author{
PACIFIC NORTHWEST LABORATORY \\ operated by \\ BATTELLE MEMORIAL INSTITUTE \\ for the \\ UNITED STATES DEPARTMENT OF ENERGY \\ under Contract DE-AC06-76RLO 1830
}

\begin{tabular}{|c|c|}
\hline \multirow{2}{*}{\multicolumn{2}{|c|}{ Printed in the United States of America }} \\
\hline & \\
\hline \multicolumn{2}{|c|}{$\begin{array}{l}\text { Available from } \\
\text { National Technical Information Service }\end{array}$} \\
\hline \multirow{3}{*}{\multicolumn{2}{|c|}{$\begin{array}{c}\text { National Technical Information Service } \\
\text { United States Department of Commerce } \\
5285 \text { Port Royal Road } \\
\text { Springfield, Virginia } 22161\end{array}$}} \\
\hline & \\
\hline & \\
\hline \multirow{2}{*}{\multicolumn{2}{|c|}{$\begin{array}{l}\text { NTIS Price Codes } \\
\text { Microfiche A01 }\end{array}$}} \\
\hline & \\
\hline \multicolumn{2}{|c|}{ Printed Copy } \\
\hline & Price \\
\hline Pages & Codes \\
\hline $001-025$ & $\mathrm{~A} 02$ \\
\hline 026-050 & $\mathrm{A} 03$ \\
\hline $051-075$ & A04 \\
\hline $076-100$ & A05 \\
\hline $101-125$ & A06 \\
\hline $126-150$ & A07 \\
\hline $151-175$ & A08 \\
\hline $176-200$ & A09 \\
\hline $201-225$ & A010 \\
\hline $226-250$ & A011 \\
\hline $251-275$ & A012 \\
\hline $276-300$ & A013 \\
\hline
\end{tabular}


PNL -6073

UC -70

DEVELOPMENT OF A CONTINUOUS LIQUIO-FEO

LABORATORY-SCALE MINI-MELTER FOR

NUCLEAR WASTE GLASS DEVELOPMENT

M. A. H. Reimus

S. C. Marschman

G. L. Graff

February 1987

Prepared for

the U.S. Department of Energy

under Contract DE-ACO6-76RLO 1830

Pacific Northwest Laboratory

Richland, Washington 99352 


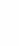

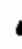


$\underline{\text { SUMMARY }}$

Borosilicate glass waste forms are being developed for solidifying exist. ing liquid high-level wastes in the United States. The waste glass will be produced in a liquid-fed, ceramic-lined melter by processing a slurry feed containing wastes and glass-forming chemicals. Physical properties of glasses can be predicted with reasonable accuracy, but in many cases meiting behavior cannot. Thus, defining an acceptable glass remains largely a trial and error effort. The testing of waste glass feed slurries in continuous melters that are large enough to provide representative data has typically required a onetenth scale or larger system, which is expensive and time consuming to operate, especially if real radioactive wastes are used. Significant effort has therefore been devoted to developing iaboratory screening tests that can identify unacceptable compositions before further resources are committed.

A smal1, continuous liquid-fed mini-melter (LFMM) has been developed at Pacific Northwest Laboratory (PNL) to aid in waste glass feed slurry development. The LFMM offers several advantages over testing in large-scale melters. The LFMM requires little lead time in preparing for a test run, and the labor and material requirements are low. Real-time melting behavior of liquid feed slurries can be investigated, and feed rates can be estimated for larger-scale melters. The glass produced is representative of that produced by a largerscale melter, as well as representative of the processing operation itself. Glass produced by the LFMM may subsequently be analyzed for metallic and other secondary phase formation. In contrast to larger-scale melters, the LFMM may be easily and inexpensively installed in a hot cell because of its relatively small size and simple configuration, enabling testing of radioactive feeds.

A total of six LFMM experimental runs were performed. Feeds were obtained which corresponded to PNL melter runs performed in larger PNL developmental joule-heated research melters. These nonradioactive liquid-fed ceramic melters are known as the High-Bay Ceramic Melter (HBCM), the Experimental Ceramic Melter (ECM), and the Pilot-Scale Ceramic Melter (PSCM). Preliminary results obtained with the limited testing are promising. Feeds processed in the LFMM exhibited behavior closely resembling that observed in the large-scale melters. 
Feed rate correlations between the LFMM and ECM, HBCM, and PSCM were developed to estimate a range of expected feed rates for the Targe-scale melters from LFMM data. More developmental work with LFMM testing needs to be completed. Further testing will eliminate bias and establish the LFMM's true correlation to, and representation of, large-scale melters. 


\section{ACKNOWLEDGMENTS}

The authors would like to thank Ron Stevens for his technical assistance with the furnace and crucible design. Frank Hara and coworkers performed the ICP analysis, and Jim Coleman performed the SEM/EDX analysis. Roy Bunnell provided a peer review of this report. The editorial support of Andrea Currie and the assistance of the Pacific Northwest Laboratory word processing and graphics staff were much appreciated. This report was prepared under the U.S. Department of Energy's Nuclear Waste Treatment Program at the Pacific Northwest Laboratory. Programmatic guidance was provided by Rick Brouns and Harry Burkholder. 


$$
\text { - }
$$




\section{CONTENTS}

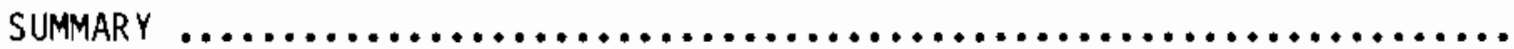

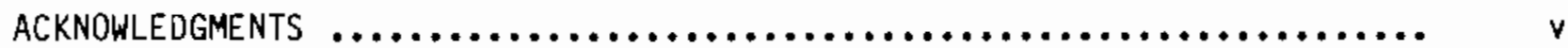

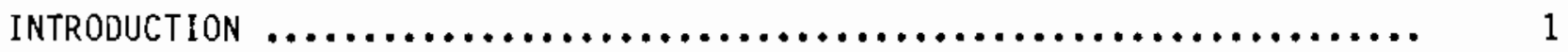

CONCLUSIONS AND RECOMMENDATIONS $\ldots \ldots \ldots \ldots \ldots \ldots \ldots \ldots \ldots \ldots \ldots \ldots \ldots \ldots \ldots$

MELTER SYSTEM DESIGN $\ldots \ldots \ldots \ldots \ldots \ldots \ldots \ldots \ldots \ldots \ldots \ldots \ldots \ldots \ldots \ldots \ldots \ldots \ldots \ldots \ldots$

FEED SYSTEM $\ldots \ldots \ldots \ldots \ldots \ldots \ldots \ldots \ldots \ldots \ldots \ldots \ldots \ldots \ldots \ldots \ldots \ldots \ldots \ldots \ldots \ldots \ldots$

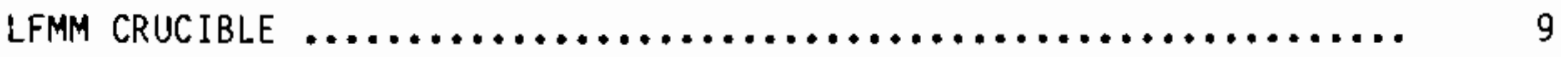

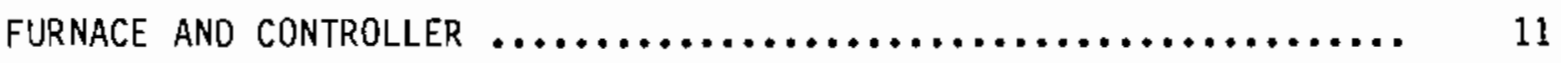

MELTER TEST PROCEDURE $\ldots \ldots \ldots \ldots \ldots \ldots \ldots \ldots \ldots \ldots \ldots \ldots \ldots \ldots \ldots \ldots \ldots \ldots \ldots \ldots \ldots . \ldots \ldots$

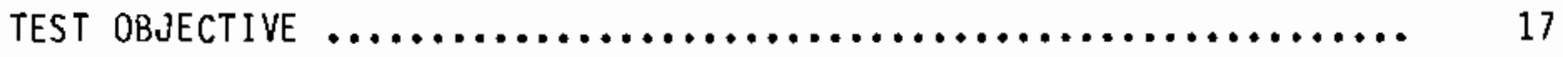

NOMINAL AND MAXIMUM FEED RATE DETERMINATION $\ldots \ldots \ldots \ldots \ldots \ldots \ldots \ldots \ldots . \ldots \ldots$

MELT SURFACE AND GLASS PRODUCT EXAMINATIDNS ............... 18

FEED RATE AND COLD CAP FORMATION RESULTS $\ldots \ldots \ldots \ldots \ldots \ldots \ldots \ldots \ldots \ldots \ldots \ldots \ldots$

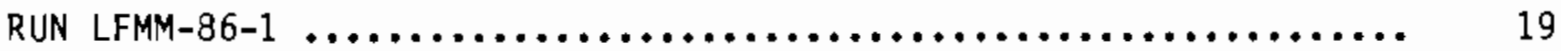

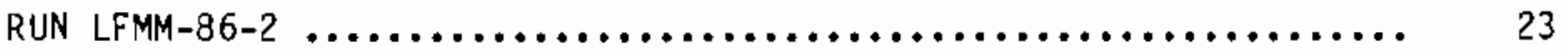

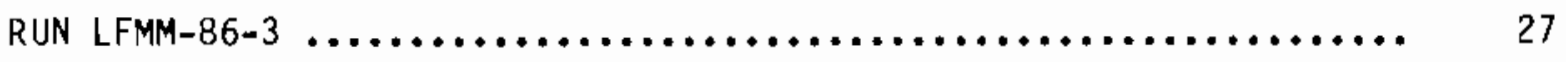

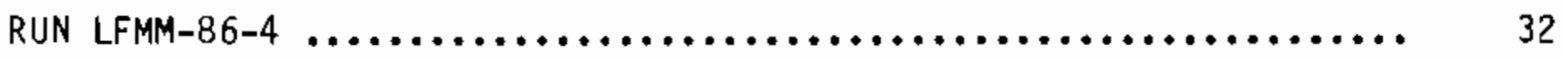

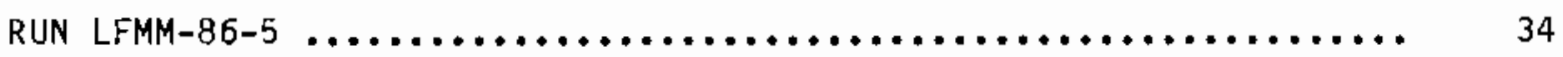

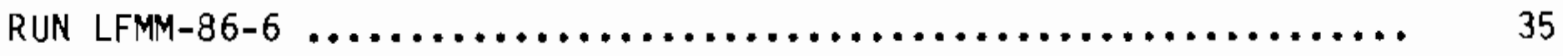

FEED RATE CORRELATIONS $\ldots \ldots \ldots \ldots \ldots \ldots \ldots \ldots \ldots \ldots \ldots \ldots \ldots \ldots \ldots \ldots \ldots \ldots . \ldots \ldots \ldots$

MAXIMUM FEED RATE CORRELATIONS $\ldots \ldots \ldots \ldots \ldots \ldots \ldots \ldots \ldots \ldots \ldots \ldots \ldots \ldots . \ldots \ldots$

NOMINAL FEED RATE CDRRELATIONS $\ldots \ldots \ldots \ldots \ldots \ldots \ldots \ldots \ldots \ldots \ldots \ldots \ldots \ldots \ldots . \ldots \ldots$

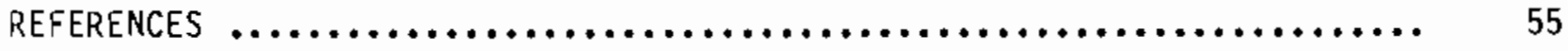

APPENDIX - LFMM FEED COMPOSITIONS AND FEED AND GLASS ANALYSES ........ A.1 
1 Experimental Apparatus - Overall Schematic .................... 8

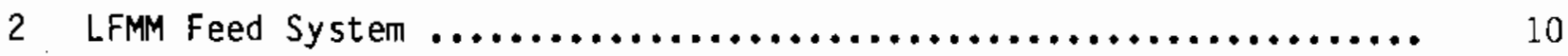

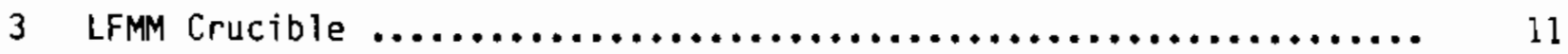

4 LFMM Crucible $\ldots \ldots \ldots \ldots \ldots \ldots \ldots \ldots \ldots \ldots \ldots \ldots \ldots \ldots \ldots \ldots \ldots, 12$

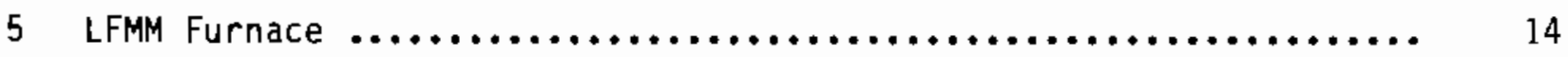

6 LFMM Furnace Specifications and Dimensions $\ldots \ldots \ldots \ldots \ldots \ldots \ldots . . . \ldots 15$

7 Redox Response of LFMM-86-1 Glass $\ldots \ldots \ldots \ldots \ldots \ldots \ldots \ldots \ldots \ldots \ldots \ldots$ in

8 SEM Micrograph of LFMM-86-1 Glass Sample No. $5 \ldots \ldots \ldots \ldots \ldots \ldots . . .22$

9 EDX Spectra of Feature 1 in Figure $8 \ldots \ldots \ldots \ldots \ldots \ldots \ldots \ldots \ldots \ldots$ z2

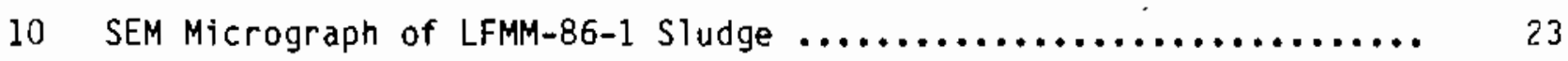

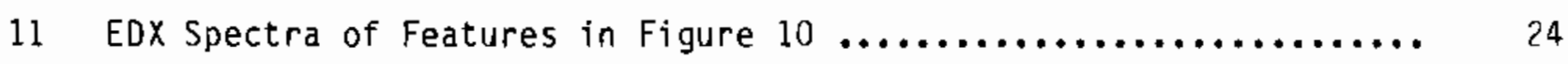

12 Change in 0xide Composition of LFMM-86-2 Output Glass ........... 26

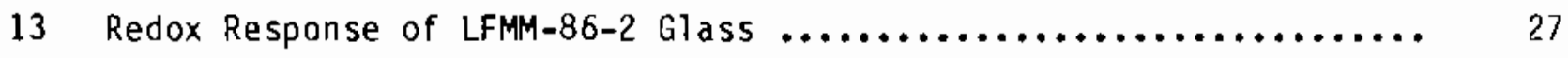

14 SEM Micrograph of LFMM-86-2 Glass Sample No. $5 \ldots \ldots \ldots \ldots \ldots \ldots . . .28$

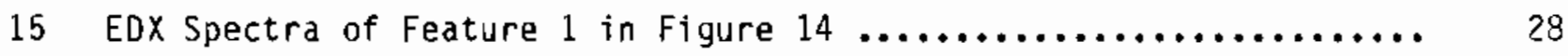

16 Change in 0xide Composition of LFMM-86-3 Output Glass ........... 30

17 SEM Micrograph of LFMM-86-3 Glass Sample No. $5 \ldots \ldots \ldots \ldots \ldots \ldots . . . \ldots 31$

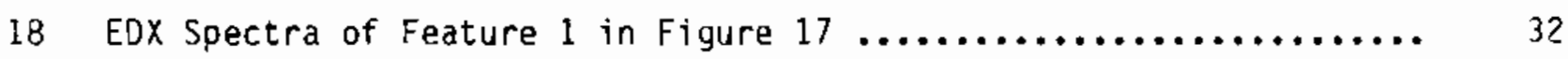

19 Change in Oxide Composition of LFMM-86-5 Output Glass ........... 36

20 Time Distribution of $\mathrm{B}_{2} \mathrm{O}_{3}$ in LFMM-86-5: Comparison with

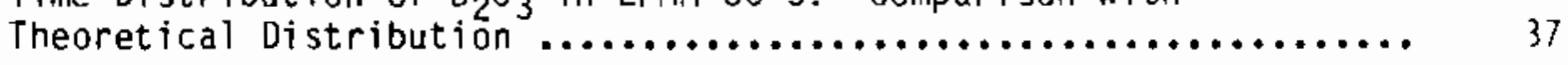

21 SEM Micrograph of LFMM-86-5 Cold Cap Interface $\ldots \ldots \ldots \ldots \ldots \ldots \ldots . . . \ldots$

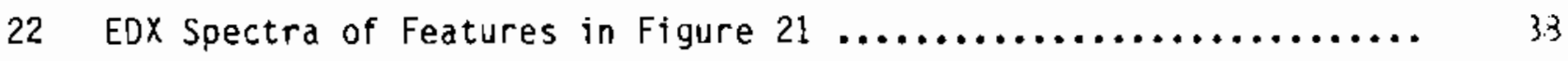

23 SEM Micrograph of LFMM-86-5 Cold Cap $\ldots \ldots \ldots \ldots \ldots \ldots \ldots \ldots \ldots \ldots . . . \ldots \ldots$

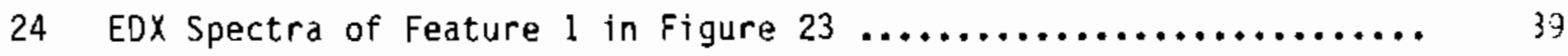


25 SEM Micrograph of LFMM-86-5 Output Glass .................. 40

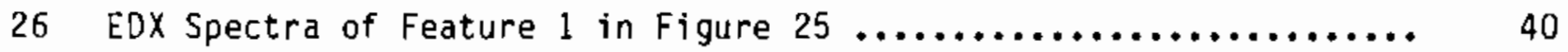

27 Redox Response of LFMM-86-6 Glass ........................ 42

28 SEM Micrograph of LFMM-86-6 Cold Cap Interface $\ldots \ldots \ldots \ldots \ldots \ldots \ldots . . \ldots$

29 EDX Spectra of Features in Figure $28 \ldots \ldots \ldots \ldots \ldots \ldots \ldots \ldots \ldots \ldots . \ldots . \ldots$

30 SEM Micrograph of LFMM-86-6 Cold Cap ..................... 45

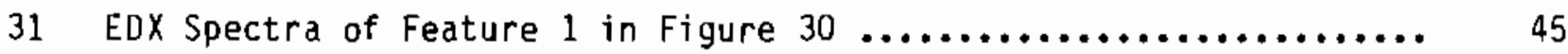

32 SEM Micrograph of LFMM-86-6 Output Glass ................... 46

33 EDX Spectra of Feature 1 in Figure $32 \ldots \ldots \ldots \ldots \ldots \ldots \ldots \ldots \ldots . \ldots . \ldots . \ldots$

34 Maximum Feed Rate Correlations Between the PSCM/HBCM and 48

35 Normalized Maximum Feed Rates Achieved by Melters ............. 49

36 Nominal Feed Rate Correlations Between the ECM, HBCM, PSCM and the LFMM ...................................... 51

37 Normalized Nominal Feed Rates Achieved by Melters .............. 54 


\section{TABLES}

1 Comparison of Liquid-Fed Mini-Melter and PNL Larger-Scale

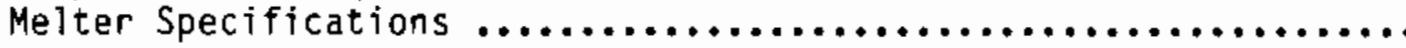

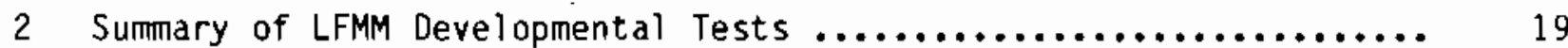

3 LFMM-86-1 Run Conditions and ResuTts $\ldots \ldots \ldots \ldots \ldots \ldots \ldots \ldots \ldots . . . . . . .20$

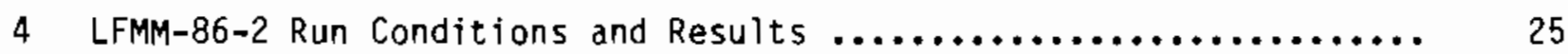

5 LFMM-86-3 Run Conditions and Results ...................... 29

6 LFMM-86-4 Run Conditions and Results ....................... 33

7 LFMM-86-5 Run Conditions and Results $\ldots \ldots \ldots \ldots \ldots \ldots \ldots \ldots \ldots \ldots . \ldots \ldots$

8 LFMM-86-6 Run Conditions and Results $\ldots \ldots \ldots \ldots \ldots \ldots \ldots \ldots \ldots \ldots$, 11

9 Maximum Feed Rates Achieved by Melters with Feeds Run in

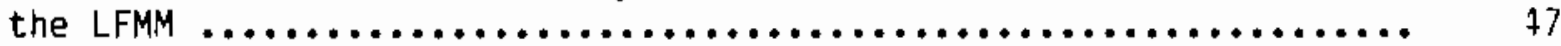

10 Maximum Feed Rate Correlations with LFMM $\ldots \ldots \ldots \ldots \ldots \ldots \ldots \ldots . . . \ldots$

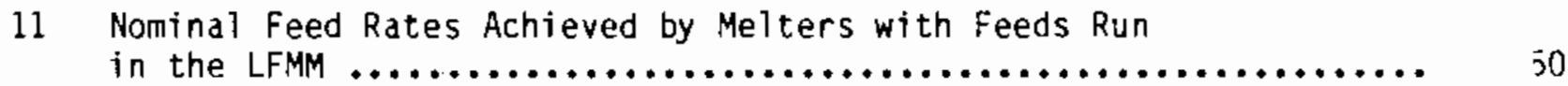

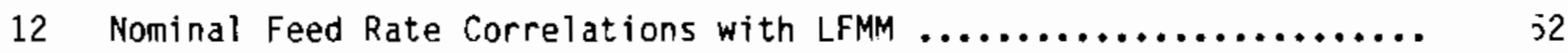

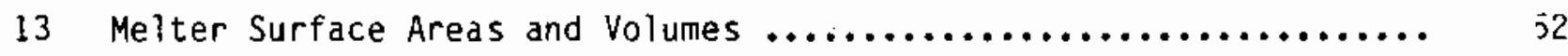




\section{DEVELOPMENT OF A CONTINUDUS LIQUID-FED LABORATORY-SCALE \\ MINI -MELTER FOR NUCLEAR WASTE GLASS DEVELOPMENT}

\section{INTRODUCTION}

Several waste forms have been proposed for the permanent containment of radioactive nuclear waste. These include grout, SYNROC (synthetic rock forms), and borosilicate glass (U.S. DOE 1982). Borosilicate glass has been selected as the reference waste form to be used in the containment of high-level radioactive nuclear wastes (Harmon, Lakey, and Leigh 1984). Borosilicate glasses may be produced by a variety of systems, one of which is the continuous liquidfed joule-heated ceramic melter. Typically, radioactive nuclear waste and glass formers are mixed to produce a liquid slurry. This slurry is continuously fed into the melter where an electric current is passed through molten glass; the liquid in the slurry evaporates, and the resulting solids melt, forming a glass. The glass continuously discharges into specially designed canisters for permanent storage (Westsik et al. 1985).

Because no two nuclear waste sources are identical in composition, different glass compositions must be developed to accommodate each waste source, to ensure safe containment of the waste and efficient processing of the glass. Development of waste glass compositions is both time-consuming and costly. Glass must be processable and must provide good containment of radionuclides. Once a glass composition is developed, a feed slurry must be developed to process it. Each feed slurry composition must be tested at various levels of scale to determine its melting rate and melting behavior. The time and effort necessary to determine the processability of waste glass feeds in full-scale melters have been reduced somewhat by the development of several smaller-scale melters that permit feeds to be tested for processability before they are used in large-scale equipment. Such equipment includes the 8.2-1iter Experimental Ceramic Melter (ECM) and the 50-liter High-Bay Ceramic Melter (HBCM) developed at Pacific Northwest Laboratory (PNL); a small-capacity (1-liter) dry-fed joule-heated melter (Plodinec and Chismar 1979) developed at Savannah River 
Laboratory (SRL); and a 1-liter-capacity dry-fed joule-heated melter developed by Allied Chemical Corporation, Idaho Falls (Gombert 1979).

Efforts at PNL to provide melting behavior support to large-scale melter operations resulted in the development of a bottom-heated refractory crucible test during 1985 (Goldman 1985; Goldman, Chick, and Blair 1985). This test provides a means for investigating the melting rate and melting behavior of a glass feed slurry. Often during melting of a feed slurry, a thick, impermeable cold cap may develop. The cold cap impedes heat transfer to the feed, slowing the melting process. The cold cap may also trap gas between its bottom and the melt surface, further impairing heat transfer. Melting rates of candidate feed slurries are determined by melting a small, amount of feed slurry in a bottomheated refractory crucible. The crucibles are held in a furnace at temperatire and extracted as a function of time. The crucibles are sectioned, and the amount of cold cap is measured and converted to a melting rate. While this method has proven satisfactory for determining melting rates of some glass feeds, accurate results for feeds that produce thin, frail cold caps cannot be obtained. Also, long-term effects of melter operation such as melter surface residue layers and formation of secondary metallic and other phases cannot be evaluated with the bottom-heated crucible test.

The effort to address actual time-dependent melter problems resulted in the design and construction of the liquid-fed mini-melter (LFMM). The LFMM offers several advantages over the bottom-heated crucible tests. The LFMM is a continuously-fed, externally heated melter, with a $300-\mathrm{cm}^{3}$ volume. Melting behaviors of glass feed slurries can be directly monitored, and feed rates can be directly determined. Information on all types of liquid feed slurries can be obtained regardless of the melting behavior and cold cap generated by the feed slurry. Glass produced by the melter can also be examined for metallic and other secondary phase formation. Thus, the LFMM should more truly represent large-scale melters.

This report documents the development of the LFMM and its use in testing simulated nuclear waste glass feed slurries. This work was conducted at PNL in support of the Nuciear Waste Treatment Program (NWTP). Correlations between the LFMM and the ECM, HBCM, and PSCM are presented. The LFMM has been shown to 
be a useful tool for the development of nuclear waste glass slurry feed compositions, and will result in the savings of time and finances associated with waste glass development. 

CONCLUSIONS AND RECOMMENDATIONS

The LFMM is proving itself to be a useful tool in liquid slurry melter feed development. Feeds processed by the LFMM exhibited behavior very closely resembling that seen in the engineering-scale melters. Feeds that had processed well in the engineering-scale melters also processed well in the LFMM. Feeds that processed poorly in engineering-scale melters also processed poorly in the LFMM. The cold caps and melt surfaces observed in the LFMM resembled those seen in engineering-scale melters. The glass product produced had similar crystalline content.

Feed rate correlations developed between the LFMM and engineering-scale melters can be used to estimate a range of expected feed rates. Correlations developed using maximum feed rates had better fit than those developed using nominal feed rates.

More development work with LFMM testing needs to be completed. Other feeds previously run in engineering-scale melters should be tested in the LFMM. As foaming incidents were not experienced in the LFMM, feed that has exhibited foaming behavior in other melters should be run in the LFMM. Testing other feeds will add to establishing LFMM correlations. In addition, feeds not previously run in engineering-scale melters should be "screened" by the LFMM. This testing will eliminate bias and establish the LFMM's true correlation to, and representation of, large-scale melters. 



\section{MELTER SYSTEM DESIGN}

The LFMM was designed as a laboratory-scale melter, to be representative of engineering- and large-scale ceramic melters with respect to melting behavior. The apparatus incorporates basic components of the large-scale melters: a feed agitation tank, slurry pumping and feeding system, melting compartment, heat source, and glass discharge outlet. The large-scale melters are joule-heated while the LFMM is externally heated. Because of the LFMM's small size, joule heating was judged unnecessary. Heat transfer is high enough that the temperature in the melter would be relatively uniform regardless of heating method. External heat applied to the melting chamber walls is rapidiy transferred to the melt, thus minimizing effects on the melt cold cap. The system is designed to allow continuous feeding of liquid slurry, with constant processing of molten glass. An overall schematic of the LFMM system is shown in Figure 1. The three major components of the LFMM--the feed system, crucible, and furnace and controller--are described in detail in the following subsections. The design specifications of the LFMM are compared in Table 1 with those of the PNL developmental joule-heated melters.

\section{FEED SYSTEM}

The primary component of the LFMM slurry feed system is the Gilson Minipuls 2 peristaltic pump. This unit is currently capable of producing linear flow rates of approximately 1 to $14 \mathrm{~mL} / \mathrm{min}$ of water. A manifold pump tube rated at $3.90 \mathrm{cc} / \mathrm{min}$ connected to $3 / 32-\mathrm{in}$. - ID $\times$ 5/32-in. $-0 \mathrm{D}$ Tygon R-3603 tubing comprises the feed line. The diameter of this tubing was found to be sufficient in generating linear velocities high enough at a minimum volumetric flow rate of $2 \mathrm{~mL} / \mathrm{min}$ to produce enough inline turbulence to prevent inline feed separation. The liquid feed slurry is drawn from a 1000-mL Erlenmeyer flask. The feed is kept homogeneous and in suspension by continuous agitation by a high speed mixer. The slurry is pumped to the top opening of the furnace and dripped into the LFMM crucible. The system is pictured in figure 2. 


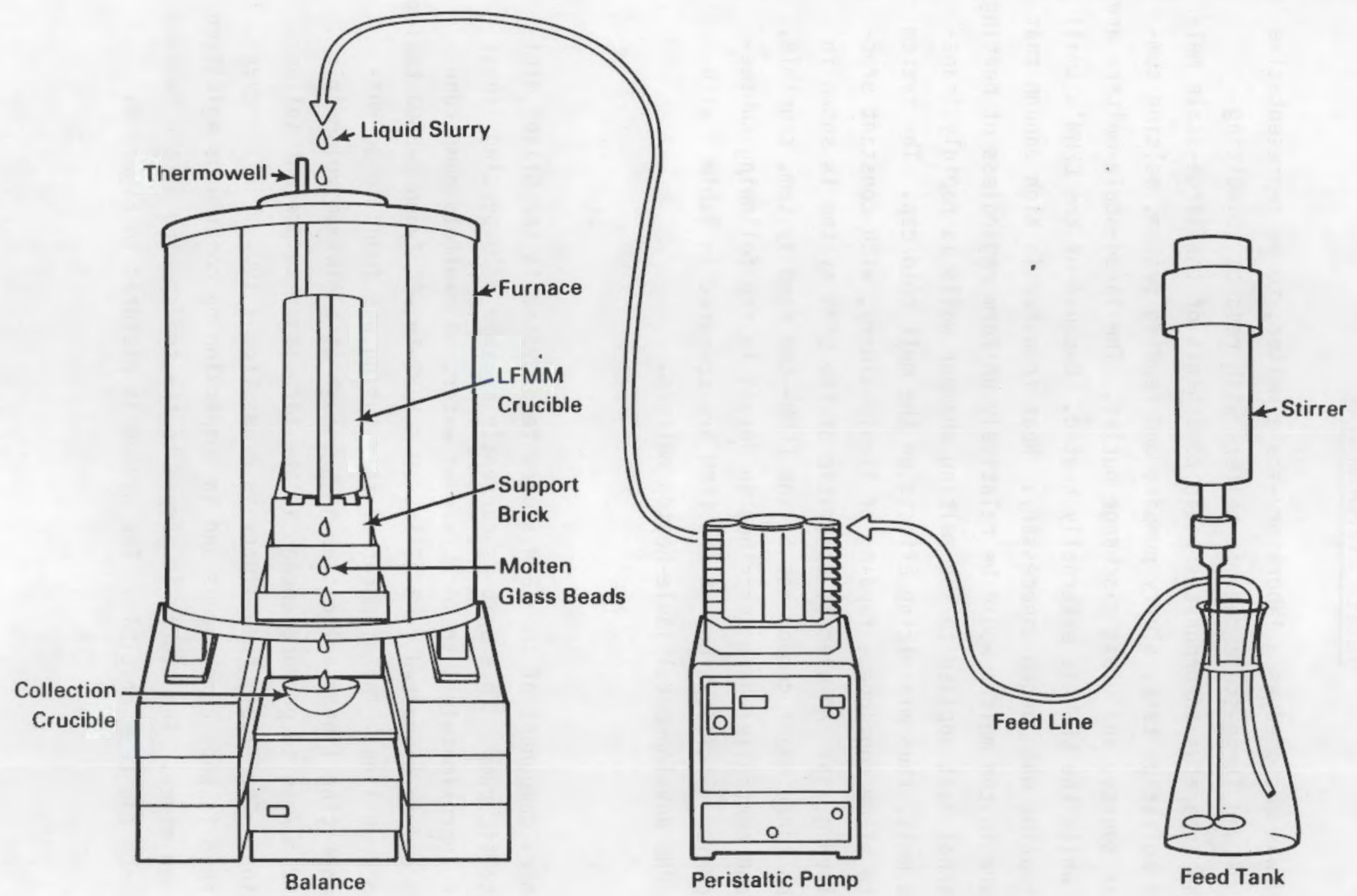

FIGURE 1. Experimental Apparatus - Overall Schematic 
TABLE 1. Comparison of Liquid-Fed Mini-Melter and PNL

Larger-Scale Melter Specifications

\begin{tabular}{|c|c|c|c|c|}
\hline & \multicolumn{4}{|c|}{ Melter } \\
\hline & LFMM & $\mathrm{ECM}$ & $\mathrm{HBCM}$ & PSCM \\
\hline Surface area, $\mathrm{m}^{2}$ & 0.0029 & 0.054 & 0.25 & 0.73 \\
\hline Volume, L & 0.31 & 8.2 & 50 & 290 \\
\hline $\begin{array}{l}\text { Surface area-to- } \\
\text { volume ratio, } \mathrm{m}^{-1}\end{array}$ & 9.4 & 6.6 & 5.0 & 2.5 \\
\hline Glass depth, cm & 10.6 & 15 & 22 & 42 \\
\hline
\end{tabular}

LFMM CRUCIBLE

The LFMM crucible is constructed of Inconel and incorporates several unique design features indicated in Figures 3 and 4 . First is the curved weir, or partition, which runs vertically $1 / 2 \mathrm{in}$. from the bottom of the crucible, extending to the top. This allows the melting chamber to remain isolated from the exit glass compartment. Melted, homogeneous glass travels under the weir from the melting chamber and up toward the exit tube opening in the side of the crucible.

Once the molten glass within the crucible reaches a depth of $4 \mathrm{in.}$, the molten material will exit the crucible through a $1 / 4-i n$. hole drilled in the side and will travel down the $3 / 8-i n .-0 D$ exit tube. The exit tube, designed as an overflow device, extends approximately $3 / 8 \mathrm{in}$. below the bottom of the LFMM crucible, eliminating the problem of glass clinging to the metal surface while keeping the exit spout well within the heat zone of the furnace. In addition, the exit tube spout is beveled to facilitate the formation of clean glass droplets, which fall and exit the furnace through a 1-in. hole in the bottom. The glass output is collected in a crucible resting upon a Mettler Model 4400 toploading balance where the amount produced is weighed to determine production rate.

The operating temperature of the crucible and glass is measured using a Type $K$ thermocouple placed inside an Inconel thermowell. The thermowell is inserted through the top insulating plug of the furnace and into the molten glass, and rests upon the crucible bottom. A vertical temperature profile of 


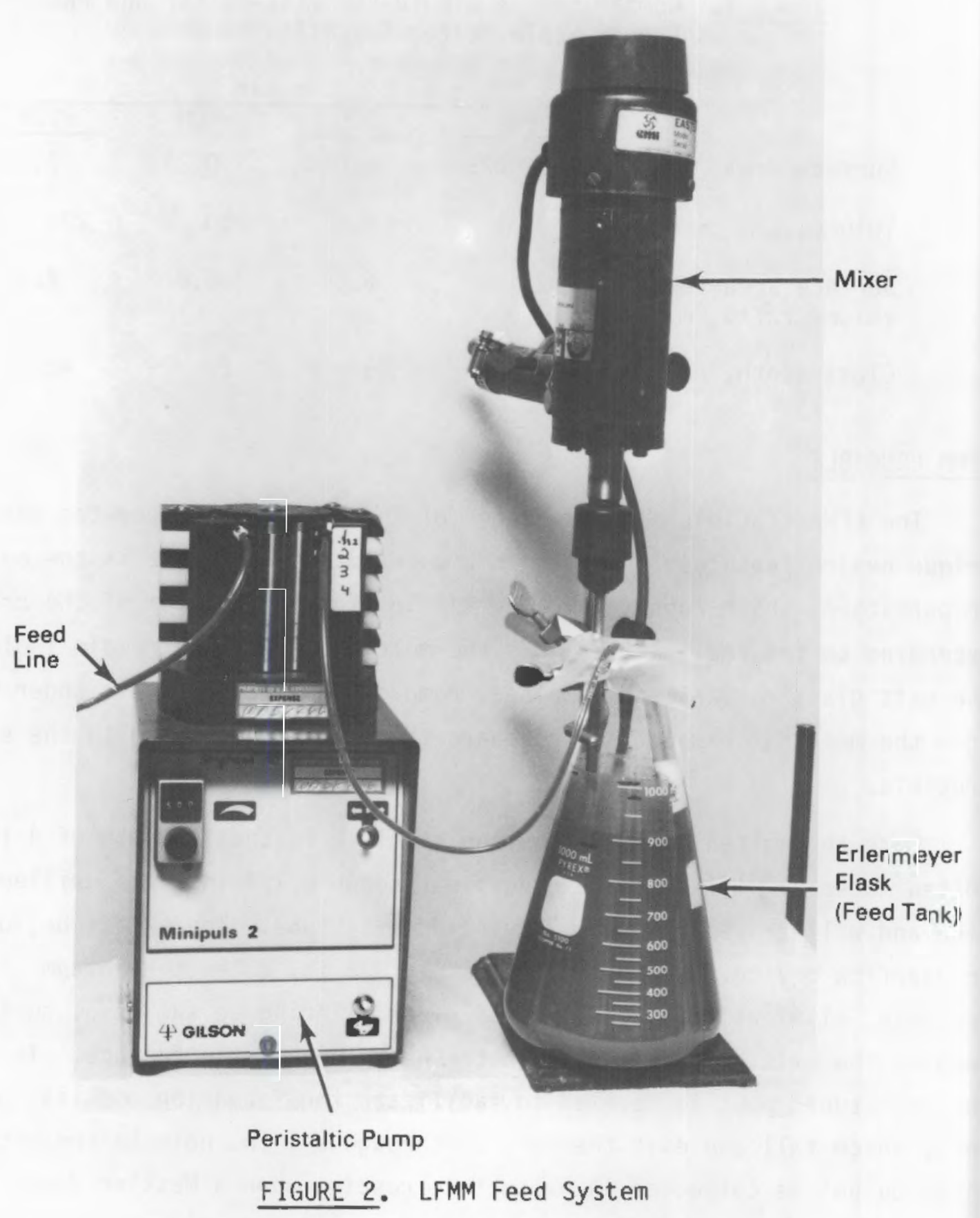

the melt may be taken by placing a Type $K$ thermocouple directly into the molten glass and measuring the temperature at specified depths. Temperature measurements taken immediately prior to feeding are typically 1120 to $1135^{\circ} \mathrm{C}$ at the bottom of the crucible and 1135 to $1150^{\circ} \mathrm{C}$ at the melt surface; the average 

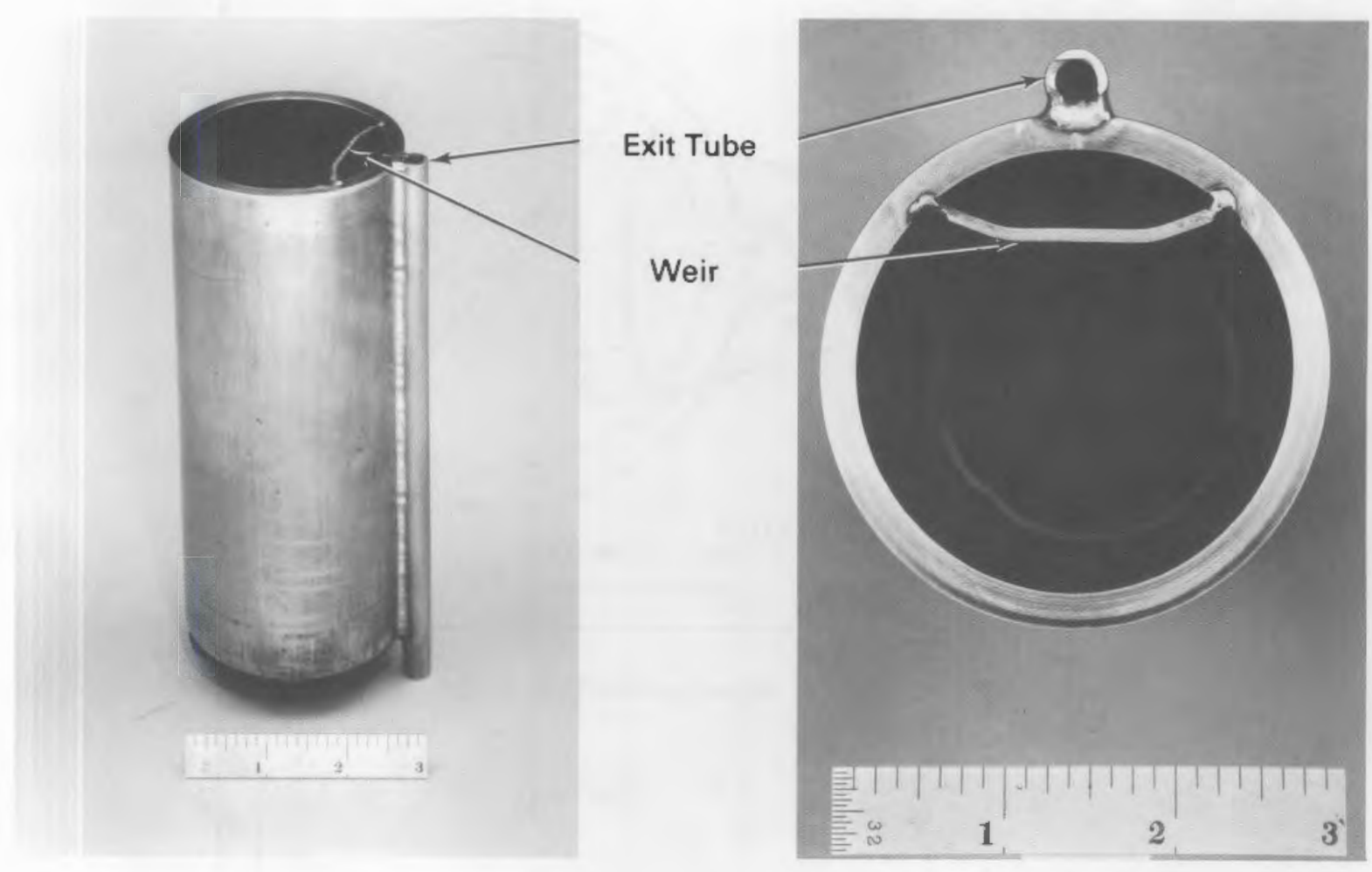

FIGURE 3. LFMM Crucible

temperature differential is $15^{\circ} \mathrm{C}$. Temperature measurements taken during slurry feeding are typically 1120 to $1135^{\circ} \mathrm{C}$ at the bottom of the crucible and 980 to $1010^{\circ} \mathrm{C}$ at the melt surface, giving an average temperature differential of 110 to $130^{\circ} \mathrm{C}$. Larger-scale joule-heated PNL developmental melters typically run with bulk glass temperatures of 1130 to $1150^{\circ} \mathrm{C}$, with surface temperatures 50 to $100^{\circ} \mathrm{C}$ lower.

\section{FURNACE AND CONTROLLER}

The LFMM crucible is heated to operating temperature in a Thermcraft Model 35-11-1ZV-CR resistance-heated tube furnace equipped with heavy-gauge Kanthal Al heating elements capable of generating operating temperatures up to $1300^{\circ} \mathrm{C}$. The furnace is controlled by the Thermcraft Temperature Control System, Model 600-208-20-S-D-T, consisting of 1) the RKC Model REX C1000 Type S microprocessor-based temperature controller, 2) an SCR power controller, and 3) a step-down transformer. The REX Cl000 controller supplies a linear 4- to 20-mV output signal to the power controller. In addition, an Omega Model 6102 Type S 


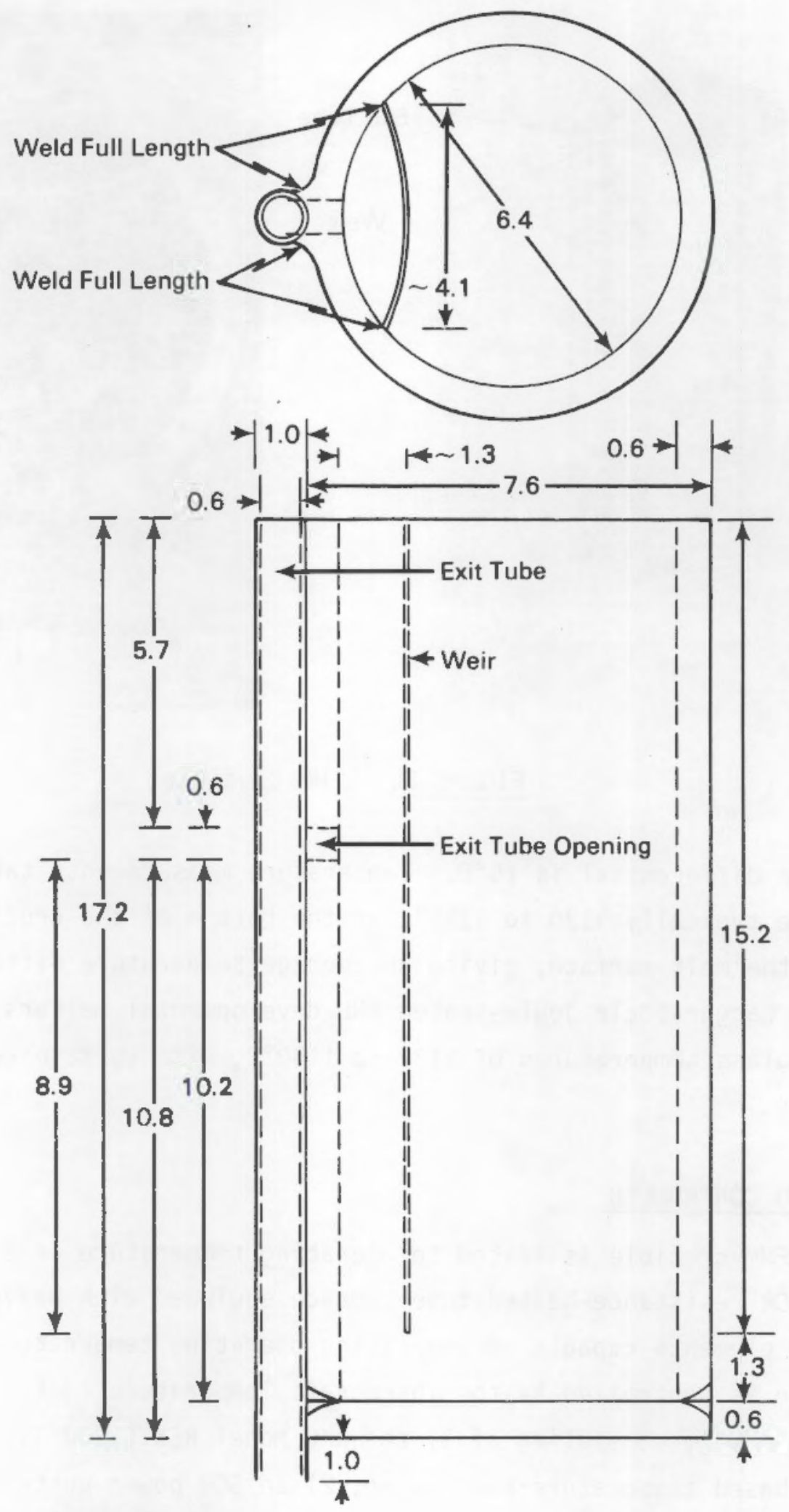

All Dimensions in $\mathrm{cm}$

FIGURE 4. LFMM Crucible 
controller is used as an overtemperature controller and operated by a thermocouple separate from the main control thermocouple. This backup system protects against failures of the primary control system. The furnace is pictured in Figure 5. Figure 6 provides the specifications and dimensions of the LFMM furnace.

The LFMM crucible is located inside the furnace such that the midpoint of the molten glass in the crucible is at the midpoint of the furnace heating zone. A l-in. hole was cut in the top and bottom insulating plugs to allow continuous feeding of glass slurry into, and output of molten glass from, the furnace. 


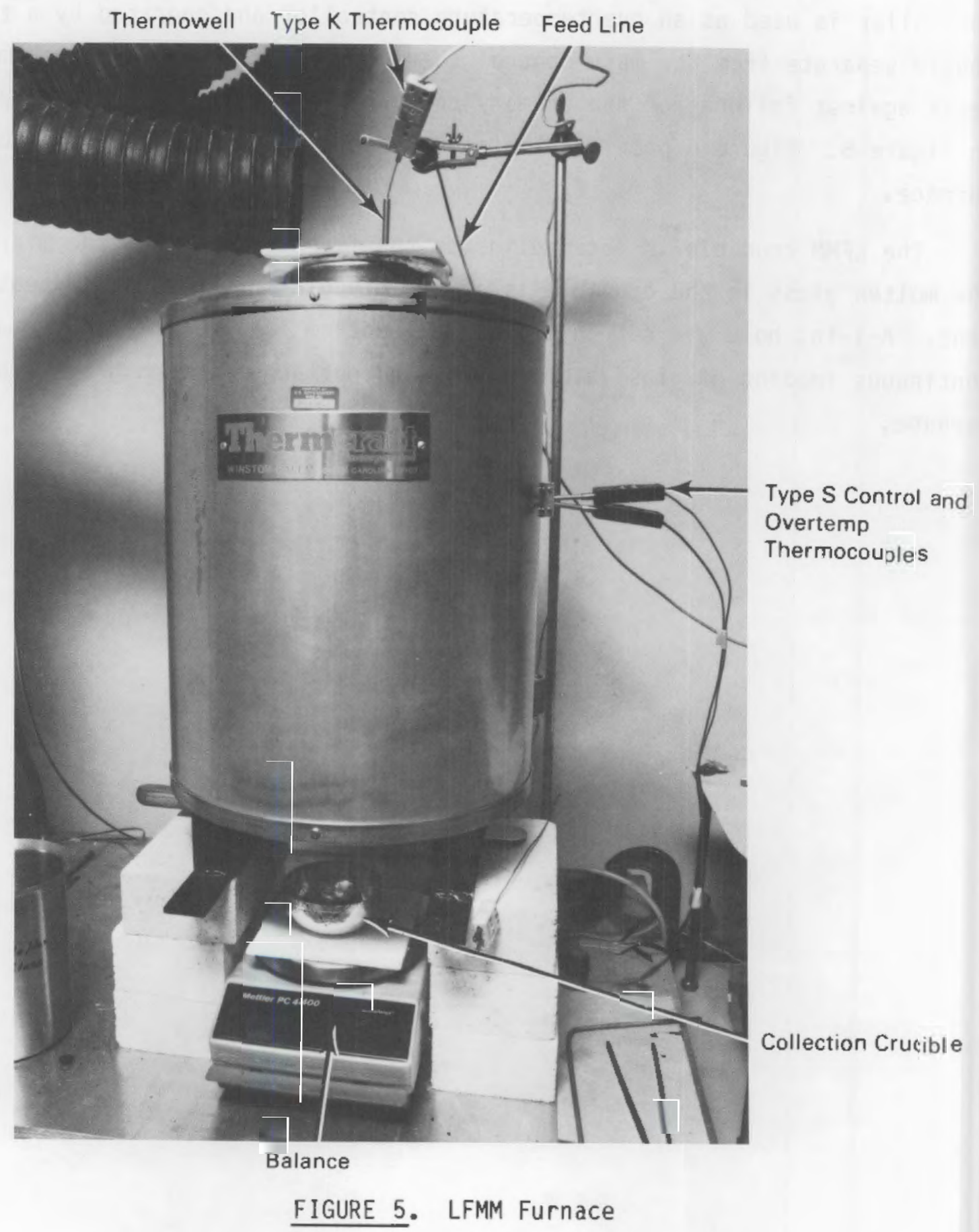




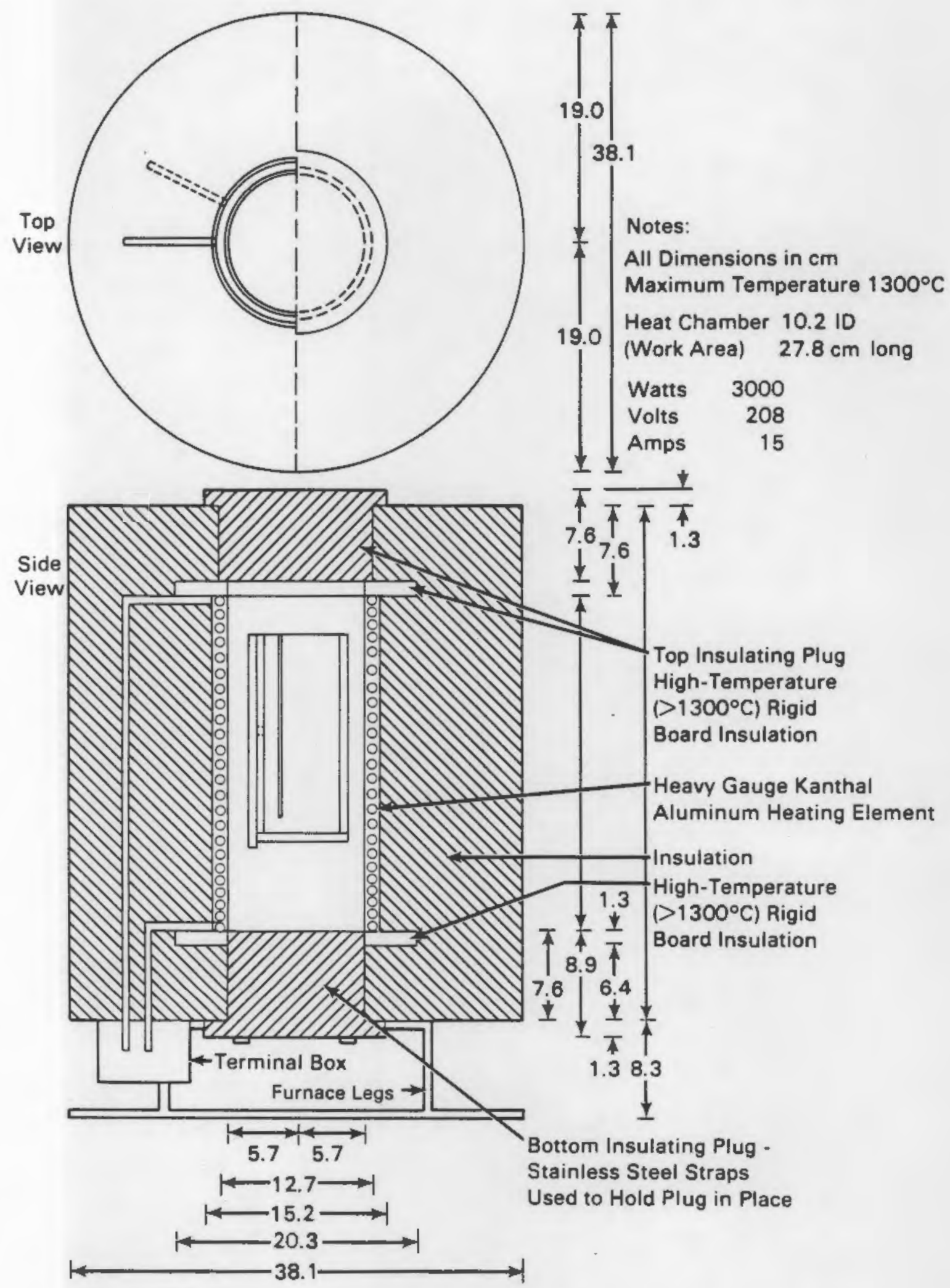

FIGURE 6. LFMM Furnace Specifications and Dimensions 



\section{MELTER TEST PROCEDURE}

In this section, the melter test objective is presented. Procedures used to determine feed rates and to examine melt surfaces and glass products are explained.

\section{TEST OBJECTIVE}

The overall LFMM test objective is to ultimately provide melting behavior data to be used in liquid slurry melter feed development. During actual largescale melter operations, the LFMM could be used as a testing system for variations in melter feeds. The LFMM could also be easily installed in a hot cell because it is small, inexpensive, and simply configured. Melting/feed rate and cold cap formation data, including secondary phase formation and melt foaming, are of primary importance. These properties are used to determine whether or not a liquid slurry feed has acceptable processing characteristics for continuous ceramic melter processing. Maximum and nominal feed rates give indications of how the feed will process in larger-scale melters. Foaming and secondary phase formation potentially reduce processing rates by interfering with surface melting. Secondary phase formation, if soluble in an aqueous environment, can also potentially compromise the chemical durability of the glass product. Conductive higher-density secondary phases can also settle and cause a short circuit in joule-heated ceramic melters. Early observation of these melting behaviors can be used to correct the situation before a feed is tested in large-scale processing equipment.

NOMINAL AND MAXIMUM FEED RATE DETERMINATION

A nominal melter feed rate is defined here as a feed rate that produces 75 to $80 \%$ cold cap coverage of the melt surface area. Active venting should occur around the cap, and ideally through it. This feed rate may be referred to as the "operating" or "design" feed rate. A maximum melter feed rate produces up to $95 \%$ cold cap coverage, with active venting. This is the maximum feed rate that can be achieved without flooding the melter. 
During the melter runs, the feed rate was changed by adjusting the pump setting. The volumetric feed rate was determined by measurements taken at the feed inlet (volume collected over $1 \mathrm{~min}$.). A given feed rate was run for 1 to $2 \mathrm{~h}$ before it was adjusted up or down. The appearance of the melt surface was used to determine whether further adjustments of the feed rate were necessary to obtain nominal or maximum feeding conditions. The definitions of nominal and maximum feed rates were used as guidelines, not as strict operating requirements. Observation of both the melt surface and cold cap coverage was taken into account.

\section{MELT SURFACE AND GLASS PRODUCT EXAMINATIONS}

The melt surface was examined for secondary phase formation, melt foaming, and cold cap shape and formation. As noted earlier, secondary phase formation can affect both processability and product quality. Melt foaming also hinders processability. The cold cap shape and formation is important to observe, as the formation may interfere with processing. Based on work done by B. M. Wise and J. M. Perez of PNL in 1985, cold caps have been observed to not spread out on the melt surface area, thereby melting more slowly than under ideal conditions. Thus, the melt surface was visually observed frequently, and its appearance was noted.

To characterize the glass product produced by the LFMM, samples of the output glass were taken fairly frequently. The samples were submitted for chemical analysis by inductively coupled plasma spectroscopy (ICP). The analyses were used to provide indications of melter mixing characteristics and confirm calculated turnover times. Thin sections made from samples taken of glass produced by the melter after at least one turnover time were examined using optical microscopy and scanning electron microscopy/energy dispersive $X$-ray (SEM/EDX) analysis for crystal and secondary phase identification. 


\section{FEED RATE AND COLD CAP FORMATION RESULTS}

The objectives of the first liquid-fed mini-melter runs were to gain operating experience, develop operating procedures, and generate data for developing empirical correlations between the LFMM and PNL larger-scale developmental melters. Of primary importance were melting/feed rate and cold cap formation (including secondary phase formation and melt foaming). These properties are used to determine whether or not a given liquid slurry feed has acceptable processing characteristics for continuous ceramic melter processing.

Maximum and nominal feed rates were determined for each of six runs, designated LFMM-86-1 through LFMM-86-6. Prior to each run, the feed used was analyzed via ICP. Feed and glass samples were taken routinely during each run and submitted for ICP analysis. All feed compositions and feed and glass analyses are listed in the Appendix.

In this section, the experimental conditions and results obtained from each run are described and discussed. Table 2 summarizes the LFMM developmental tests.

TABLE 2. Summary of LFMM Developmental Tests

\begin{tabular}{|c|c|c|c|c|c|c|}
\hline \multirow[b]{2}{*}{ Varlable } & \multicolumn{5}{|c|}{ Run } & \multirow[b]{2}{*}{$86-6$} \\
\hline & $86-1$ & $86-2$ & $86-3$ & $86-4$ & $86-5$ & \\
\hline Feed & SRL-TDSF-131 & $\begin{array}{l}\text { PSCM-22 } \\
\text { (Aqed } 1 \text { yr) }\end{array}$ & $\mathrm{HBCM}-86-2$ & FRG 8 & WV 182 & WV 182 \\
\hline Reductant & Sugar & Sugar & $\begin{array}{l}\text { Formic } \\
\text { Acid }\end{array}$ & None & None & Sugar \\
\hline Melt Behavlor & Good & Poor & Good & Good & Poor & Poor \\
\hline Phase Formation & None & Spinel & Spinel & $\begin{array}{l}\text { Few } \\
\text { Crysta is }\end{array}$ & $\begin{array}{l}\text { Ca } \\
\text { Phosphate }\end{array}$ & $\begin{array}{l}\text { Ca } \\
\text { Phosphate }\end{array}$ \\
\hline Cold Cap & Spread Out & $\begin{array}{l}\text { "Tower" } \\
\text { Formation }\end{array}$ & $\begin{array}{l}\text { Spread } \\
\text { Out }\end{array}$ & $\begin{array}{l}\text { Sma II } \\
\text { "Tower" }\end{array}$ & $\begin{array}{l}\text { Thl ck } \\
\text { "Tower" }\end{array}$ & $\begin{array}{l}\text { Thlek } \\
\text { "Tower" }\end{array}$ \\
\hline
\end{tabular}

$\underline{\text { RUN LFMM-86-1 }}$

Experimental run LFMM-86-1 lasted $13 \mathrm{~h} 17 \mathrm{~min}$. Melter turnover (time for turnover of one melter volume) occurred in approximately $4.3 \mathrm{~h}$, based on mass 
of glass output. A total of 6.02 L of SRL-TDSF-131 feed (a) was processed, producing $2.66 \mathrm{~kg}$ of glass. This feed had been used in the HBCM during the HBCM-86-1 run (March 10 through 14, 1986). The same target composition had been run in the PSCM during PSCM-4 (December 7 through 11, 1981). Crushed glass from HBCM-86-1 was used to dry-feed the LFMM prior to slurry feeding. The conditions and results for run LFMM-86-1 are summarized in Table 3 .

The SRL-TDSF-131 feed processed very well in the LFMM. The molten glass showed no evidence of significant phase content, and it dripped cleanly from the crucible outlet tube. The cold cap spread out well, was flexible, and vented well. No melting problems were encountered.

Analyses of the feed samples taken during the run show no major deviations from the bulk composition of the feed. This indicates that minimal settling of the slurry components occurred in the feed lines.

Analyses of the glass samples taken show minor variation of the glass composition over time. The redox response of the glass over the run time is illustrated in Figure 7. The $\mathrm{Fe}^{2+} / \mathrm{Fe}^{3+}$ rose substantially after approximately $4 \mathrm{~h}$ into the run. This is caused by turnover of the reducing feed. The starting glass composition is reduced only slightly. As more feed is incorporated into the glass volume, the glass becomes more reduced. The jump occurs around the melter turnover time (approximately $5 \mathrm{~h}$ ).

\section{TABLE 3. LFMM-86-1 Run Conditions and Results}

$\begin{array}{ll}\text { Feed used } & \text { SRL-TDSF-131 } \\ \text { Total run time } & 13 \mathrm{~h} 17 \mathrm{~min} \\ \text { Amount of feed processed } & 6.02 \mathrm{~L} \\ \text { Amount of glass produced } & 2.66 \mathrm{~kg} \\ \text { Feed rate range } & 0.36 \text { to } 0.60 \mathrm{~L} / \mathrm{h} \\ \text { Glass production rate range } & 0.12 \text { to } 0.31 \mathrm{~kg} / \mathrm{h} \\ \text { Nominal feed rate } & 0.43 \mathrm{~L} / \mathrm{h} \\ \text { Maximum feed rate } & 0.55 \mathrm{~L} / \mathrm{h} \\ \text { Process temperature } & 1093 \mathrm{to} 1133^{\circ} \mathrm{C}\end{array}$

(a) This feed composition was developed at Savannah River Laboratory (SRL). 


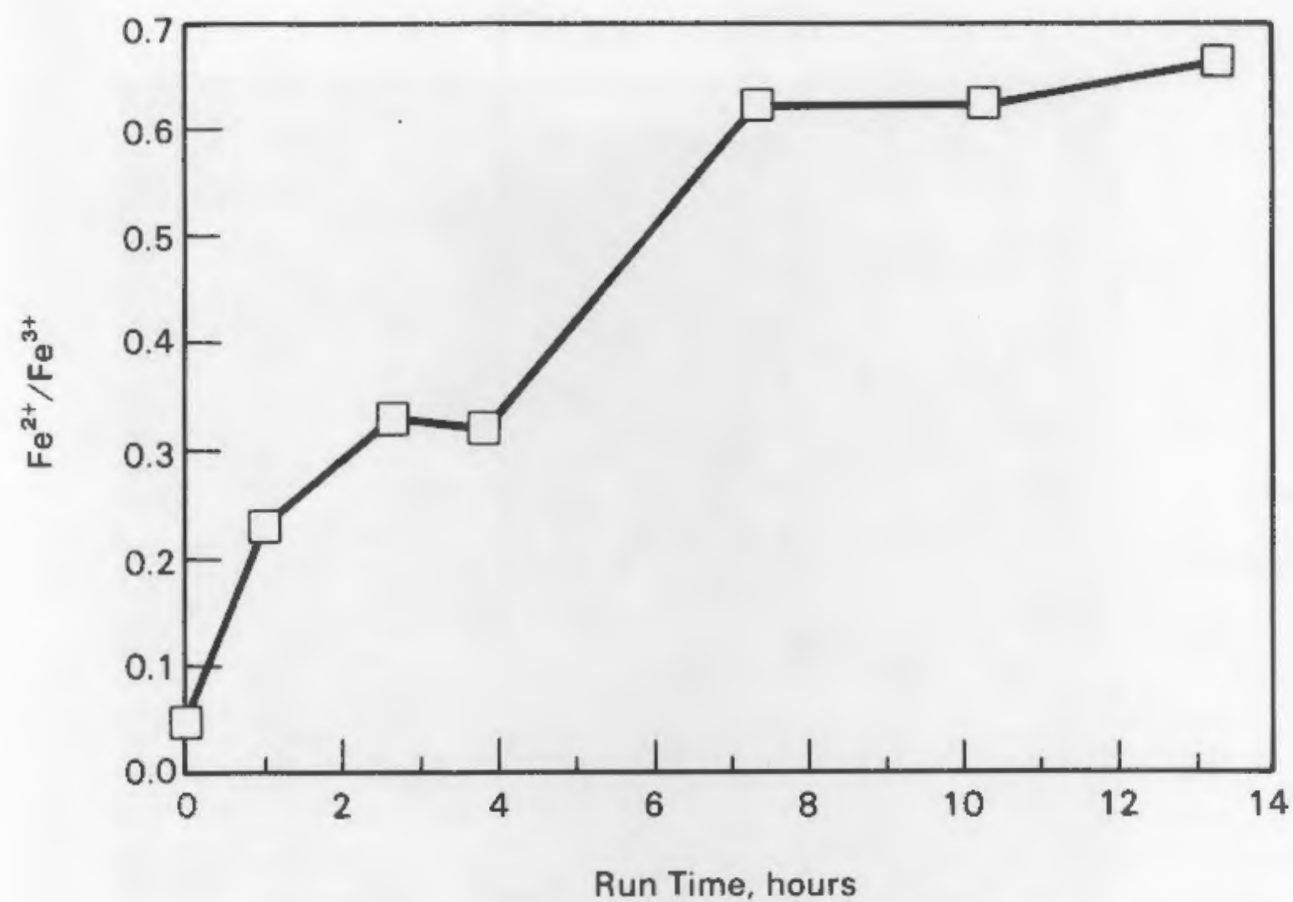

FIGURE 7. Redox Response of LFMM-86-1 Glass

Comparison of the melting behavior of this feed in the LFMM to that in the PSCM and HBCM shows no noticeable difference. The feed melted well in all melters with no problems. A thin section of glass was obtained at $10 \mathrm{~h}$ into the LFMM run and examined with SEM/EDX, revealing the smooth vitreous product with very few cubic spinel-type crystals as shown in Figure 8. The EDX trace is given in Figure 9. This vitreous characteristic was also observed in glass produced during $\mathrm{HBCM}-86-1$.

When the mini-melter crucible was emptied at the end of the run, approximately $1 / 4$ in. of melter "sludge" was noticed in the bottom. This was examined with SEM/EDX and found to contain many crystals with high amounts of $\mathrm{Fe}$ and $\mathrm{Ni}$ and crystals with high amounts of $\mathrm{Fe}$ and $\mathrm{Cr}$. An SEM micrograph of the sludge appears as Figure 10; the EDX traces are given in Figure 11. These crystals are the product of dissolution of a stainless steel thermowell that was inserted into the melt. This thermowell was replaced with one made of Inconel, which is more resistant to glass attack and high temperatures. In subsequent test runs, sludge formation was not observed. 
Feature 1

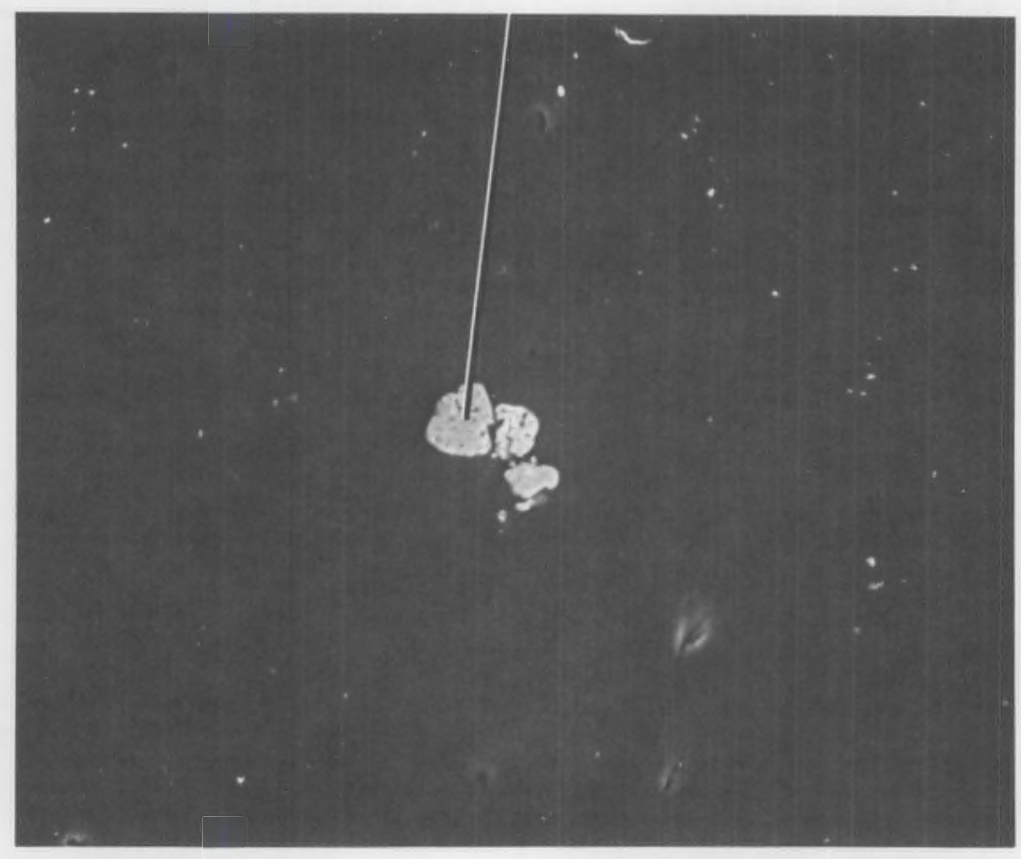

300x Magnification

FIGURE 8. SEM Micrograph of LFMM-86-1 Glass Sample No. 5

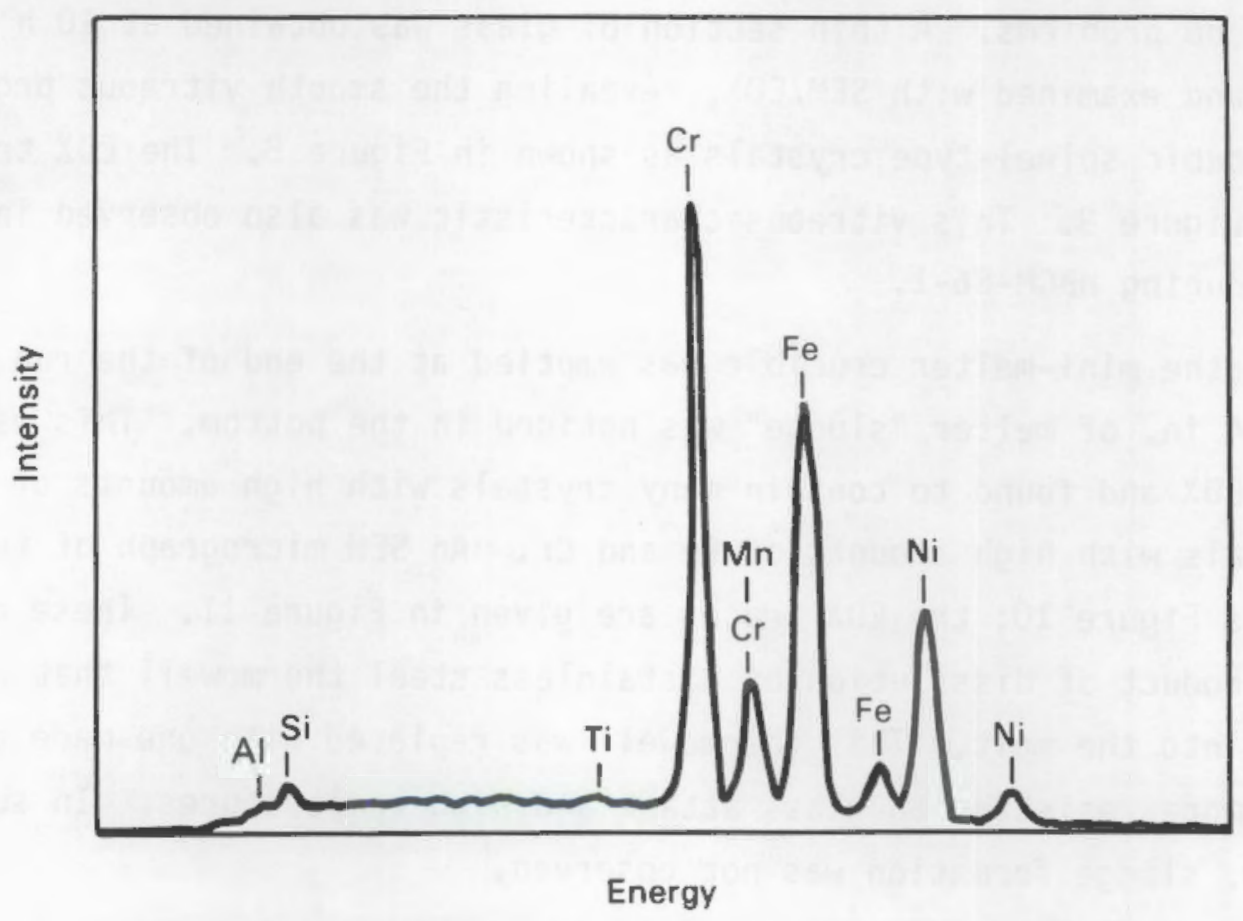

FIGURE 9. EDX Spectra of Feature 1 in Figure 8 


\section{$\begin{array}{lll}\text { Feature } 1 & \text { Feature } 2 & \text { Feature } 3\end{array}$}

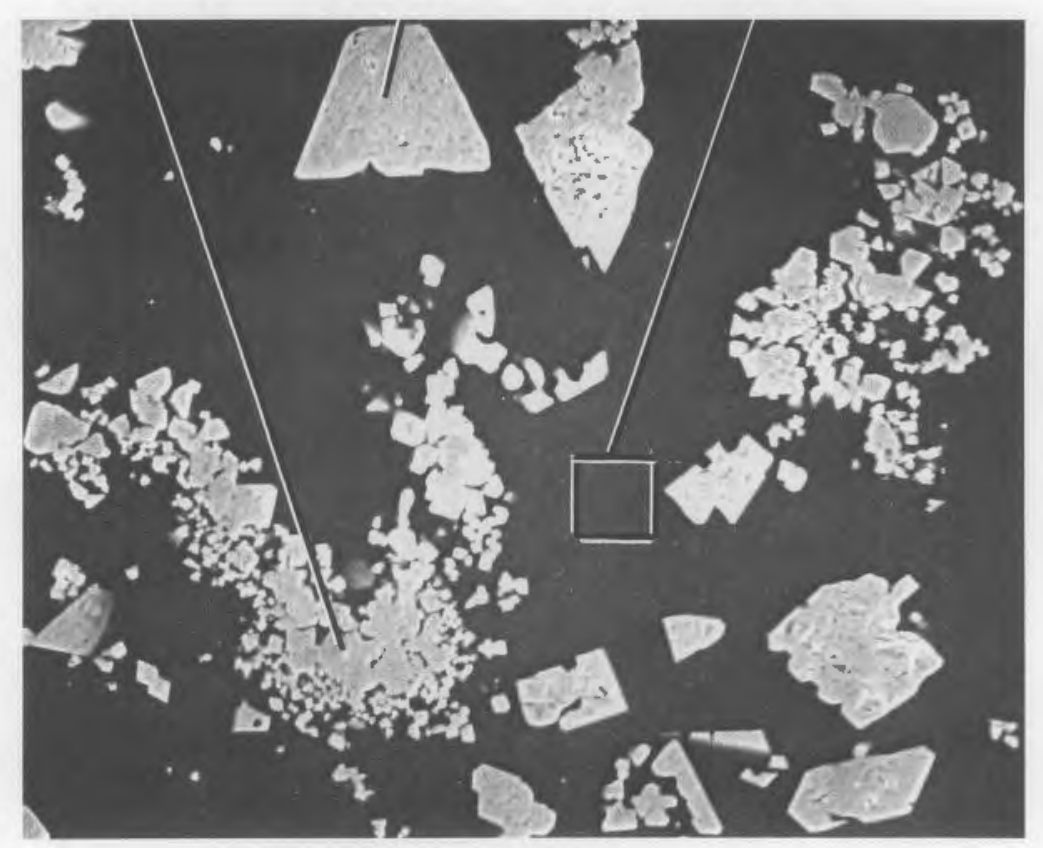

300x Magnification

FIGURE 10. SEM Micrograph of LFMM-86-1 Sludge

RUN LFMM-86-2

Experimental run LFMM-86-2 lasted $14 \mathrm{~h} 40 \mathrm{~min}$. Melter turnover occurred in approximately $5.2 \mathrm{~h}$. A total of $4.94 \mathrm{~L}$ of aged (approximately 1-year-old) PSCM-22 feed was processed, producing $1.69 \mathrm{~kg}$ of glass. This feed had been run unaged in the PSCM during PSCM-22 (July 17 through August 2, 1985), and in the ECM during ECM-86-1 (May 22 through 23, 1986). The same target composition had been run in the HBCM during HBCM-85-1 (April 17 through May 2, 1985). Crushed PSCM-22 glass was used to dry-feed the melter prior to slurry feeding. The conditions and results for run LFMM-86-2 are summarized in Table 4.

This feed did not process well in the LFMM. The cold cap did not spread out well. A "tower" was built up on the glass surface under the feed inlet, growing with time and occasionally toppling. This peak grew up to $7.6 \mathrm{~cm}$ in height. The cold cap was rigid and non-porous. Venting occurred around the edges of the cold cap. This may have been caused by proximity of the hot walls of the crucible. However, this behavior had also been observed during ECM-86-1. During that run, towers were built up, sometimes growing tall enough 


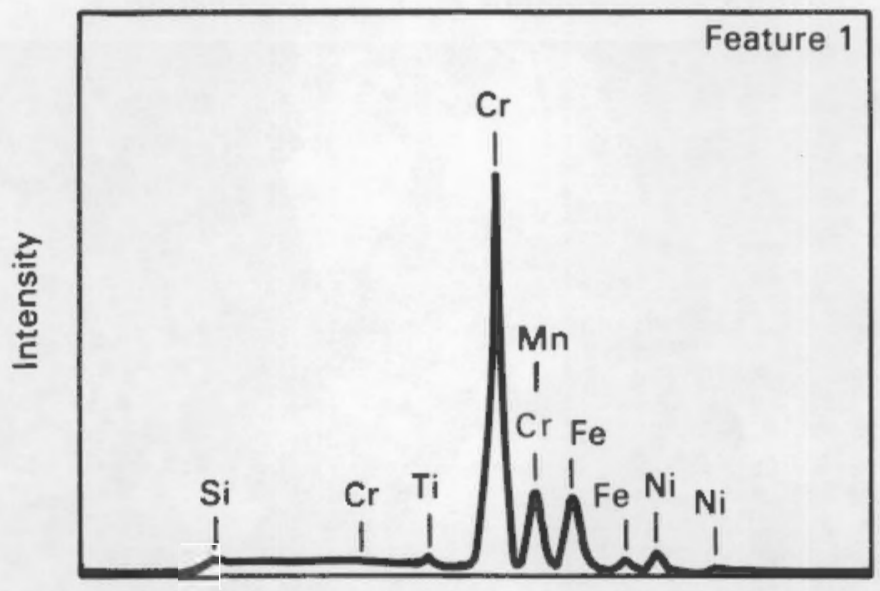

Energy
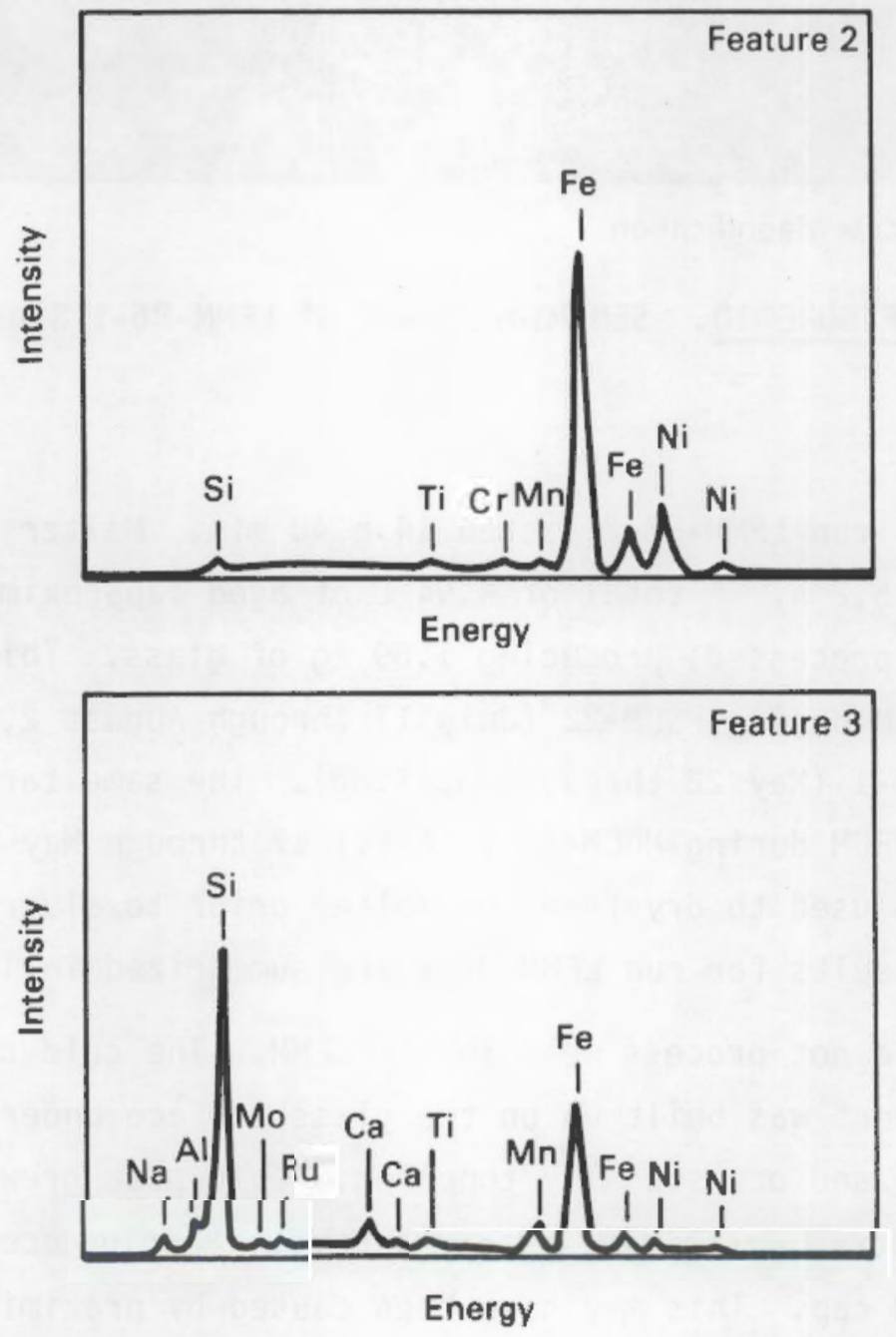

FIGURE 11. EDX Spectra of Features in Figure 10 


\section{TABLE 4. LFMM-86-2 Run Conditions and Results}

Feed used

Total run time

Amount of feed processed

Amount of glass produced

Feed rate range

Glass production rate range

Nominal feed rate

Maximum feed rate

Process temperature
PSCM-22 feed with sugar, as used in ECM-86-1

$14 \mathrm{~h} 40 \mathrm{~min}$

$4.94 \mathrm{~L}$

$1.69 \mathrm{~kg}$

0.29 to $0.52 \mathrm{~L} / \mathrm{h}$

0.10 to $0.21 \mathrm{~kg} / \mathrm{h}$

$0.29 \mathrm{~L} / \mathrm{h}$

$0.34 \mathrm{~L} / \mathrm{h}$

1107 to $1132^{\circ} \mathrm{C}$

to reach the feed nozzle and clog it. The feed processed so poorly during ECM-86-1 that a "fresh" batch of feed (used in HBCM-86-2) was obtained to replace it for the remainder of the run.

The glass output became "stringy" after $6 \mathrm{~h}$ into the run. This was caused by the changing composition of the glass output. The feed contained a higher amount of $\mathrm{SiO}_{2}$ than did the glass that was dry-fed at the beginning of the run. This effectively raised the viscosity of the glass, causing it to string. In addition to being higher in $\mathrm{SiO}_{2}$, the feed was lower in $\mathrm{B}_{2} \mathrm{O}_{3}$ and $\mathrm{Fe}_{2} \mathrm{O}_{3}$ than was the starting glass composition. The composition of the glass gradually approached that of the feed composition. This is illustrated in Figure 12, where $\mathrm{SiO}_{2}, \mathrm{Fe}_{2} \mathrm{O}_{3}$, and $\mathrm{B}_{2} \mathrm{O}_{3}$ compositions are plotted against run time. The shape of the $\mathrm{SiO}_{2}$ curve suggests that the contents of the melt crucible are well mixed.

The redox of the glass increased, then leveled to a $\mathrm{Fe}^{2+} / \mathrm{Fe}^{3+}$ of 0.13 to 0.18 at approximately $7 \mathrm{~h}$ into the run, as illustrated in Figure 13 . This ferrous-ferric ratio was observed also during PSCM-22, but not observed during HBCM-85-1. The ferrous-ferric ratio was lower during the latter run when identical target feed was run. It is not known why this occurred.

Analyses of the feed samples taken during the run show little deviation from the bulk composition of the feed analyzed prior to the run. This indicates that minimal settling of the slurry components occurred in the feed lines. 

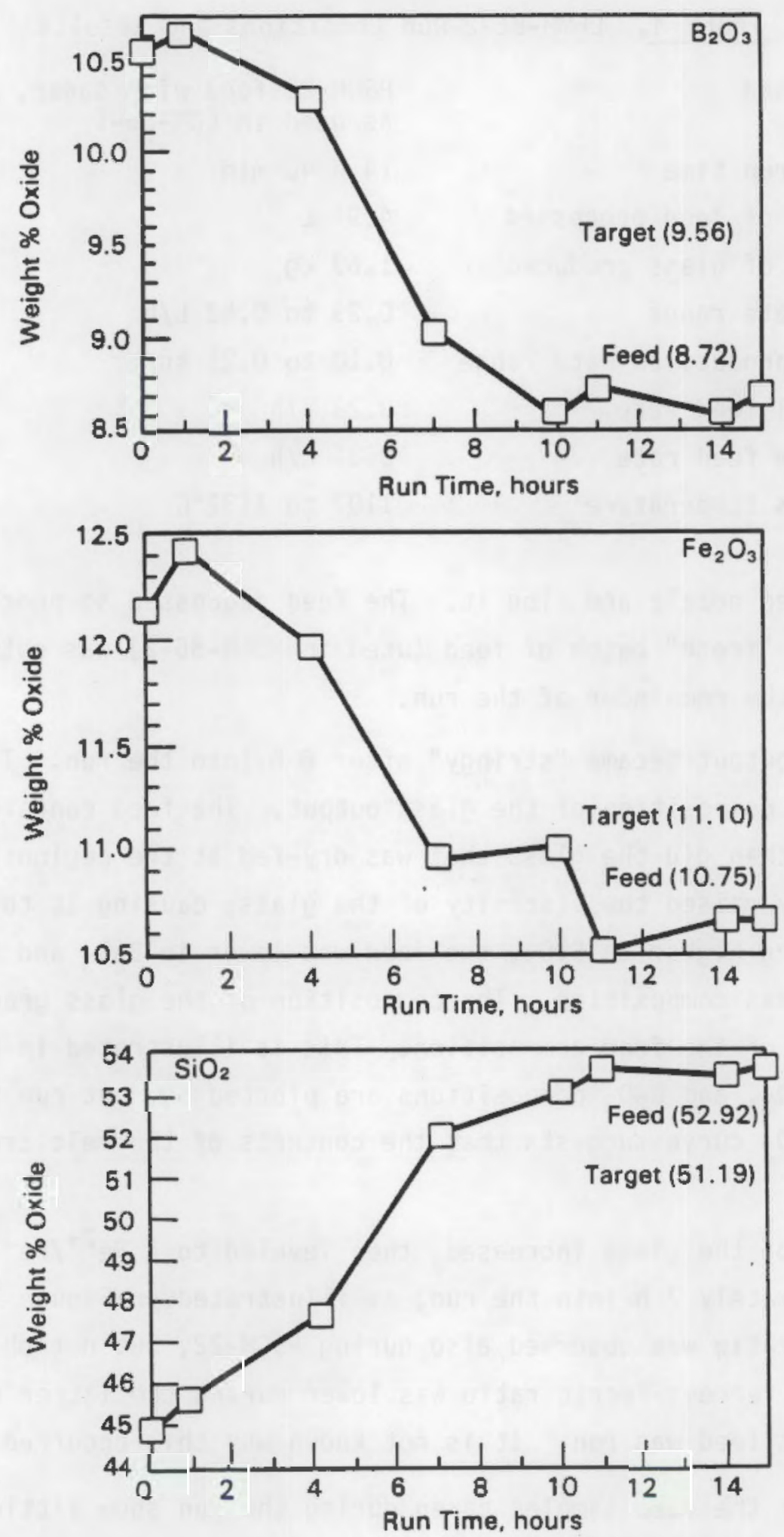

FIGURE 12. Change in Oxide Composition of LFMM-86-2 Output Glass 


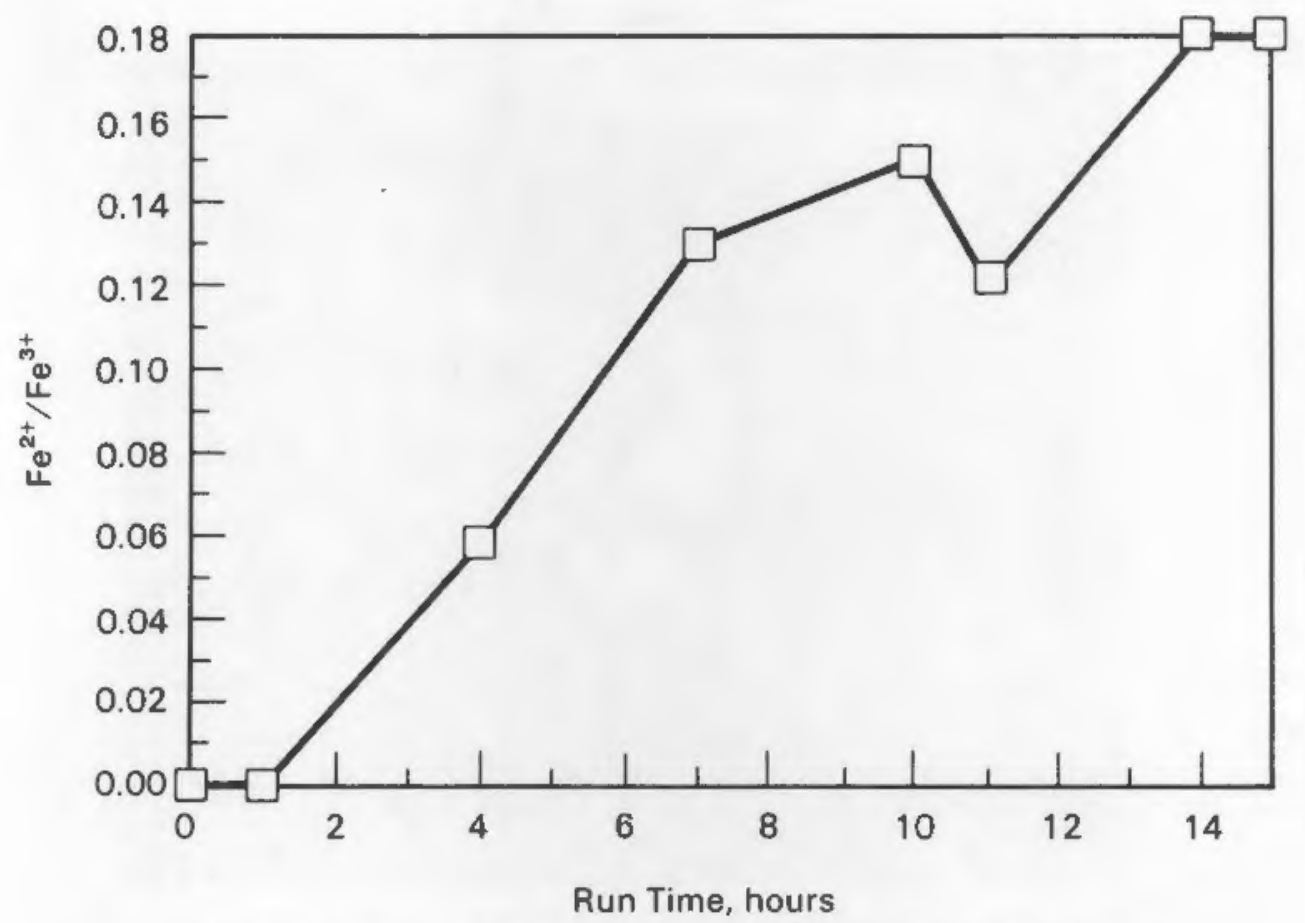

FIGURE 13. Redox Response of LFMM-86-2 Glass

A thin section of a glass sample taken $11 \mathrm{~h}$ into the run was examined with optical microscopy and SEM/EDX. Many cubic spinel-type crystals $\left[(\mathrm{Fe}, \mathrm{Cr})\left(\mathrm{Fe}, \mathrm{Ni}_{2} \mathrm{O}_{4}\right]\right.$ high in $\mathrm{Cr}$ and $\mathrm{Fe}$ with a small amount of $\mathrm{Ni}$ were revealed. These crystals were scattered throughout the glass and measured approximately 1 to $2.7 \mu \mathrm{m}$ across. Figure 14 shows an SEM micrograph of the glass. Figure 15 shows EDX traces of the crystals observed. These crystals were al so observed in glasses produced in PSCM-22 and HBCM-85-1.

\section{RUN LFMM-86-3}

Experimental run LFMM-86-3 lasted 11 h 50 min. Melter turnover occurred in approximately $8 \mathrm{~h}$, based on mass of glass output. A total of $5.19 \mathrm{~L}$ of HBCM-86-2 feed (400 $\mathrm{g} / \mathrm{L}$ oxide loading) was processed, producing $1.14 \mathrm{~kg}$ of glass. This feed was run in the ECM during ECM-86-1 (second feed), the HBCM during HBCM-86-2 (April 26 to May 2, 1986), and its equivalent in the PSCM during a portion of PSCM-22. Crushed glass from PSCM-22 was used to dry-feed the melter prior to slurry feeding. The conditions and results for run LFMM-86-3 are listed in Table 5. 
Feature 1

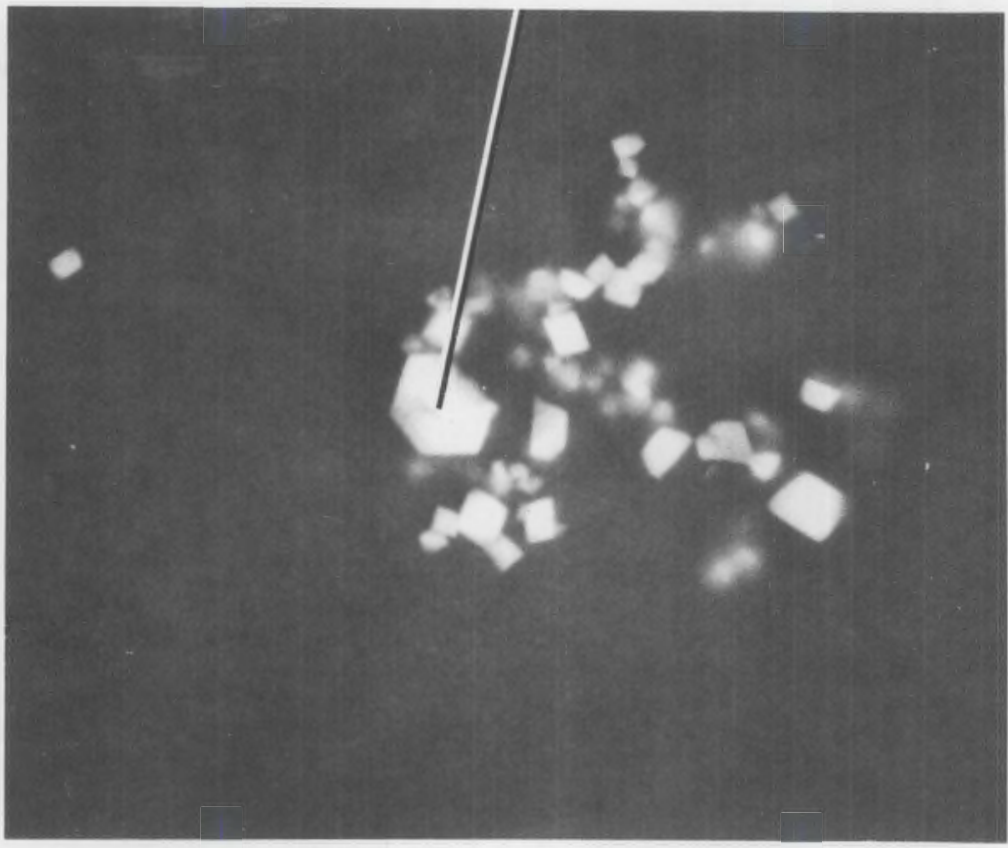

$3000 \times$ Magnification

FIGURE 14. SEM Micrograph of LFMM-86-2 Glass Sample No. 5

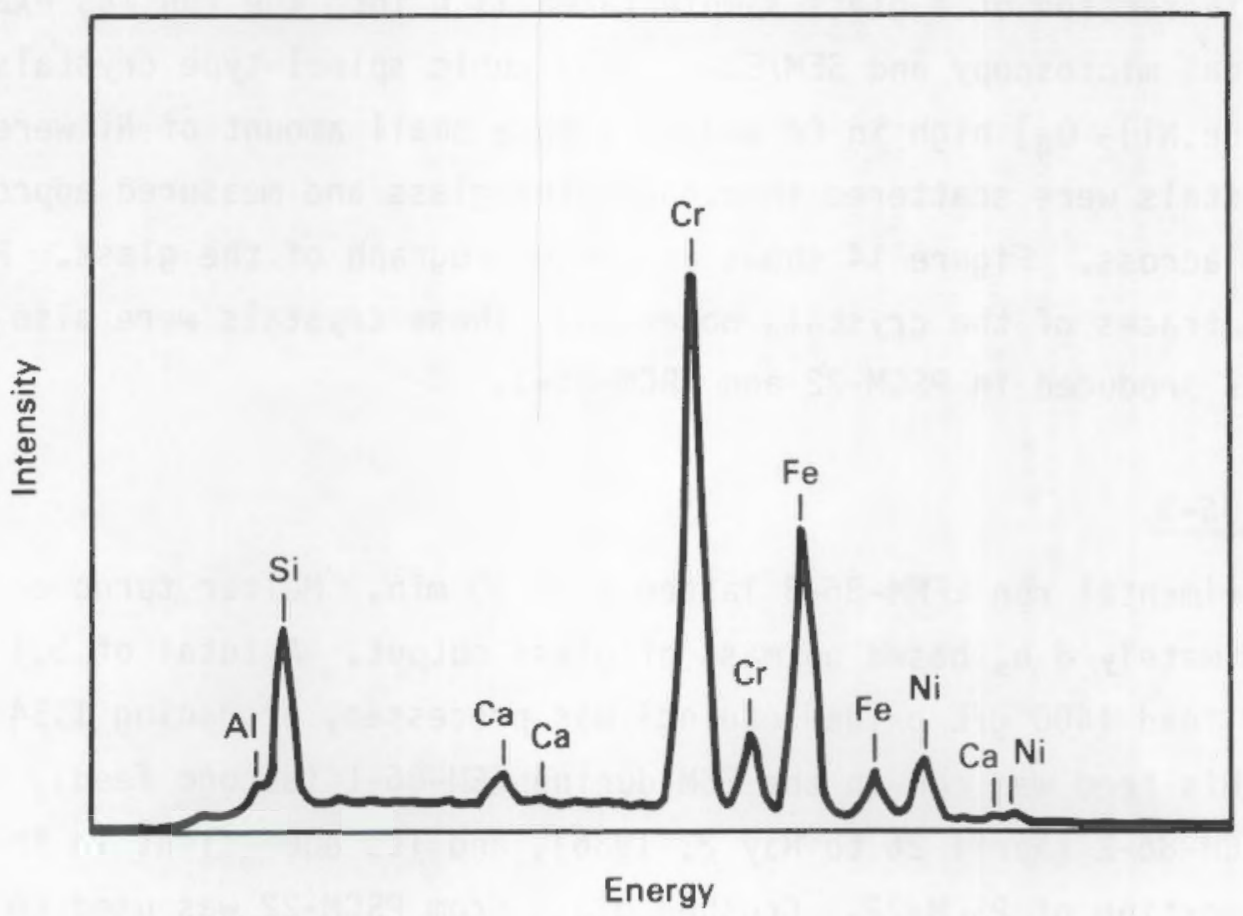

FIGURE 15. EDX Spectra of Feature 1 in Figure 14 


\section{TABLE 5. LFMM-86-3 Run Conditions and Results}

$\begin{array}{ll}\text { Feed used } & \begin{array}{l}\text { HBCM }-86-2 \text { feed, as used in ECM-86-1 } \\ (400 \mathrm{~g} / \mathrm{L} \text { oxides })\end{array} \\ \text { Total run time } & 11 \mathrm{~h} 50 \mathrm{~min} \\ \text { Amount of feed processed } & 5.19 \mathrm{~L} \\ \text { Amount of glass produced } & 1.14 \mathrm{~kg} \\ \text { Feed rate range } & 0.35 \mathrm{to} 0.51 \mathrm{~L} / \mathrm{h} \\ \text { Glass production rate range } & 0.06 \text { to } 0.14 \mathrm{~kg} / \mathrm{h} \\ \text { Nominal feed rate } & 0.35 \mathrm{~L} / \mathrm{h} \\ \text { Maximum feed rate } & 0.49 \mathrm{~L} / \mathrm{h} \\ \text { Process temperature } & 1096 \text { to } 1130^{\circ} \mathrm{C}\end{array}$

This feed processed better than that used in LFMM-86-2, but more poorly than that used in LFMM-86-1. The cold cap spread out slowly, forming a small mound approximately 1 in. high. The feed tended to form a small tower, which toppled readily. Good venting was present, both around and through the cold cap.

Although this feed had better processing characteristics than the feed used in LFMM-86-2, the glass production rate was lower. This was caused by the fact that the feed was dilute and contained roughly $300 \mathrm{~g} / \mathrm{L}$ oxides versus the target of $400 \mathrm{~g} / \mathrm{L}$ oxides. Analysis of the feed samples taken during the run indicated that negligible settling of components occurred in the feed lines.

After $6 \mathrm{~h}$, the glass output began to form clumps of droplets resembling grape clusters. Many strings were formed as the drops fell from the crucible outlet tube. This was caused by the changing composition of the glass output. As in LFMM-86-2, the feed contained more $\mathrm{SiO}_{2}$ than did the starting dry-fed glass. The feed was also lower in $\mathrm{B}_{2} \mathrm{O}_{3}$ than the starting glass. The glass composition eventually approached that of the feed composition. This is illustrated in Figure 16, where $\mathrm{SiO}_{2}$ and $\mathrm{B}_{2} \mathrm{O}_{3}$ weight percent are plotted against run time. 


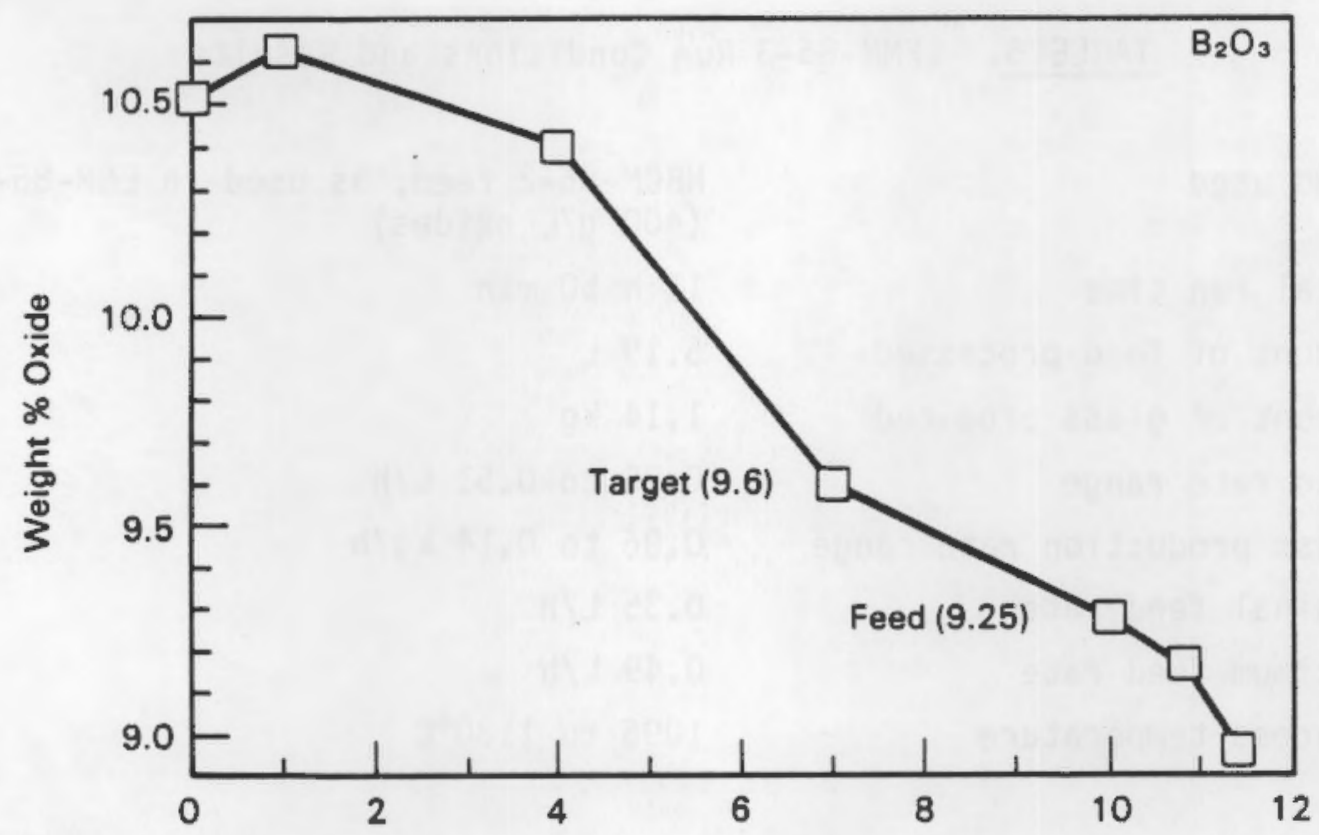

Run Time, hours

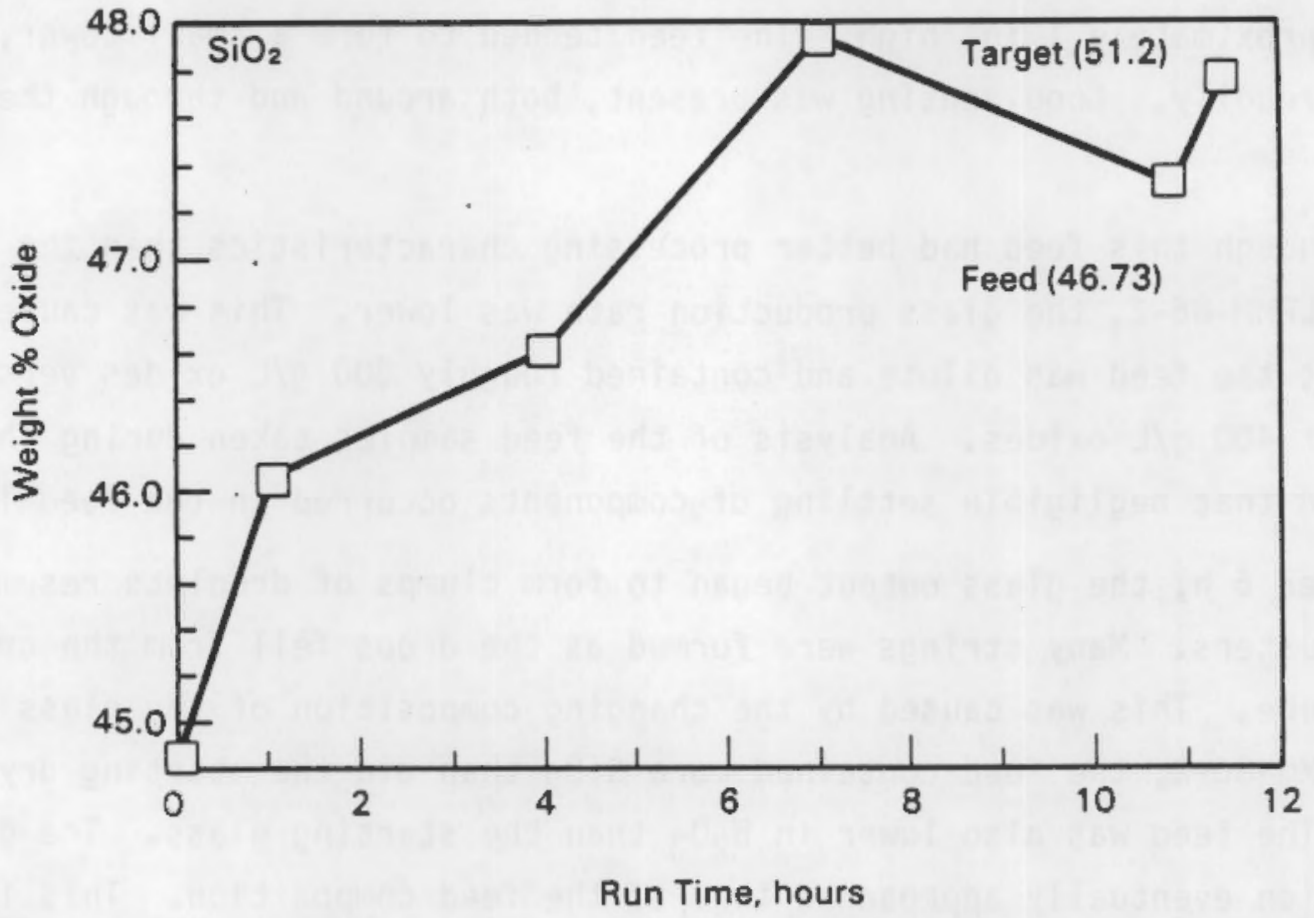

FIGURE 16. Change in Oxide Composition of LFMM-86-3 Output Glass 
The glass output remained essentially oxidized over the entire run. This behavior was expected, as this feed contained no sugar. Feeds that contained no sugar, and which were processed in PSCM-22, HBCM-85-1, and HBCM-86-2, exhibited similar behavior.

Examination of a thin section of output glass (sampled $10.83 \mathrm{~h}$ into the run) with optical microscopy and SEM/EDX revealed the presence of many cubic spinel-type crystals $\left[(\mathrm{Fe}, \mathrm{Cr})\left(\mathrm{Fe}, \mathrm{Ni}_{2}\right)_{2}{ }_{4}\right]$ containing high amounts of $\mathrm{Cr}$ and $\mathrm{Fe}$ with a small amount of $\mathrm{Ni}$. Figure 17 shows an SEM micrograph of the glass. Figure 18 shows an EDX trace of the crystals observed. These crystals measured approximately 1.7 to 3.7 microns across. These crystals were also observed in glasses produced in PSCM-22, HBCM-85-1, and LFMM-86-2.

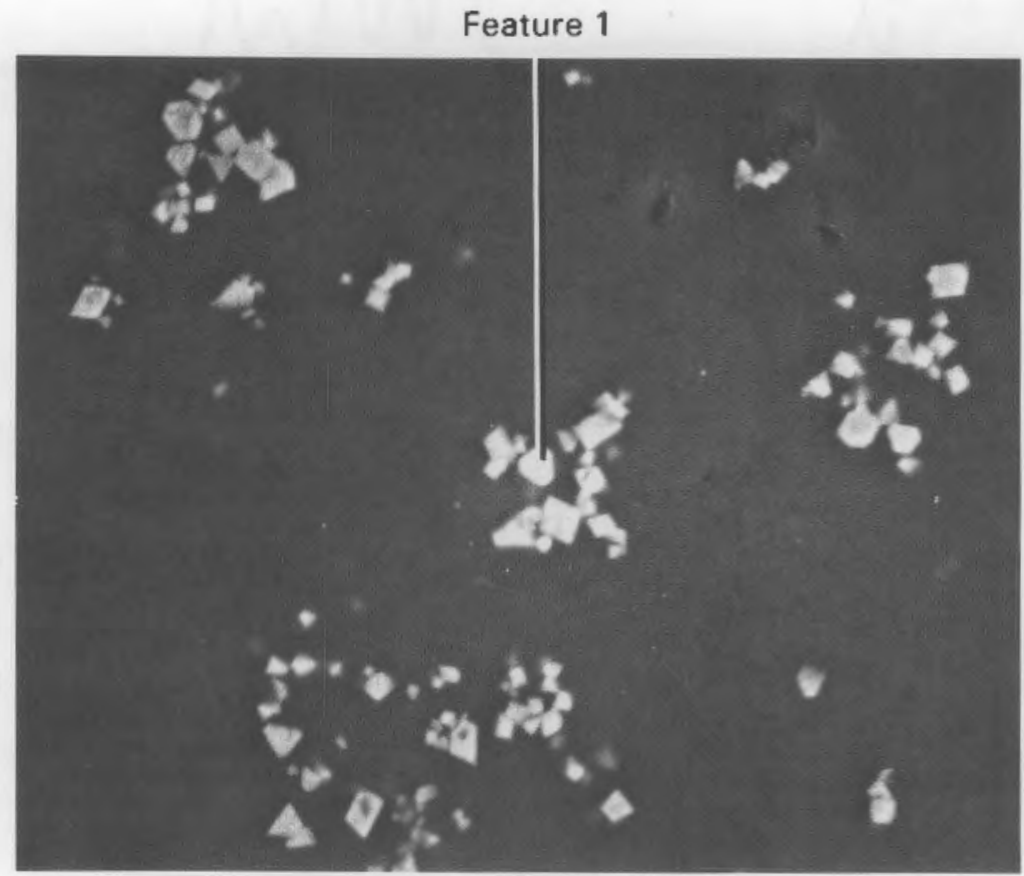

1000x Magnification

FIGURE 17. SEM Micrograph of LFMM-86-3 Glass Sample No. 5 


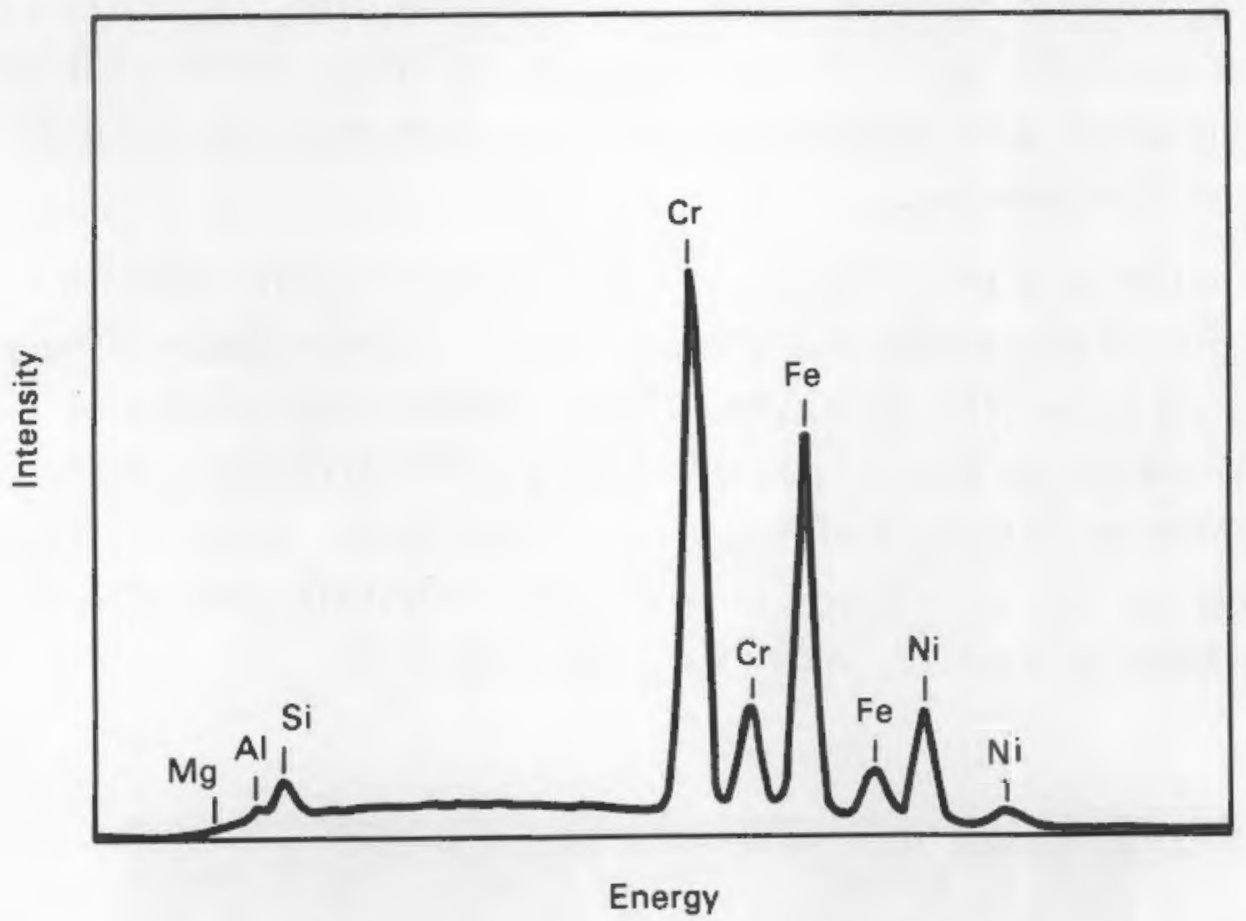

FIGURE 18. EDX Spectra of Feature 1 in Figure 17

RUN LFMM-86-4

Experimental run LFMM-86-4 lasted 11 h 26 min. Melter turnover occurred in approximately $6 \mathrm{~h}$. A total of $5.17 \mathrm{~L}$ of freshly batched FRG 8 composition(a) feed was processed, producing $1.68 \mathrm{~kg}$ of glass. This feed composition was run in the PSCM during PSCM-20 (March 27 through April 11, 1985) and ECM85-4 and 5 (February 1985). Laboratory-batched glass with the FRG composition was placed in the melter prior to feeding. Conditions and results for run LFMM-86-4 are summarized in Table 6.

The laboratory-batched feed did not contain the sugar that was present in feeds processed in the ECM and PSCM. Zeolite was not added to this feed as it was to the ECM and PSCM feeds. This should not have significantly affected the melt behavior, as sugar reduction and substituting dry chemicals for zeolite substituents were shown to not affect the melt behavior and subsequent processability of the FRG feed during the ECM and PSCM runs.

(a) Developed for the Federal Republic of Germany (FRG). 


\section{TABLE 6. LFMM-86-4 Run Conditions and Results}

Feed used

Total run time

Amount of feed processed

Amount of glass produced

Feed rate range

Glass production rate range

Nominal feed rate

Maximum feed rate

Process temperature
Laboratory-batched FRG 8 feed

11 h 26 min

$5.17 \mathrm{~L}$

$1.68 \mathrm{~kg}$

0.41 to $0.55 \mathrm{~L} / \mathrm{h}$

0.05 to $0.23 \mathrm{~kg} / \mathrm{h}$

$0.46 \mathrm{~L} / \mathrm{h}$

Not determined

1079 to $1132^{\circ} \mathrm{C}$

The FRG 8 feed processed fairly well in the LFMM. The cold cap tended to spread out, and then form a small tower. Even so, the feed processed quickly. When feeding was stopped, the cold cap burned off in approximately 4 min. The cold cap formed in the ECM and PSCM runs was thin and rigid. No tower formation was seen. The feed did process very quickly in the ECM $(3.5 \mathrm{~L} / \mathrm{h})$ compared with average ECM feed rates $(2.5 \mathrm{~L} / \mathrm{h})$. The feed processed more slowly in the PSCM than predicted, based on the ECM run results.

The ICP analyses of the feed samples taken during the run show that negligible settling of the feed occurred in the feed lines. The analyses of the glass present in the crucible prior to feeding and the final output glass show that the glass composition eventually reached that of the bulk feed composition. The glass output remained essentially oxidized over the run. This is expected behavior for feeds containing no sugar or formic acid (sugar and formic acid act as reducing agents).

A thin section of a glass sample taken $10 \mathrm{~h}$ into the run was examined with optical microscopy. The glass was very clear, with only a few small crystals seen, and it compared well with glass produced during PSCM-20. 
RUN LFMM-86-5

Experimental run LFMM-86-5 lasted $19 \mathrm{~h} 32 \mathrm{~min}$. Melter turnover occurred in approximately $8 \mathrm{~h}$, based on mass of glass output. A total of $8.35 \mathrm{~L}$ of WV

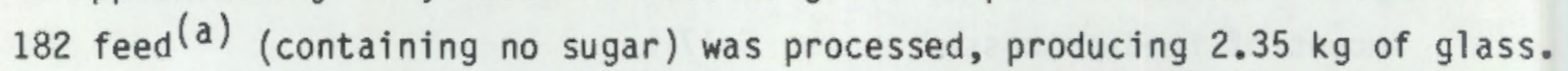
This target feed composition was run in the PSCM during PSCM-19/19E (August 20 through September 1, and September 19 through 21, 1984). Prior to slurry feeding, SRL 165 black frit was used to dry-feed the melter. The feed analysis showed the $\mathrm{MnO}_{2}$ level to be high relative to the target, and this could affect the melting behavior. Because this was a minor constituent (less than 3 wt\%), no effect was anticipated for the LFMM-85-5 run. In Table 7, the conditions and results of this run are summarized.

The WV 182 feed processed fairly well in the LFMM. The cold cap spread out well, forming a small dome with a pool of liquid slurry in the center. A rather porous cold cap was formed, with a somewhat viscous material surrounding it. This type of cold cap was formed in PSCM-19E. When the crucible was overfed, the cold cap kept the same appearance and the entire surface rose very slowly toward the top of the crucible. Hence, nominal and maximum feed rates were difficult to determine.

The ICP analyses of the feed samples taken during the run show that negligible settling of feed occurred in the lines. Analyses of the glass output

TABLE 7. LFMM-86-5 Run Conditions and Results

$\begin{array}{ll}\text { Feed used } & \text { WV } 182, \text { no sugar } \\ \text { Total run time } & 19 \mathrm{~h} 32 \mathrm{~min} \\ \text { Amount of feed processed } & 8.35 \mathrm{~L} \\ \text { Amount of glass produced } & 2.35 \mathrm{~kg} \\ \text { Feed rate range } & 0.36 \text { to } 0.48 \mathrm{~L} / \mathrm{h} \\ \text { Glass production rate range } & 0.06 \text { to } 0.17 \mathrm{~kg} / \mathrm{h} \\ \text { Nominal feed rate } & 0.41 \mathrm{~L} / \mathrm{h} \\ \text { Maximum feed rate } & 0.43 \mathrm{~L} / \mathrm{h} \\ \text { Process temperature } & 1132 \mathrm{to} 1150^{\circ} \mathrm{C}\end{array}$

(a) Composition developed at PNL for West Valley (WV) Nuclear Services. 
showed that it remained essentially oxidized during the run, as the feed did not contain sugar or formic acid. The glass composition changed with time during the run due to compositional differences between the glass present prior to feeding and the feed itself. This is illustrated in Figure 19, in which $\mathrm{B}_{2} \mathrm{O}_{3}$ and $\mathrm{SiO}_{2}$ weight percents are plotted against the run time. The shapes of these curves suggest the occurrence of true ideal mixing of crucible contents. Figure 20 gives the actual time distribution curve of $\mathrm{B}_{2} \mathrm{O}_{3}$ as compared to distribution curves representing "ideal mixing" with mean particle residence times of 3 and $4 \mathrm{~h}$. This comparison shows that the crucible contents are mixed well and that its mean particle residence time is between 3 and $4 \mathrm{~h}$. Despite this residence time, it takes approximately twice that long to achieve complete turnover of crucible contents.

A sample of the cold cap was sectioned, polished, and examined with SEM/EDX. The interface area between the glassy matrix and the cold cap consisted of mainly a calcium phosphate phase containing a small amount of rare earth (cerium). This is shown in Figure 21. Figure 22 gives EDX traces of the phases seen. This phase was also observed in the PSCM-19 surface material (Goldman 1985; Goldman, Chick, and Blair 1985). In the cold cap, phases containing relatively high amounts of $\mathrm{Si}$ are seen. A micrograph of this area is given in Figure 23. Figure 24 is an EDX trace of the phase mentioned.

Examination of a thin section of output glass (sampled $12.5 \mathrm{~h}$ into the run) with optical microscopy and SEM/EDX revealed the presence of a few small crystals containing Ru. Very few of these crystals were observed. Figure 25 shows an SEM micrograph of the glass. Figure 26 shows an EDX trace of the crystals observed. A small amount of crystals was observed in output glass produced by PSCM-19/19E.

\section{RUN LFMM-86-6}

Experimental run LFMM-86-6 lasted 17 h $55 \mathrm{~min}$. Melter turnover occurred in approximately $6.5 \mathrm{~h}$, based on mass of glass output. A total of $8.28 \mathrm{~L}$ of WV 182 feed (containing $75 \mathrm{~g} / \mathrm{L}$ sugar) was processed, producing $2.23 \mathrm{~kg}$ of glass. 

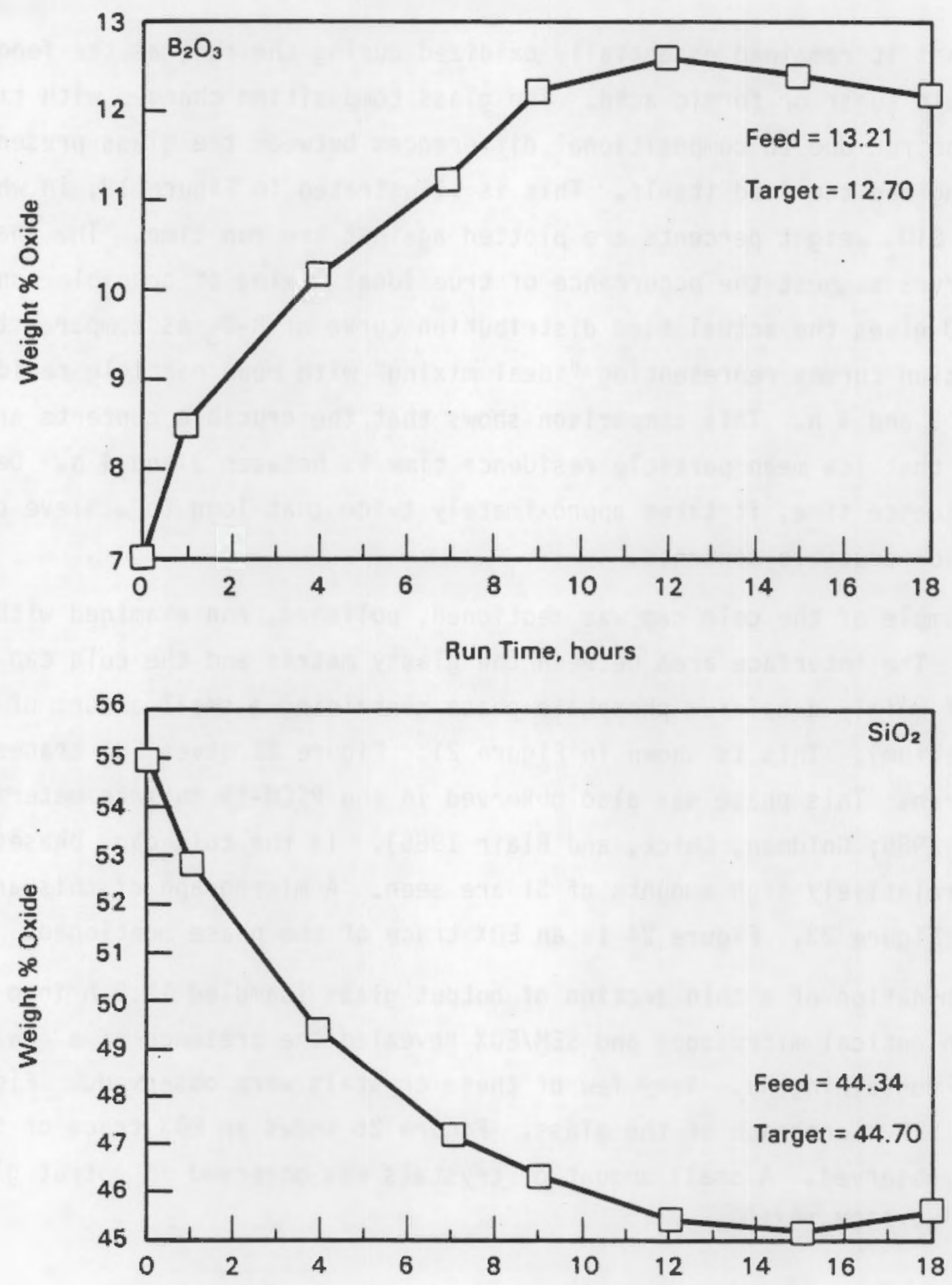

Run Time, hours

FIGURE 19. Change in Oxide Composition of LFMM-86-5 Output Glass 


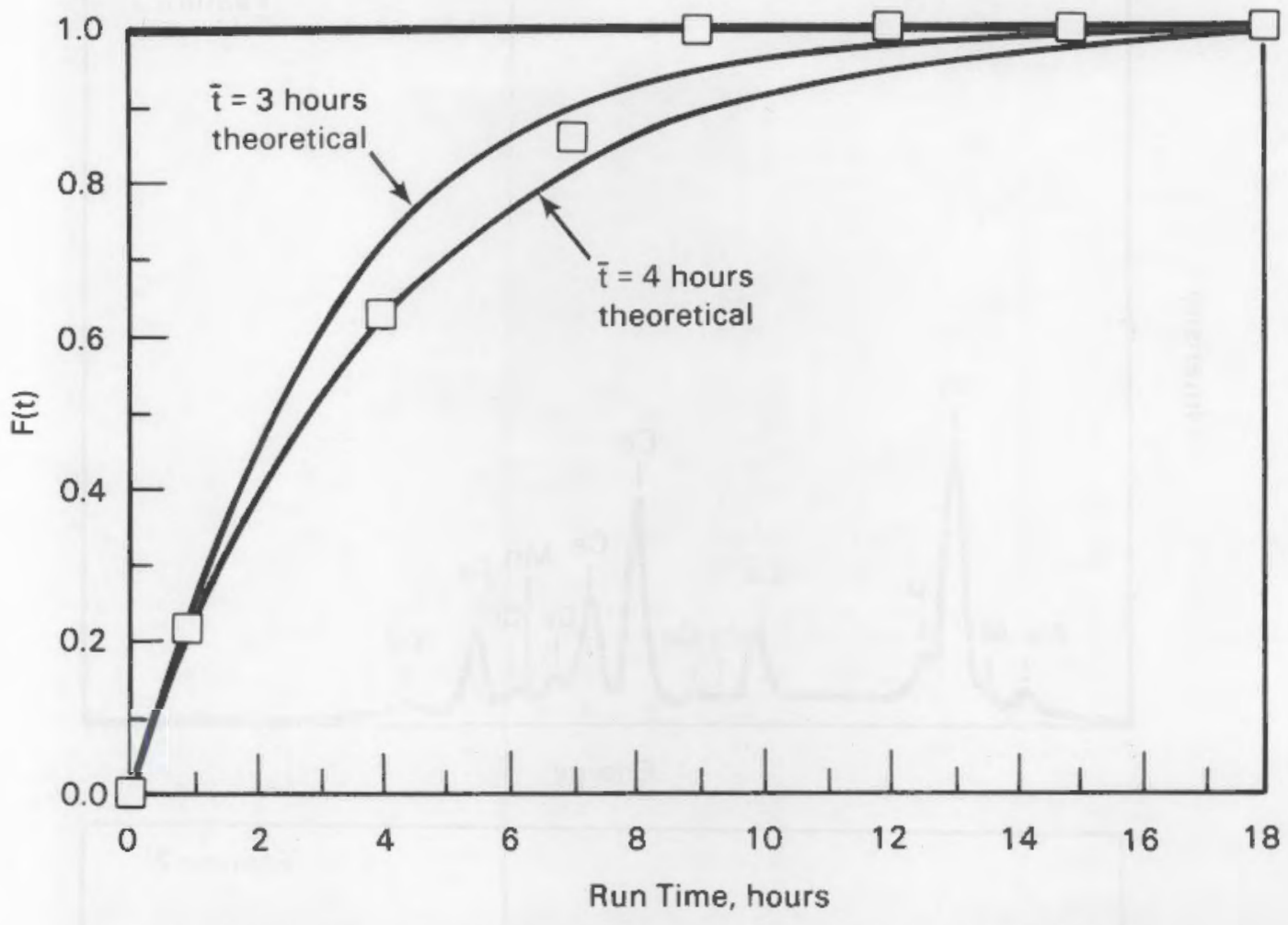

FIGURE 20. Time Distribution of $\mathrm{B}_{2} \mathrm{O}_{3}$ in LFMM-86-5: Comparison with Theoretical Distribution

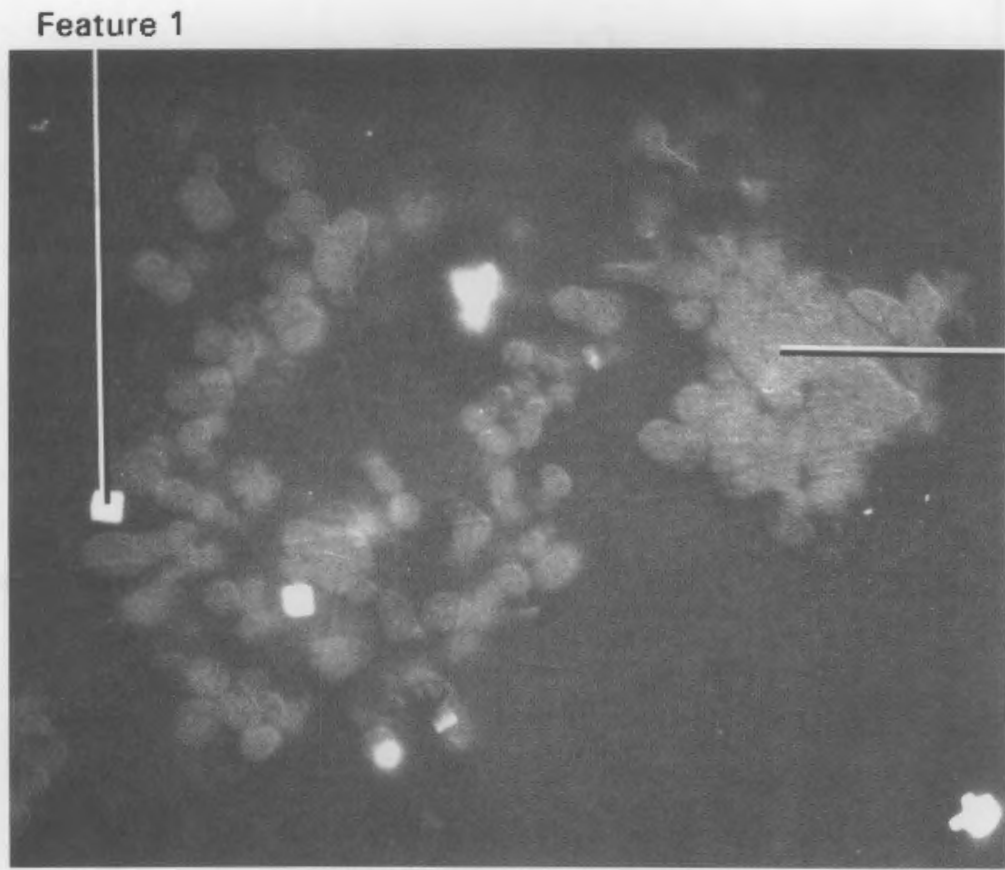

Feature 2

3000x Magnification

FIGURE 21. SEM Micrograph of LFMM-86-5 Cold Cap Interface 

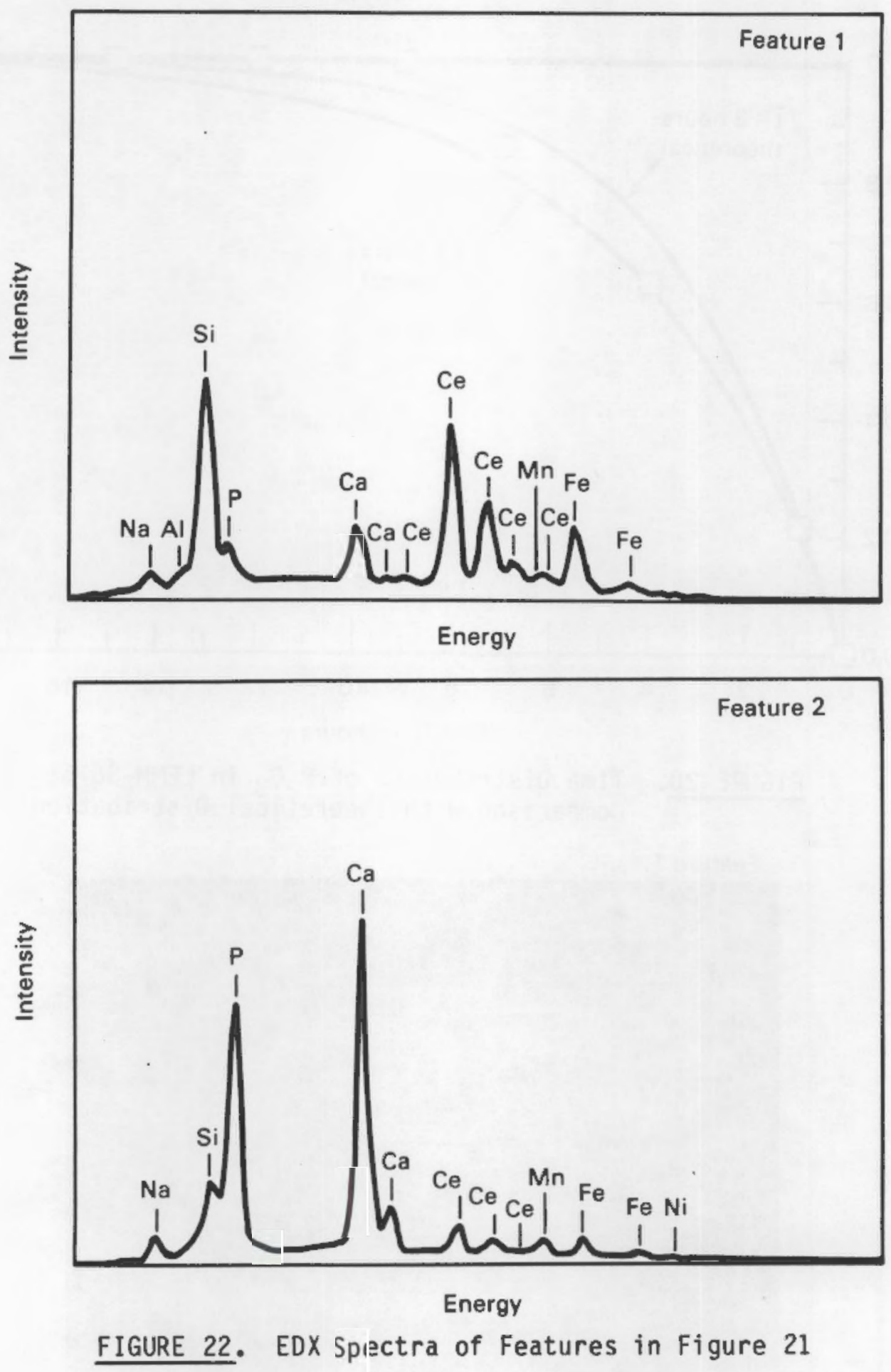
Feature 1

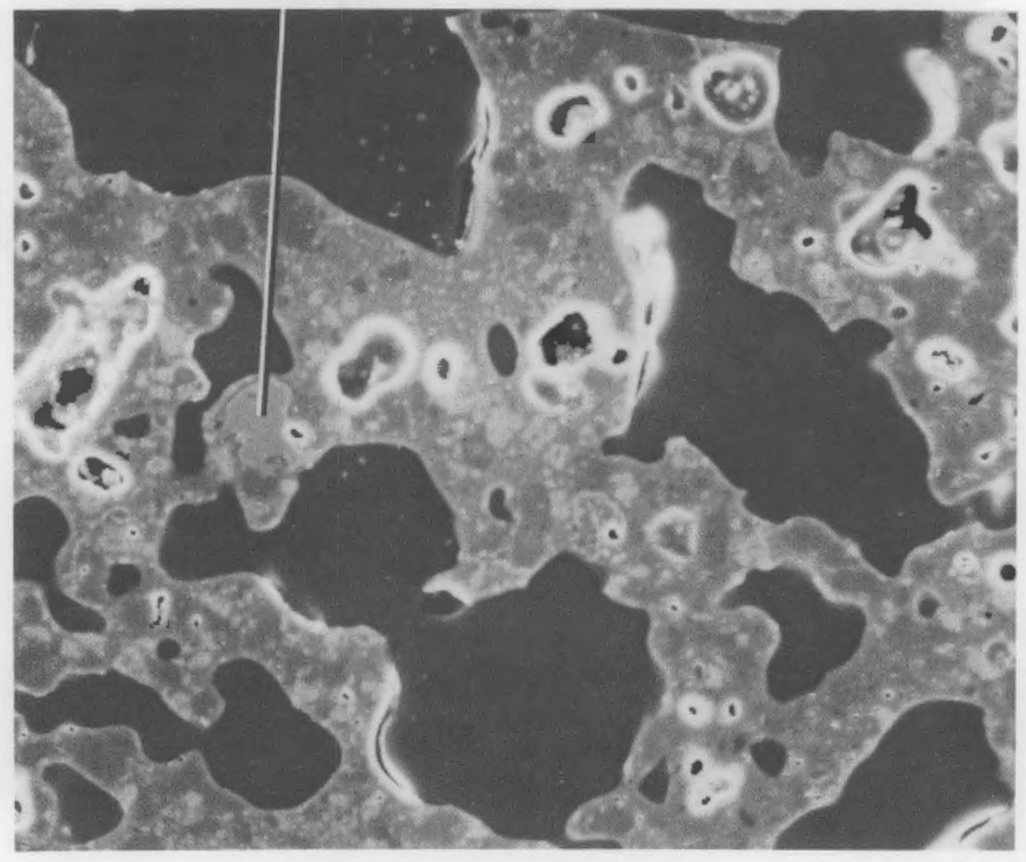

300x Magnification

FIGURE 23. SEM Micrograph of LFMM-86-5 Cold Cap

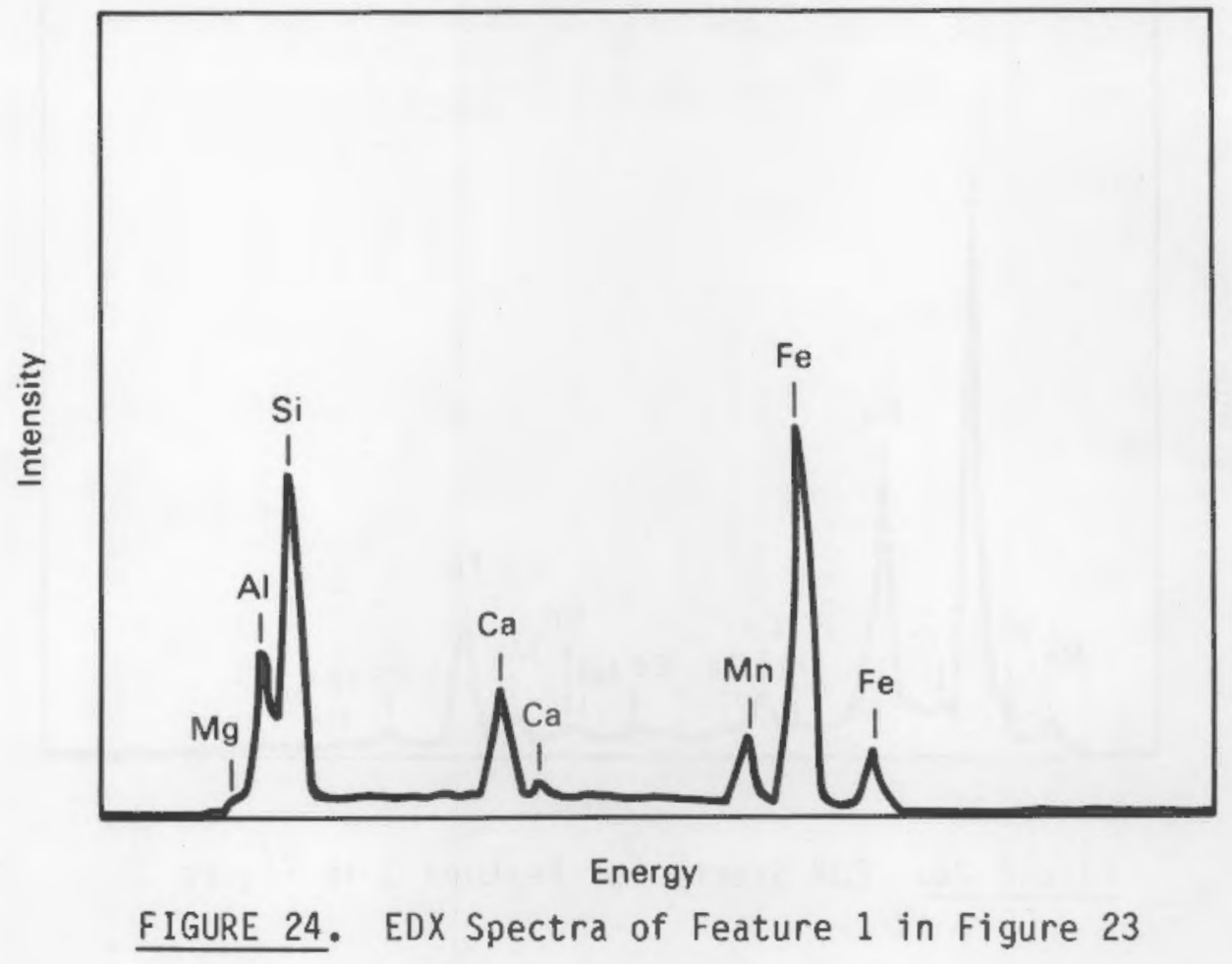


Feature 1

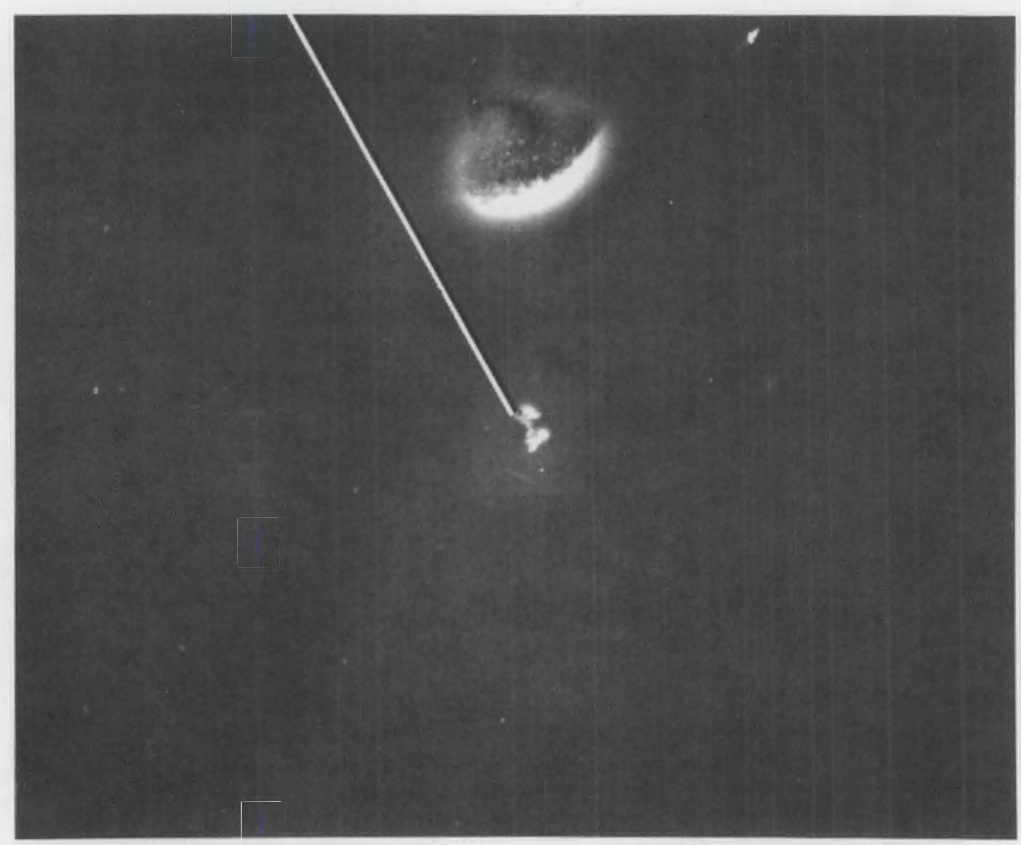

1000x Magnification

FIGURE 25. SEM Micrograph of LFMM-86-5 Output Glass (12.5 h into Run)

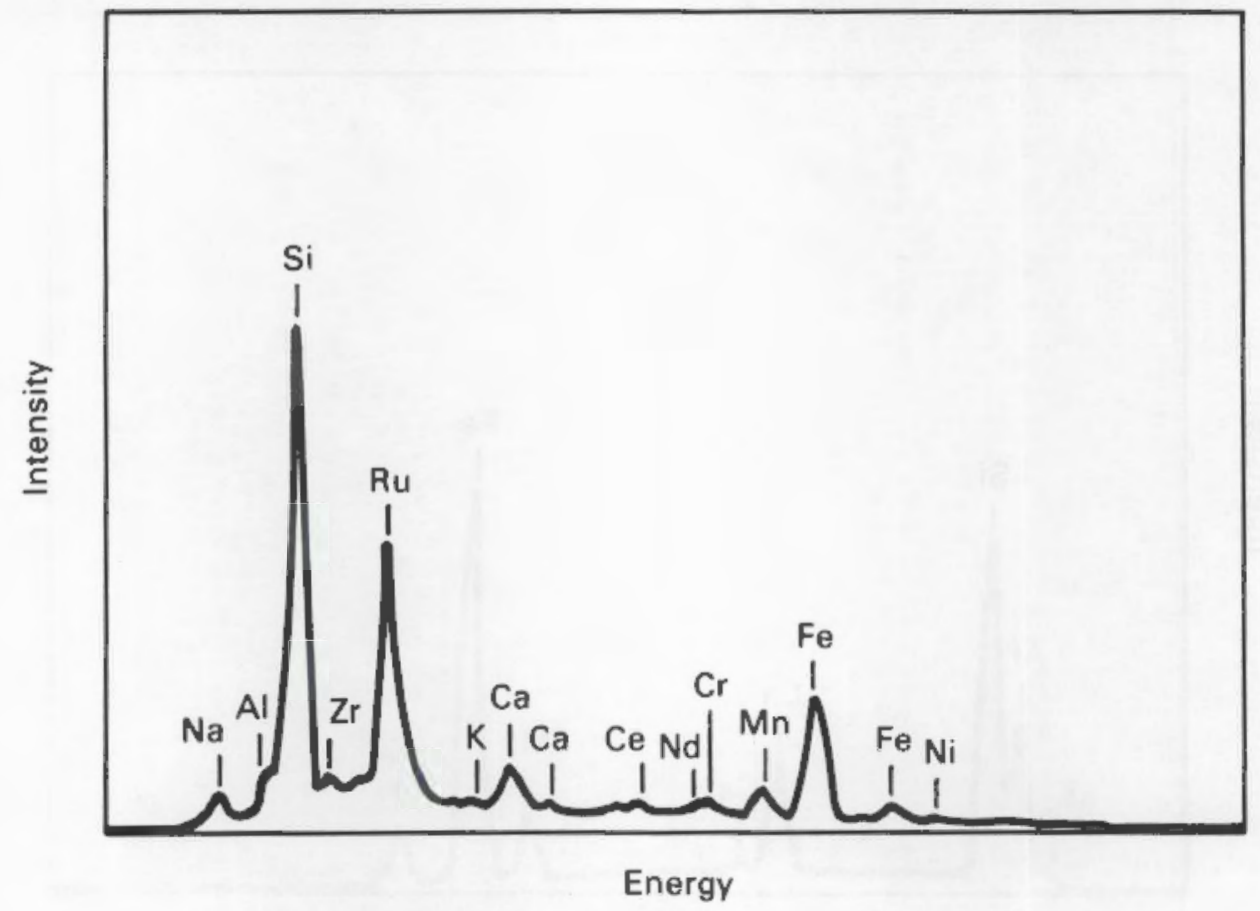

FIGURE 26. EDX Spectra of Feature 1 in Figure 25 
This feed composition was run in the ECM during ECM-84-4 and ECM-84-5A through $5 C$, and the PSCM during PSCM-19/19E. The crucible was not dry-fed; the glass remaining from LFMM-86-5 was used as the starting base glass. It should be noted that the feed was slightly off target $\left(\mathrm{CeO}_{2}\right.$ and $\left.\mathrm{Re}_{2} \mathrm{O}_{3}\right)$, but this should not have affected the melting behavior. The conditions and results for LFMM-88-6 are listed in Table 8.

This feed processed more slowly than the "no sugar" feed run in LFMM-86-5. The cold cap appearance was also different. The cold cap was darker and tended to form taller towers. This tower formation was observed during ECM-84-4 and 5 and PSCM-19/19E. A thick, viscous phase surrounded the cold cap and appeared to be more viscid (less venting activity seen) than the material seen in LFMM-86-5. A viscous, insoluble phase had formed in the ECM and PSCM runs; this phase grew worse with increased sugar levels, as was observed in LFMM-86-6.

The "sugared" feed did process more slowly in the LFMM, but a very large difference between the two feeds was not seen. As noted for the LFMM-86-5 run, the nominal and maximum feed rates of the sugared WV 182 feed were also difficult to determine due to the cold cap appearance.

Analyses of the feed samples taken during the run show that minimal feed settling occurred in the feed lines. Analyses of the glass show the ferrous/ ferric ratio to increase over time to approximately 1.7 . This ratio dropped to

\section{TABLE 8. LFMM-86-6 Run Conditions and Results}

$\begin{array}{ll}\text { Feed used } & \text { WV } 182,75 \mathrm{~g} / \mathrm{L} \text { sugar added } \\ \text { Total run time } & 17 \mathrm{~h} 55 \mathrm{~min} \\ \text { Amount of feed processed } & 8.28 \mathrm{~L} \\ \text { Amount of glass produced } & 2.23 \mathrm{~kg} \\ \text { Feed rate range } & 0.32 \text { to } 0.54 \mathrm{~L} / \mathrm{h} \\ \text { Glass production rate range } & 0.09 \text { to } 0.19 \mathrm{~kg} / \mathrm{h} \\ \text { Nominal feed rate } & 0.33 \mathrm{~L} / \mathrm{h} \\ \text { Maximum feed rate } & 0.42 \mathrm{~L} / \mathrm{h} \\ \text { Process temperature } & 1125 \mathrm{to} 1141^{\circ} \mathrm{C}\end{array}$


approximately 0.6 after $18 \mathrm{~h}$. It is not known why this occurred. Regardless, these ferrous/ferric ratios are much higher than the maximum of about 0.20 seen in PSCM-19 output glass. Figure 27 illustrates the redox response.

A sample of the surface material of the melt was sectioned, polished, and examined with SEM/EDX. No significant amounts of calcium phosphate phases, as seen in PSCM-19, were observed. This was most probably caused by the overreduced state of the LFMM glass as compared to the PSCM-19 glass. At the glass/cold cap interface, many spinel-type crystals and phases containing Ru and $\mathrm{Si}$ were observed. Figure 28 is a micrograph of this interface. Figure 29 gives EDX traces of the phases observed. The cold cap contained a high concentration of Si, with many partially dissolved silica particles. The high Si concentration in the cold cap would definitely inhibit melt rates, and serves to explain the poor melting behavior observed. Figures 30 and 31 , respectively, show a micrograph of this region and an EDX trace of the partially dissolved Si particles observed.

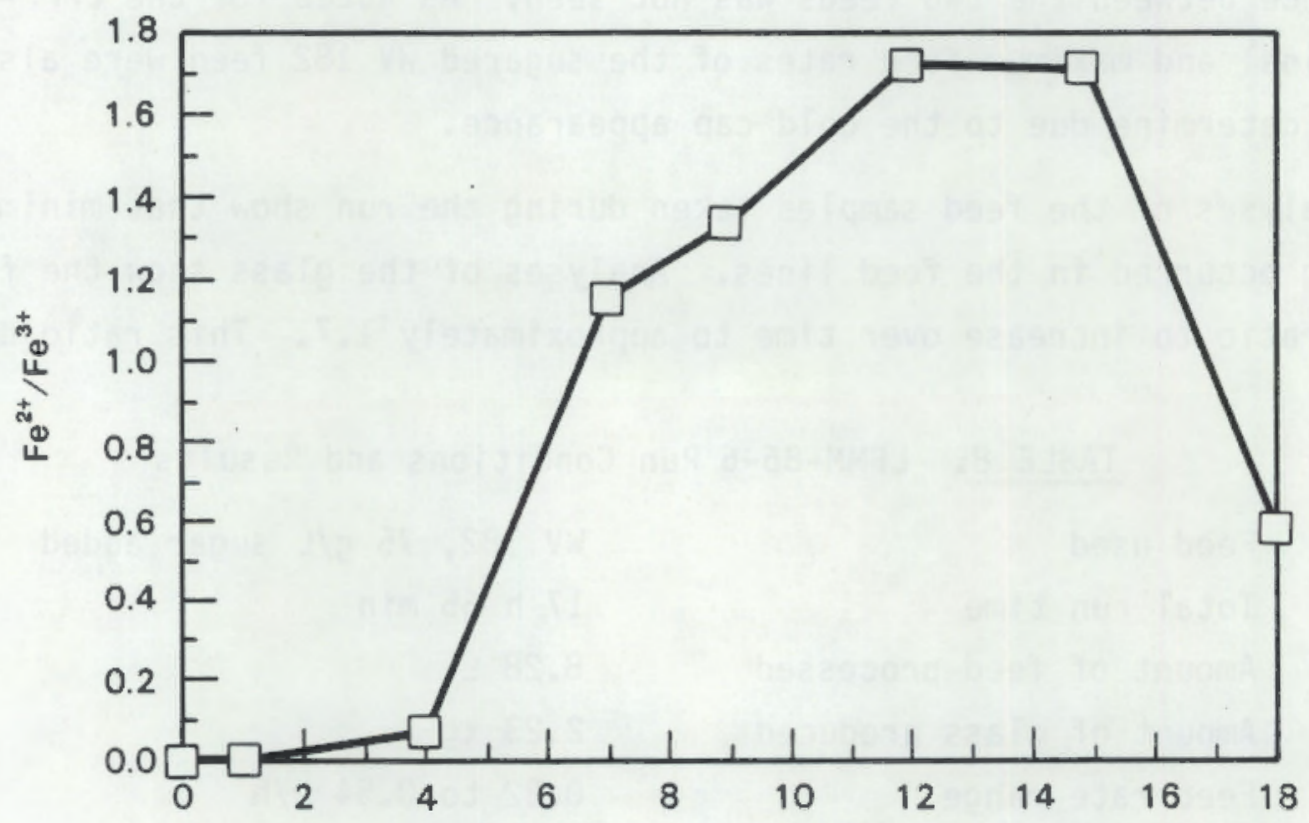

Run Time, hours

FIGURE 27. Redox Response of LFMM-86-6 Glass 


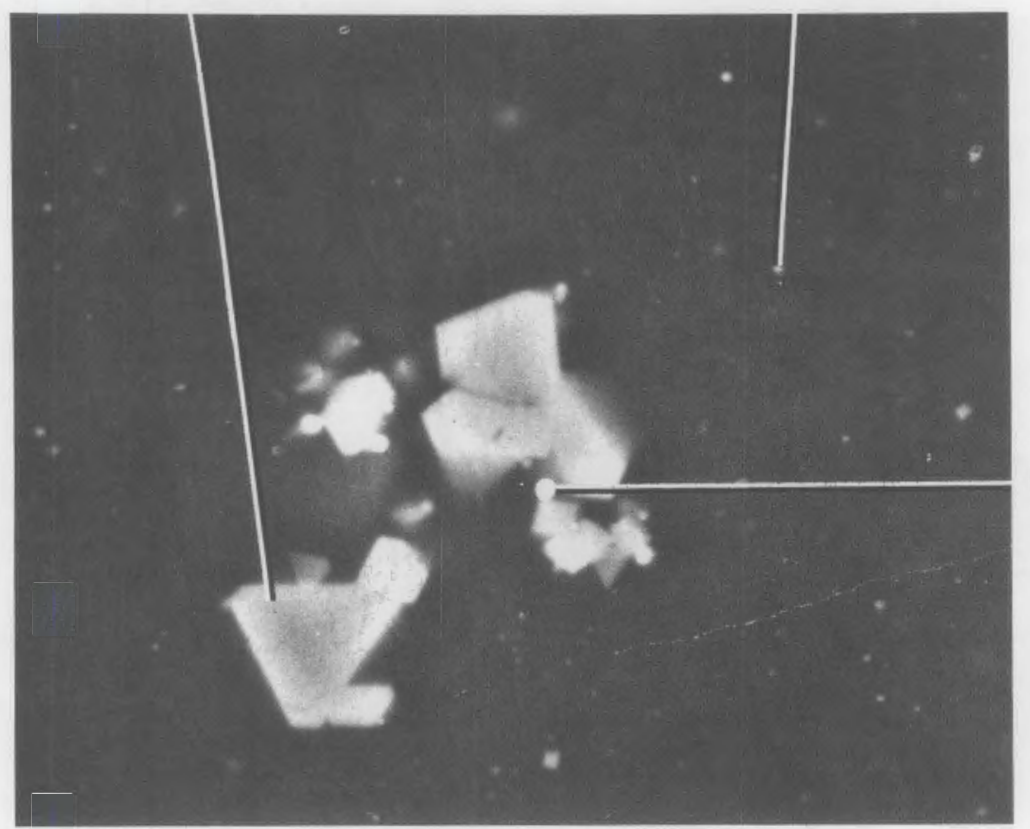

Feature 3

3000x Magnification

FIGURE 28. SEM Micrograph of LFMM-86-6 Cold Cap Interface

Examination of a thin section of output glass (sampled $10 \mathrm{~h}$ into the run) with optical microscopy and SEM/EDX revealed the presence of many crystals high in $\mathrm{Cr}$, $\mathrm{Fe}$, and $\mathrm{Ni}$. These cubic spinel-type crystals measured approximately 2.5 to 26 microns across. A few Ru-containing crystals were also present. Figure 32 shows an SEM micrograph of the glass. The amount of crystal formation in the output glass was shown to increase with more reducing conditions during PSCM-19/19E. This behavior is seen again here. Figure 33 shows an EDX trace of the spinel-type crystal observed. 

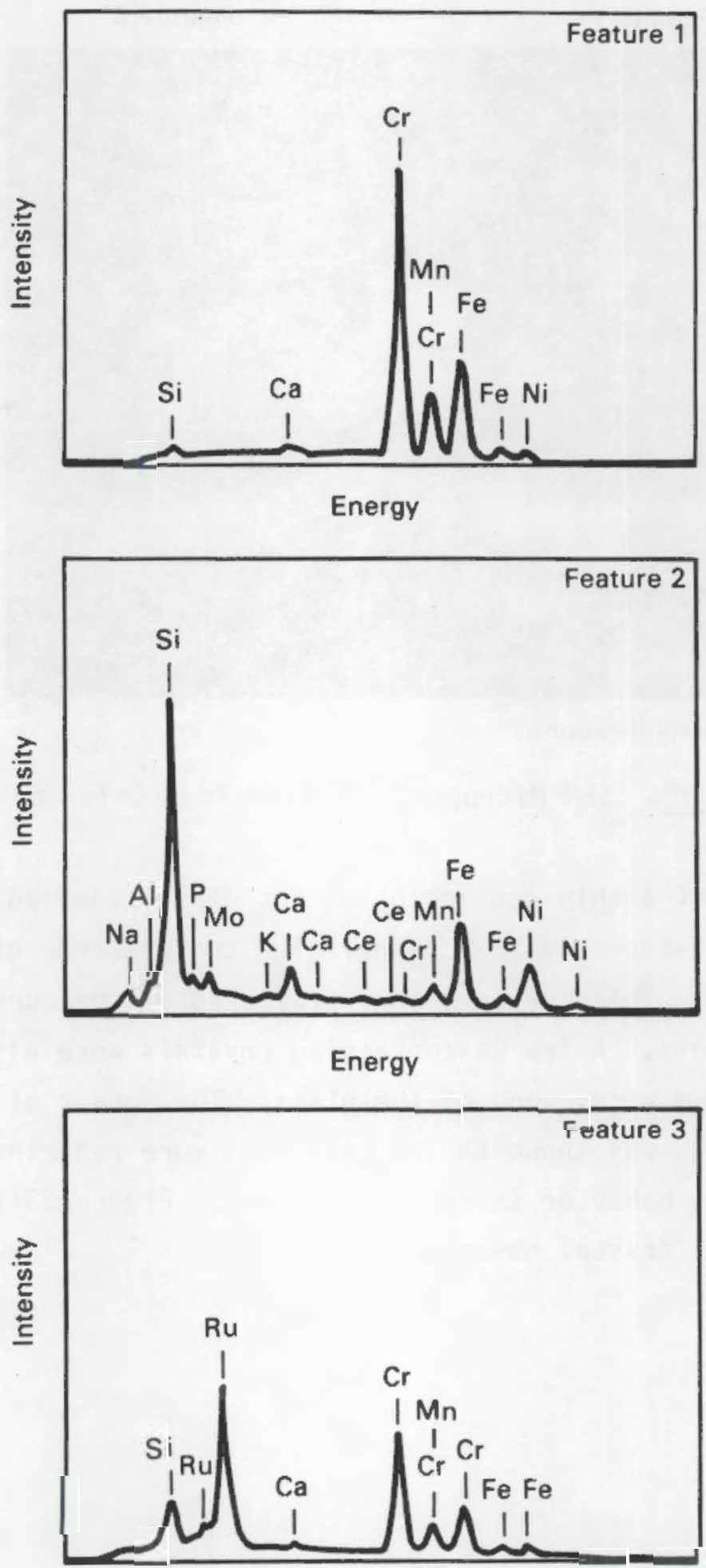

Energy

FIGURE 29. EDX Spectra of Features in Figure 28 
Feature 1

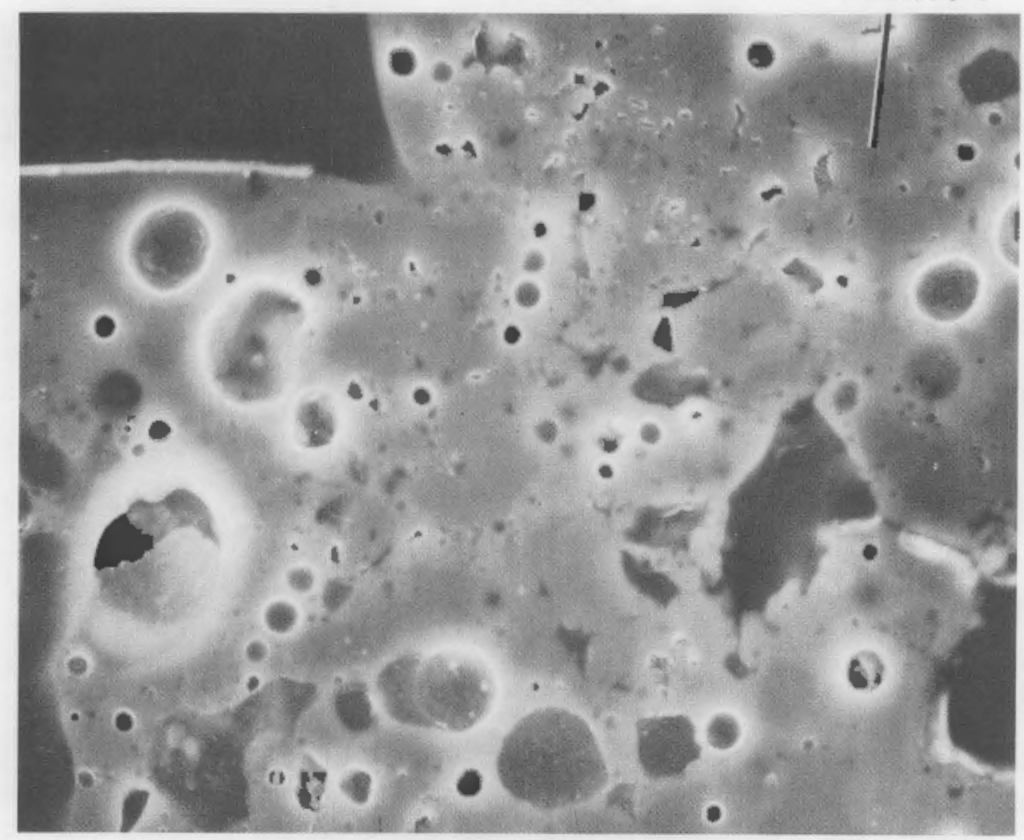

$1000 x$ Magnification

FIGURE 30. SEM Micrograph of LFMM-86-6 Cold Cap

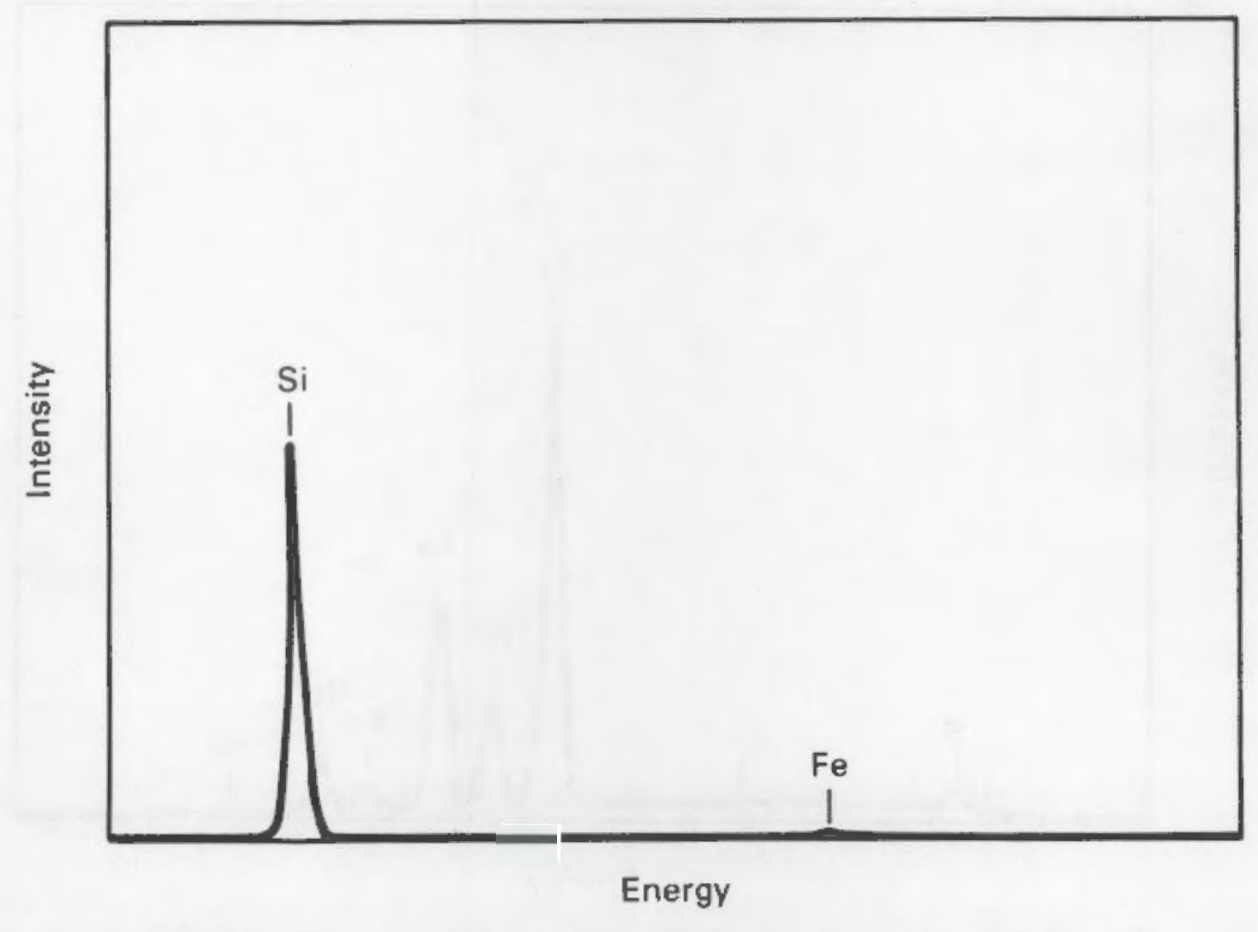

FIGURE 31. EDX Spectra of Feature 1 in Figure 30 


\section{Feature 1}

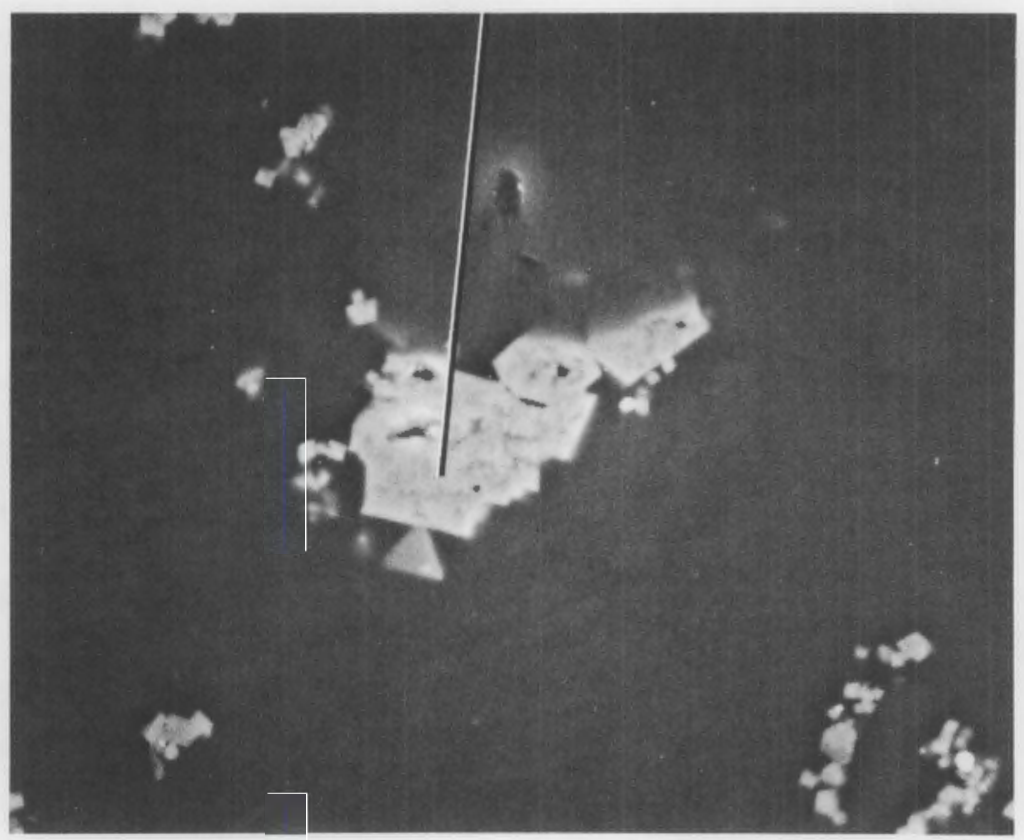

1000x Magnification

FIGURE 32. SEM Micrograph of LFMM-86-6 Output Glass (10 $\mathrm{h}$ into Run)

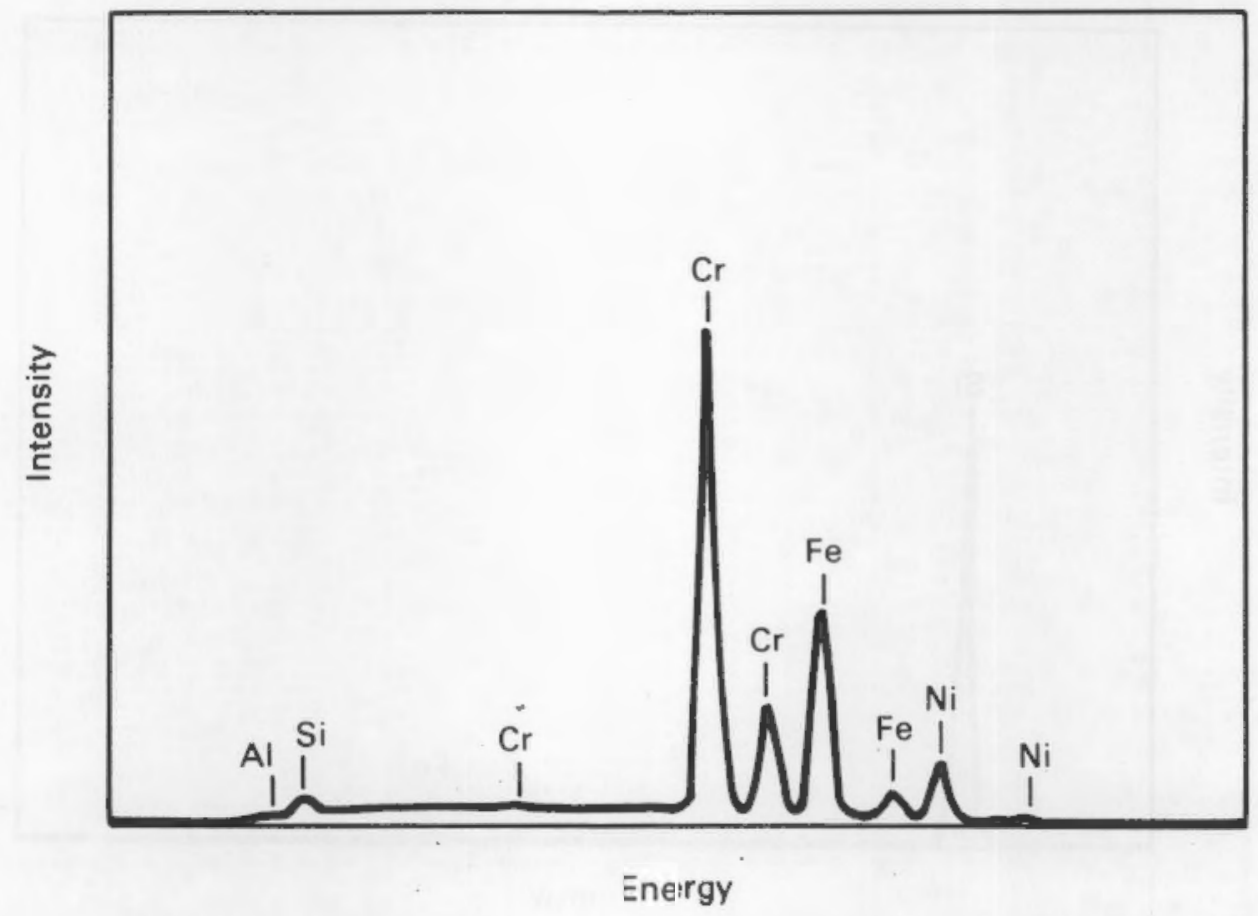

FIGURE 33. EDX Spectra of Feature 1 in Figure 32 


\section{FEED RATE CORRELATIONS}

Attempts were made to correlate the feed rates achieved in the LFMM to those of the PNL developmental joule-heated melters. Nominal and maximum feed rates as determined in the LFMM were compared to feed rates obtained in the engineering- and pilot-scale melters.

MAXIMUM FEED RATE CORRELATIONS

Data were available from HBCM and PSCM runs for three of the feeds run in the LFMM. These data are compared in Table 9 with the LFMM runs with the corresponding feeds.

Figure 34 compares the maximum feed rates achieved in the large-scale melters (specifically the HBCM and PSCM) with the maximum feed rates achieved in the LFMM. A positive correlation is seen for both melters. The lines drawn represent the "best fit" as determined by linear least-squares regression. Table 10 gives the regression parameters and equations with best fit. The slope of the PSCM correlation is greater than that of the HBCM correlation. This is expected, as the PSCM has a greater surface area and volume available for melting than does the $\mathrm{HBCM}$. The $\mathrm{R}^{2}$ values indicate that the PSCM

TABLE 9. Maximum Feed Rates Achieved by PNL Melters with Feeds Run in the LFMM

\begin{tabular}{|c|c|c|c|c|c|c|}
\hline \multirow[b]{2}{*}{ Feed } & \multicolumn{6}{|c|}{ Maximum Feed Rate, L/h } \\
\hline & $\overline{\text { LFMM }}$ & Run & $\mathrm{HBCM}$ & Run & $\mathrm{PSCM}$ & Run \\
\hline SRL-TDSF-131 & 0.55 & $86-1$ & 15.50 & $86-1$ & 62.0 & $\mathrm{PSCM}-4$ \\
\hline $\begin{array}{l}\text { Aged PSCM-22 } \\
\text { (w/sugar) }\end{array}$ & 0.34 & $86-2$ & 13.70 & $85-1$ & 39.1 & PSCM-22 \\
\hline $\begin{array}{l}\text { HWVP-RF, (a) as } \\
\text { run in HBCM- } 86-2 \text {, } \\
400 \mathrm{~g} / \mathrm{L} \text { oxides, } \\
\text { no sugar }\end{array}$ & 0.49 & $86-3$ & 18.90 & $86-2$ & 50.9 & PSCM-22 \\
\hline
\end{tabular}

(a) Hanford Waste Vitrification Program reference feed (HWVP-RF). 


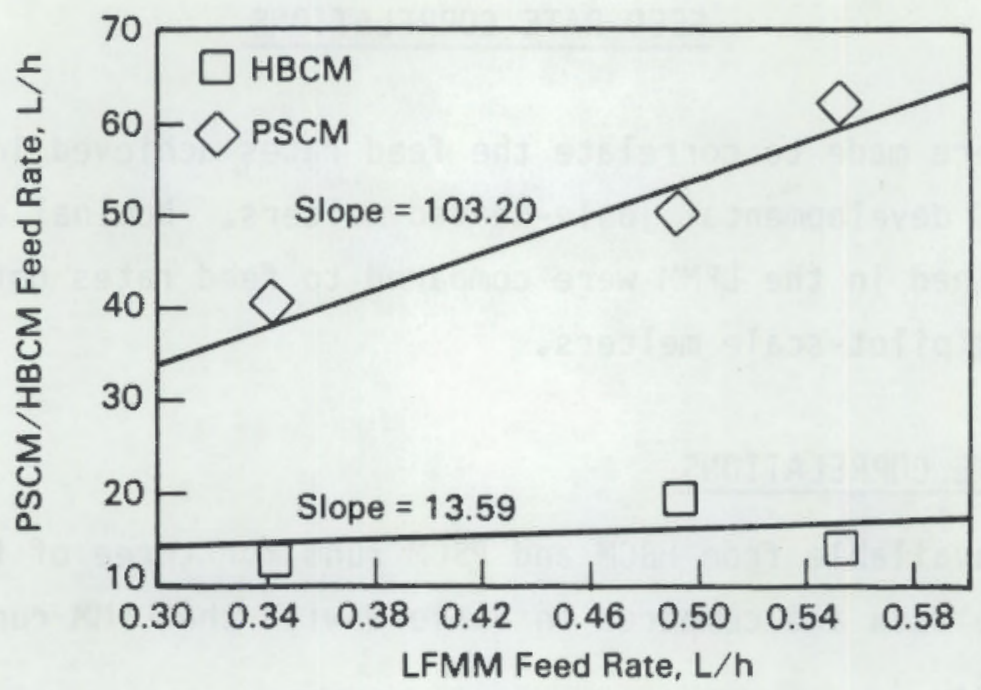

FIGURE 34. Maximum Feed Rate Correlations Between the PSCM/HBCM and the LFMM

TABLE 10. Maximum Feed Rate Correlations With LFMM

\begin{tabular}{llll} 
Melter & Equation & $\frac{R^{2}}{0.31}$ \\
\cline { 2 - 2 } & $F_{H}=13.59 * F_{L}+9.76$ & 0.95
\end{tabular}

$\begin{aligned} & F_{H}= H B C M \text { maximum feed rate, } F_{P}=\text { PSCM maximum } \\ & \text { feed rate, } F_{L}=\text { LFMM maximum feed rate. }\end{aligned}$

correlation is better than the HBCM correlation. The equation derived for the HBCM-LFMM correlation could not be used with confidence for predicting maximum feed rates in the HBCM from LFMM data. The PSCM-LFMM correlation could be used with reasonable confidence. It should be noted here that the regressions are based on three data points only, and that more data must be collected to establish true confidence in predicting maximum feed rates from LFMM feed rates.

Figure 35 compares the normalized (with respect to melt surface area) maximum feed rates achieved by the melters as a function of feed. The normalized feed rates achieved in the PSCM and HBCM are much lower than those achieved in the LFMM because of the large differences in melt surface area. The relative magnitudes of the feed rates, as related to specific melters, compare reasonably well as a function of feed. The ratio of normalized maximum 


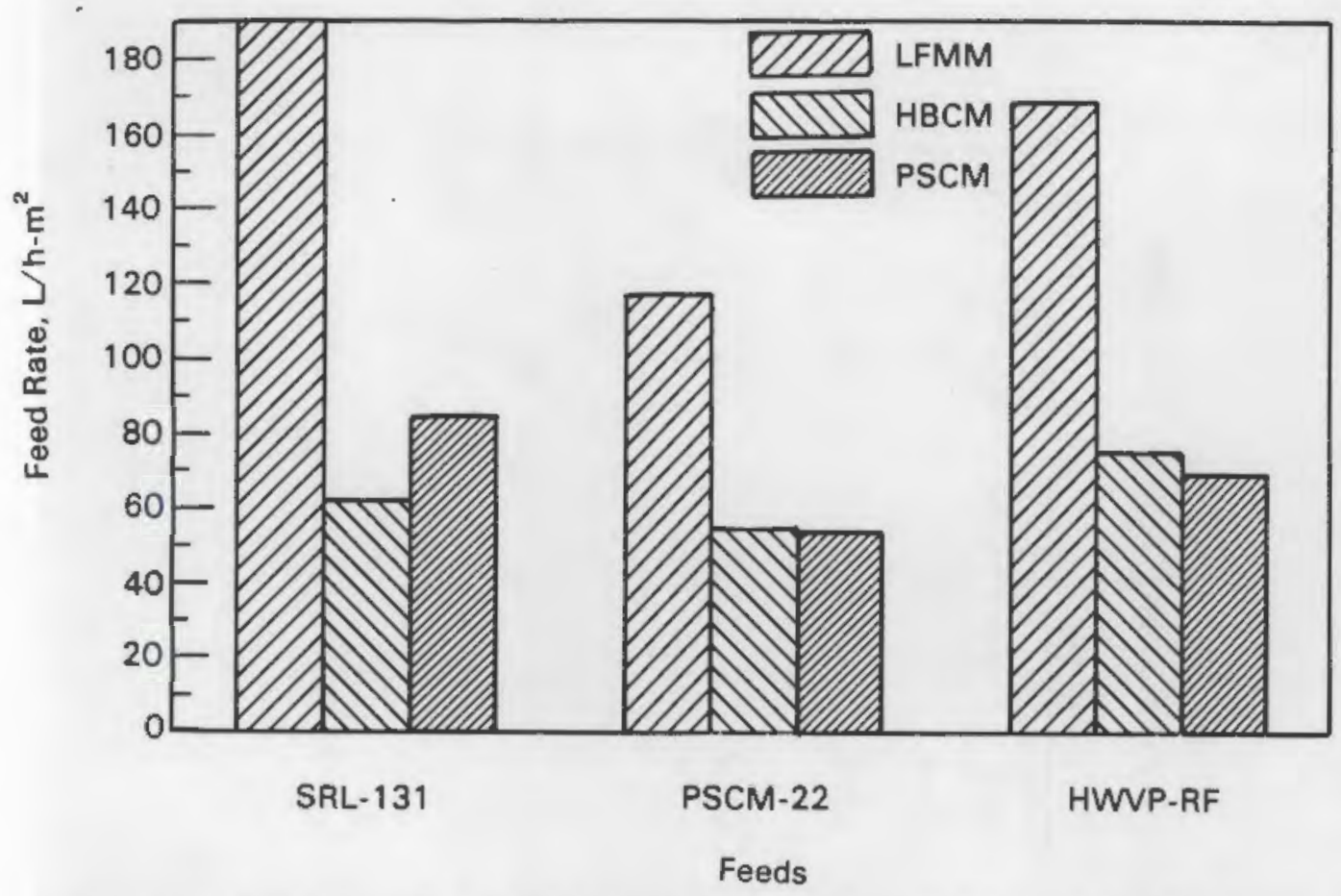

FIGURE 35. Normalized Maximum Feed Rates Achieved by Melters

feed rates achieved in the LFMM to those obtained in the HBCM and PSCM are $2.47 \pm 0.51$ and $2.27 \pm 0.12$, respectively. The LFMM correlates better with the PSCM than the HBCM in this analysis (smaller standard deviation), as was also noted for the linear feed rate correlations described earlier.

\section{NOMINAL FEED RATE CORRELATIONS}

The data used for the nominal feed rate correlations are listed in Table 11. The runs and feeds are identified.

Figure 36 plots the nominal feed rates achieved in the engineering-scale melters against the nominal rates achieved in the LFMM. Positive correlations are seen for all melters (ECM, HBCM, PSCM). The equations derived from linear least-squares regression are given in Table 12.

As evidenced by the $R^{2}$ values in Table 12, these correlations are rather poor; the best correlation was obtained for the ECM. This is caused by the large amount of scatter seen in the data. Some scatter was expected, as the data are based on observation of melt surfaces and will be influenced by the 
TABLE 11. Nominal Feed Rates Achieved by Melters with Feeds Run in the LFMM

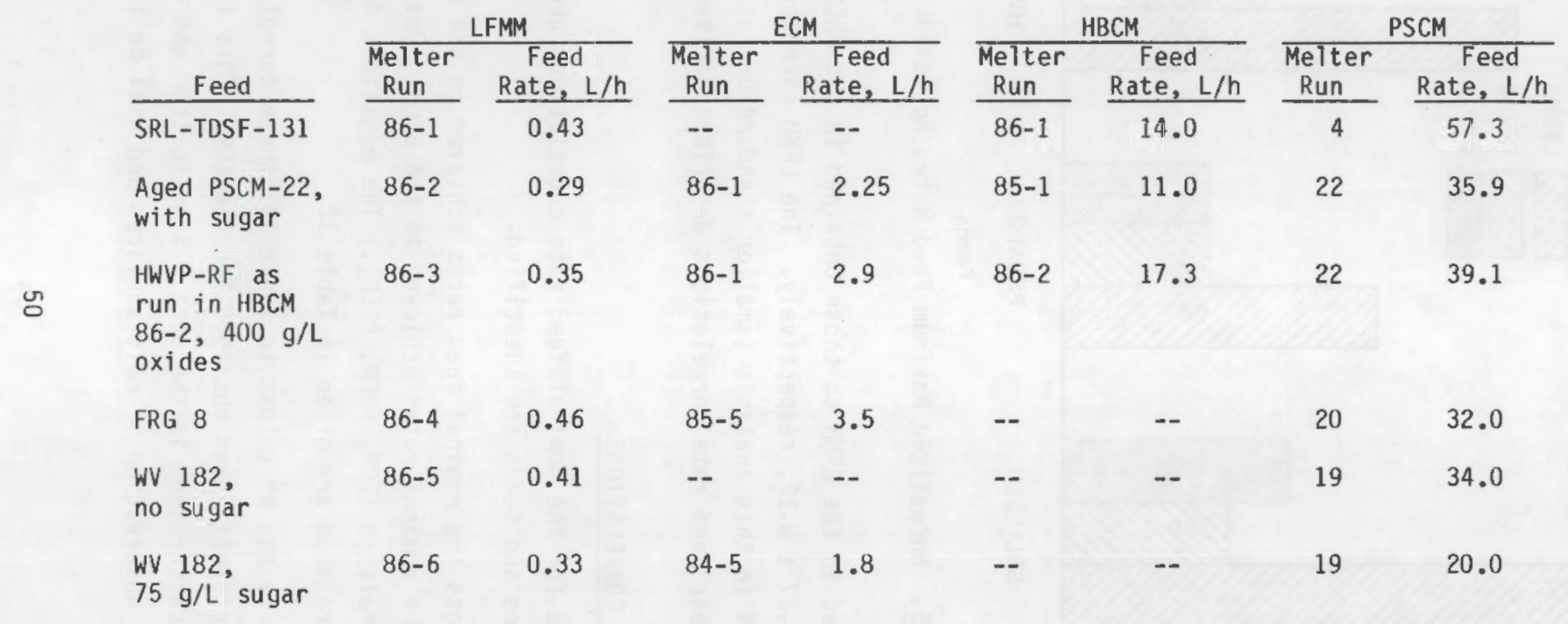



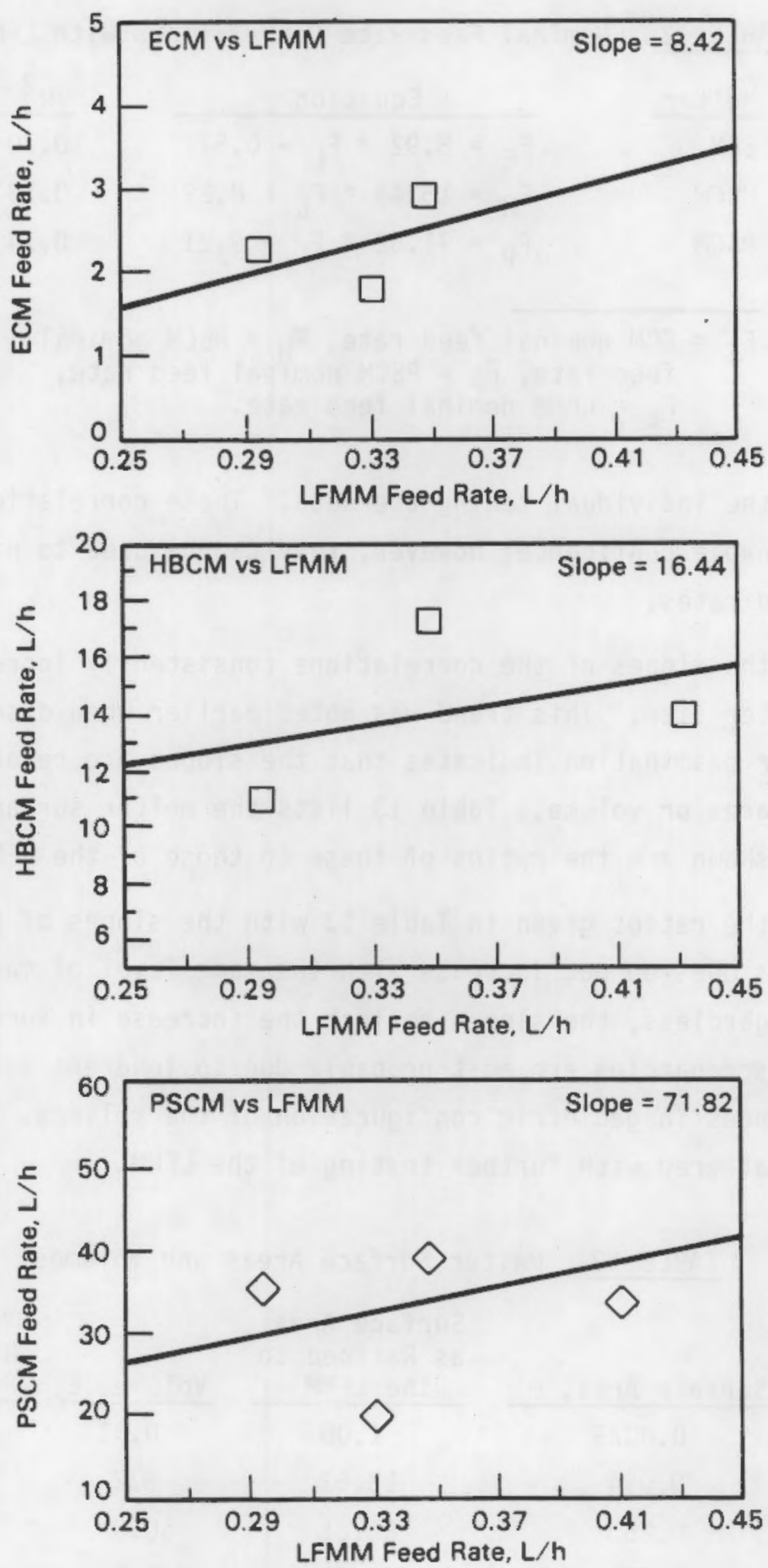

FIGURE 36. Nominal Feed Rate Correlations Between the ECM, HBCM, PSCM and the LFMM 
TABLE 12. Nominal Feed Rate Correlations With LFMM

$\begin{array}{llll}\text { Melter } & & \frac{R^{2}}{0.70 u a t i o n} & 0.70 \\ \text { ECM } & F_{E}=8.92 * F_{L}-0.57 & 0.13 \\ \text { HBCM } & F_{H}=16.44 * F_{L}+8.22 & 0.14 \\ \text { PSCM } & F_{P}=71.82 * F_{L}+9.21 & 0\end{array}$

\footnotetext{
$F_{E}=E C M$ nominal feed rate, $F_{H}=H B C M$ nominal feed rate, $F_{P}=$ PSCM nominal feed rate, $F_{L}=$ LFMM nominal feed rate.
}

objectivity of the individual taking the data. These correlations cannot be used with reasonable confidence; however, they can be used to pinpoint a range of expected feed rates.

Note that the slopes of the correlations consistently increase with increase in melter size. This trend was noted earlier when discussing Figure 34. Further examination indicates that the slopes are related to specific melter surface area or volume. Table 13 lists the melter surface areas and volumes. Also shown are the ratios of these to those of the LFMM.

Comparing the ratios given in Table 13 with the slopes of the correlations shows that the slopes do not increase with the same level of magnitude as do the ratios. Regardless, the slopes reflect the increase in surface area and volume. The discrepancies are most probably due to inherent scale-up factors and the differences in geometric configuration of the melters. Further information can be gathered with further testing of the LFMM.

TABLE 13. Melter Surface Areas and Volumes

\begin{tabular}{|c|c|c|c|c|}
\hline Melter & Surface Area, $\mathrm{m}^{2}$ & $\begin{array}{l}\text { Surface Area } \\
\text { as Ratioed to } \\
\text { the LFMM } \\
\end{array}$ & Volume, L & $\begin{array}{l}\text { Volume as } \\
\text { Ratioed to } \\
\text { the LFMM } \\
\end{array}$ \\
\hline LFMM & 0.0029 & 1.00 & 0.31 & 1.00 \\
\hline ECM & 0.054 & 18.62 & 8.2 & 26.71 \\
\hline $\mathrm{HBCM}$ & 0.25 & 86.21 & 50.0 & 162.87 \\
\hline PSCM & 0.73 & 251.72 & 290.0 & 944.62 \\
\hline
\end{tabular}


Figure 37 compares the nominal feed rates achieved by the melters, normalized with respect to melt surface area, as a function of feed. The relative magnitudes of the feed rates, as related to specific melters, compare reasonably well as a function of feed. The ratio of normalized nominal feed rates achieved in the LFMM to those obtained in the ECM, HBCM, and PSCM are $2.62 \pm$ $0.56,2.22 \pm 0.45$, and $2.83 \pm 0.94$, respectively. The ratio of LFMM:HBCM is smaller than the ratio of LFMM:PSCM. This situation is the reverse of that observed when comparing the normalized maximum feed rates. One would expect them to be relatively similar. More data need to be collected and analyzed to resolve this discrepancy. 

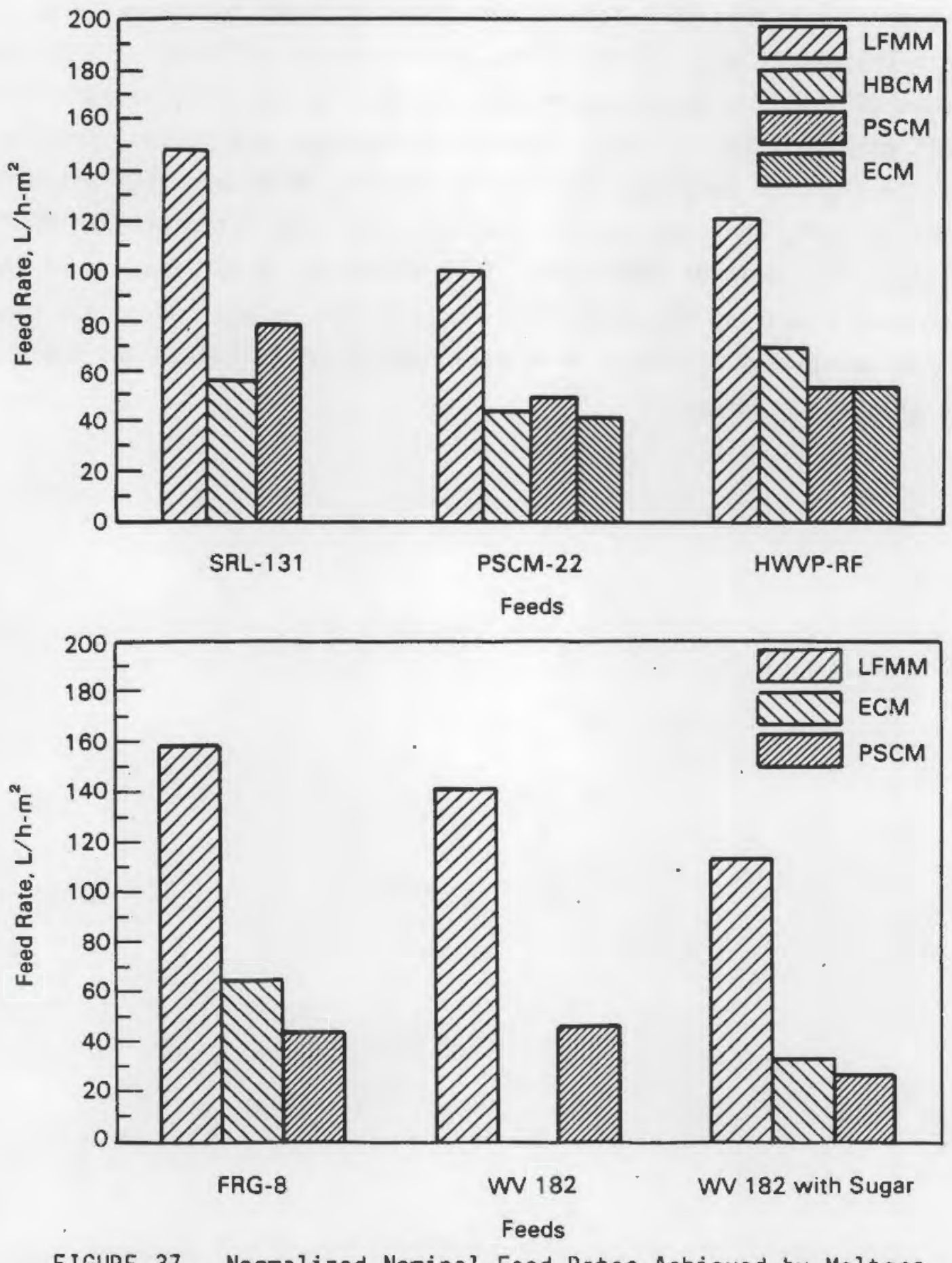

FIGURE 37. Normalized Nominal Feed Rates Achieved by Melters 


\section{REFERENCES}

Burkholder, H. C., and J. H. Jarrett. 1985. Commercial LFCM Vitrification Technology. PNL-5470-1, Pacific Northwest Laboratory, Richland, Washington.

Burkholder, H. C., J. H. Jarrett, and J. E. Minor. 1985. LFCM Vitrification Technology. PNL-5470-2, Pacific Northwest Laboratory, Richland, Washingtion.

Goldman, D. S. 1985. "Melting Process Chemistry." In Commercial LFCM Vitrification Technology, H. C. Burkholder and J. H. Jarrett, compilers. PNL-5470-1, Pacific Northwest Laboratory, Richland, Washington.

Goldman, D. S., L. A. Chick, and H. T. Blair. 1985. "Melting Process Chemistry and Glass Development." In LFCM Vitrification Technology, H. C. Burkholder, J. H. Jarrett, and J. E. Minor, compilers. PNL-5470-2, Pacific Northwest Laboratory, Richland, Washington.

Gombert II, D. 1979. "A Laboratory-Scale Glass Melter for Testing Defense Waste Glass." In Ceramics in Nuclear Waste Management. CoNF-790420, National Technical Information Service, U.S. Department of Commerce, Springfield, Virginia.

Harmon, K. M., L. T. Lakey, and I. W. Leigh. 1984. Summary of National and International Fuel Cycle and Radioactive Waste Management Programs: 1984. PNL-5138, Pacific Northwest Laboratory, Richland, Washington.

Plodinec, M. J., and P. H. Chismar. 1979. Small-Scale, Joule-Heated Melting of Savannah River Plant Waste Glass, I. Factors Affecting Large-Scale Vitrification Tests. OP-1535, Savannah River Laboratory, Aiken, South Carolina.

U.S. DOE. 1982. The Evaluation and Selection of Candidate High-Level Waste Forms. DOE/TIC-11611, Savannah River Operations Office, Aiken, South Carolina.

Westsik, J. H., et al. 1985. Instrumentation for Remote Monitoring and Control of Liquid-Fed Ceramic Melters. PNL-5635, Pacific Northwest Laboratory, Richland, Washington. 


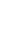




\section{APPENDIX}

LFMM FEED COMPOSITIONS AND FEED AND GLASS ANALYSES 
TABLE A.1. SRL-TDSF-131 Feed Composition (LFMM-86-1 Feed)

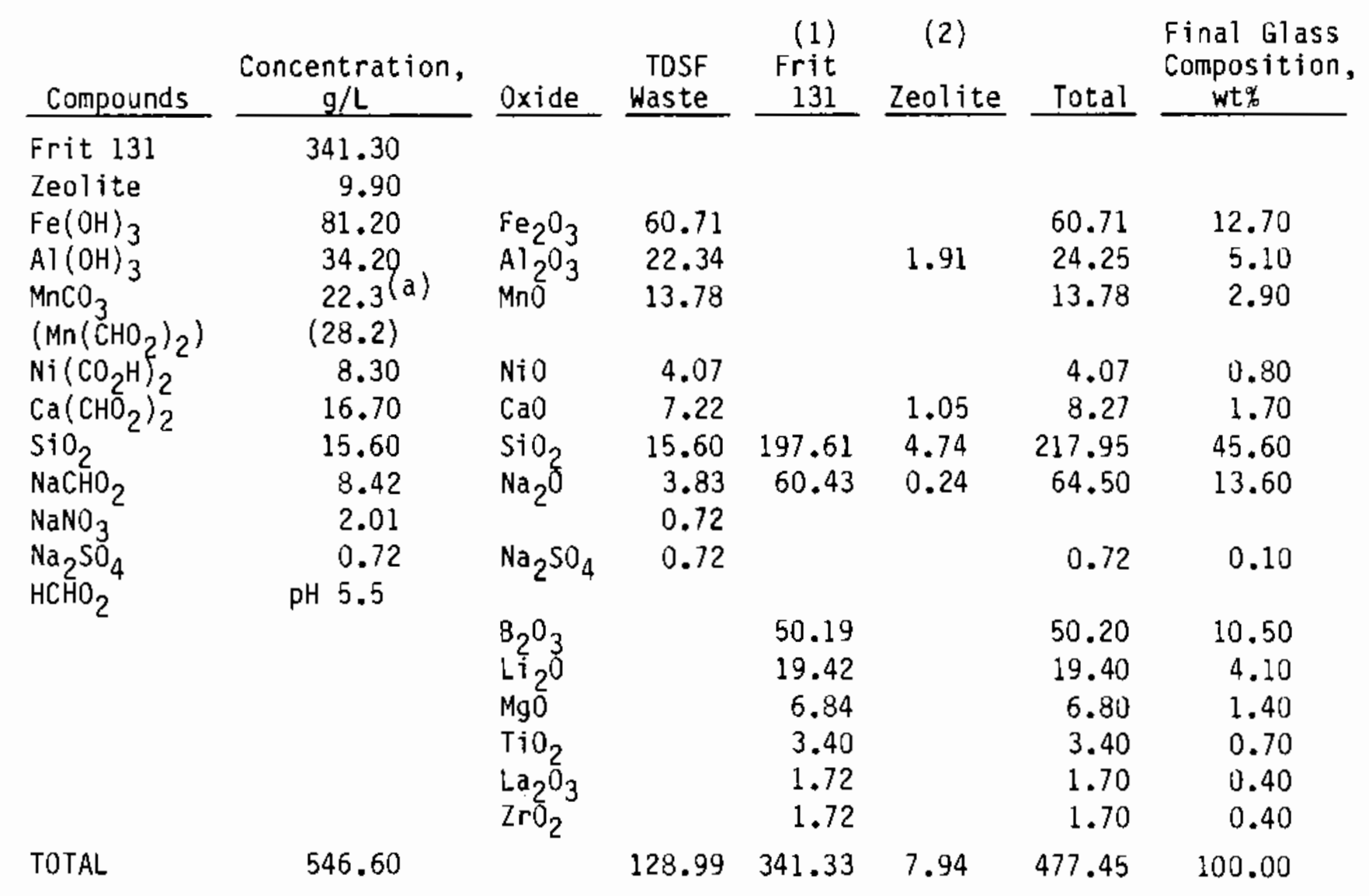

(a) Value based on reaction of $\mathrm{MnCO}_{3}$ and $\mathrm{MCHO}_{2}$.

(1) Frit-131 Composition (-200 mesh)

(2) Zeolite Composition (Linde Ionsiv IE-95)

\begin{tabular}{|c|c|c|c|}
\hline Oxide & $w t \%$ & Component & $\mathrm{wt} \%$ \\
\hline $\mathrm{SiO}_{2}$ & 57.9 & $\mathrm{CaAl}_{2} \mathrm{Si}_{4} \mathrm{O}_{12} \cdot 6 \mathrm{H}_{2} \mathrm{O}$ & 80.0 \\
\hline $\mathrm{B}_{2} \mathrm{O}_{3}$ & 14.7 & $\mathrm{NaCa}_{1} \cdot 5 \mathrm{~A}_{13} \mathrm{Si}_{8} \mathrm{O}_{24} \cdot 8 \mathrm{H}_{2} \mathrm{O}$ & 20.0 \\
\hline $\mathrm{Na}_{2} \mathrm{O}$ & 17.7 & & \\
\hline $\mathrm{Li}_{2} \mathrm{O}$ & 5.7 & Assumed 0xide Form & \\
\hline Mgố & 2.0 & & \\
\hline $\mathrm{TiO}_{2}$ & 1.0 & $\mathrm{CaO}$ & 10.6 \\
\hline $\mathrm{La}_{2} \mathrm{O}_{3}$ & 0.5 & $\mathrm{Al}_{2} \mathrm{O}_{3}$ & 19.2 \\
\hline \multirow[t]{2}{*}{$2 \mathrm{rO}_{2}{ }^{\mathrm{S}}$} & 0.5 & $\mathrm{SiO}_{2} \mathrm{C}$ & 47.7 \\
\hline & & $\mathrm{Na}_{2} \mathrm{O}$ & 2.5 \\
\hline \multirow[t]{2}{*}{ Total } & 100.0 & $\mathrm{H}_{2} \mathrm{O}$ & 20.0 \\
\hline & & Total & 100.0 \\
\hline
\end{tabular}


TABLE A.2. ICP Analyses of Feed Sarmples Taken During LFMM-86-1

\begin{tabular}{|c|c|c|c|c|c|c|c|c|c|c|c|c|}
\hline \multirow{2}{*}{$\begin{array}{l}\text { Hours } \\
\text { Into Run } \\
\text { Sample } \\
\text { Number } \\
\text { Oxide } \\
\end{array}$} & \multicolumn{2}{|c|}{$\begin{array}{c}1.03 \\
1 \\
\end{array}$} & \multicolumn{2}{|c|}{$\begin{array}{c}2.00 \\
2 \\
\end{array}$} & \multicolumn{2}{|c|}{5.70} & \multicolumn{2}{|c|}{8.70} & \multicolumn{2}{|c|}{ Bulk (a) } & \multicolumn{2}{|c|}{ Target } \\
\hline & $\begin{array}{c}9 / L \\
\text { oxides } \\
\end{array}$ & $w t \%$ & $\begin{array}{c}\mathrm{g} / \mathrm{L} \\
\text { 0xides }\end{array}$ & $w t \%$ & $\begin{array}{c}\mathrm{g} / \mathrm{L} \\
0 x i d e s \\
\end{array}$ & $w t \%$ & $\begin{array}{c}\mathrm{g} / \mathrm{L} \\
\text { 0xides } \\
\end{array}$ & $w t \%$ & $\begin{array}{c}\mathrm{g} / \mathrm{L} \\
\text { 0xides } \\
\end{array}$ & $w t \%$ & $\begin{array}{c}\mathrm{g} / \mathrm{L} \\
\text { 0xides } \\
\end{array}$ & wt\% \\
\hline $\mathrm{A}_{2}{ }_{2} \mathrm{O}_{3}$ & 26.30 & 5.30 & 27.00 & 5.31 & 26.00 & 5.32 & 26.30 & 5.33 & 25.80 & 5.16 & 24.25 & 5.10 \\
\hline $\mathrm{B}_{2} \mathrm{O}_{3}$ & 50.80 & 10.24 & 51.80 & 10.18 & 49.80 & 10.18 & 50.30 & 10.20 & 51.10 & 10.22 & 50.20 & 10.50 \\
\hline $\mathrm{CaO}$ & 9.35 & 1.88 & 9.85 & 1.94 & 9.32 & 1.91 & 9.35 & 1.90 & 9.53 & 1.91 & 8.27 & 1.70. \\
\hline $\mathrm{Fe}_{2} \mathrm{O}_{3}$ & 67.20 & 13.55 & 68.80 & 13.52 & 66.00 & 13.49 & 66.60 & 13.50 & 67.20 & 13.44 & 12.70 & 13.44 \\
\hline $\mathrm{La}_{2} \mathrm{O}_{3}$ & 1.53 & 0.31 & 1.57 & 0.31 & 1.51 & 0.31 & 1.54 & 0.31 & 1.35 & 0.27 & 1.70 & 0.40 \\
\hline $\operatorname{Li}_{2} 0$ & 19.80 & 3.99 & 20.00 & 3.93 & 19.20 & 3.93 & 19.50 & 3.95 & 18.35 & 3.67 & 19.40 & 4.10 \\
\hline MgO & 6.75 & 1.36 & 6.94 & 1.36 & 6.64 & 1.36 & 6.81 & 1.38 & 5.58 & 1.12 & 6.80 & 1.40 \\
\hline $\mathrm{MnO}$ & 17.10 & 3.45 & 17.50 & 3.44 & 16.70 & 3.41 & 16.80 & 3.41 & 13.97 & 2.79 & 13.78 & 2.90 \\
\hline $\mathrm{Na}_{2} \mathrm{O}$ & 70.40 & 14.19 & 72.20 & 14.19 & 69.20 & 14.15 & 69.20 & 14.03 & 70.65 & 14.13 & 64.50 & 13.60 \\
\hline $\mathrm{NiO}$ & 3.41 & 0.69 & 3.46 & 0.68 & 3.36 & 0.69 & 3.48 & 0.71 & 3.16 & 0.63 & 4.07 & 0.80 \\
\hline $\mathrm{SiO}_{2}$ & 218.00 & 43.94 & 224.00 & 44.03 & 216.00 & 44.16 & 218.00 & 44.20 & 228.00 & 45.60 & 217.95 & 45.60 \\
\hline $\mathrm{TiO}_{2}$ & 3.66 & 0.74 & 3.74 & 0.74 & 3.58 & 0.73 & 3.60 & 0.73 & 3.62 & 0.72 & 3.40 & 0.70 \\
\hline $\mathrm{ZrO}_{2}$ & 1.78 & 0.36 & 1.90 & 0.37 & 1.79 & 0.37 & 1.76 & 0.36 & 1.73 & 0.34 & 1.70 & 0.40 \\
\hline TOTAL & 496.08 & 100.00 & 508.76 & 100.00 & 489.10 & 100.00 & 493.24 & 100.00 & 500.02 & 100.00 & 477.45 & 100.00 \\
\hline
\end{tabular}

(a) Analysis of feed as received. 
TABLE A.3. Normalized Compositions of Glass Samples Taken During LFMM-86-1 (Analysis performed by ICP)

Hours

Normalized Weight Percent

Into

\begin{tabular}{|c|c|c|c|c|c|c|c|c|c|}
\hline Run & & 1.00 & 2.67 & 3.83 & 7.33 & 10.33 & 13.33 & & \\
\hline Oxide & $\begin{array}{l}\text { Starting } \\
\text { Glass } \\
\end{array}$ & $\# 1$ & $\# 2$ & $\# 3$ & $\# 4$ & $\# 5$ & $\# 6$ & $\begin{array}{l}\text { Bulk } \\
\text { Feed }\end{array}$ & Taryet \\
\hline $\mathrm{O}_{3}$ & 5.16 & 5.23 & 5.21 & 5.19 & 5.16 & 5.16 & 5.18 & 5.16 & 5.10 \\
\hline & 9.89 & 9.84 & 9.92 & 9.89 & 9.99 & 9.93 & 9.92 & 10.22 & 10.50 \\
\hline & 1.93 & 1.92 & 1.87 & 1.88 & 1.86 & 1.84 & 1.86 & 1.91 & 1.70 \\
\hline $\mathrm{Fe}_{2} \mathrm{O}_{3}$ & 13.67 & 13.24 & 13.33 & 13.12 & 13.13 & 13.20 & 13.23 & 13.44 & 12.70 \\
\hline $\mathrm{L}_{2} \mathrm{O}_{3}$ & 0.26 & 0.29 & 0.30 & 0.30 & 0.29 & 0.29 & 0.30 & 0.27 & 0.40 \\
\hline $\mathrm{Li}_{2} \mathrm{O}^{\circ}$ & 3.43 & 3.85 & 3.81 & 3.86 & 3.89 & 3.87 & 3.84 & 3.67 & 4.10 \\
\hline MgO & 1.10 & 1.28 & 1.28 & 1.23 & 1.26 & 1.24 & 1.28 & 1.12 & 1.40 \\
\hline Mno & 2.82 & 2.78 & 2.80 & 2.72 & 2.71 & 2.72 & 2.73 & 2.79 & 2.90 \\
\hline $\mathrm{Na}_{2} \mathrm{O}$ & 13.57 & 13.54 & 13.33 & 13.94 & 13.73 & 13.90 & 13.73 & 14.13 & 13.60 \\
\hline $\mathrm{NiO}$ & 0.69 & 0.99 & 0.94 & 0.85 & 0.77 & 0.77 & 0.74 & 0.63 & 0.80 \\
\hline $\mathrm{SiO}_{2}$ & 46.46 & 45.98 & 46.09 & 45.99 & 46.15 & 46.01 & 46.14 & 45.60 & 45.60 \\
\hline $\mathrm{TiO}_{2}$ & 0.70 & 0.70 & 0.71 & 0.70 & 0.72 & 0.72 & 0.72 & 0.72 & 0.70 \\
\hline $\mathrm{ZrO}_{2}^{2}$ & 0.32 & 0.35 & 0.33 & 0.34 & 0.34 & 0.34 & 0.34 & 0.34 & 0.40 \\
\hline TOTAL & 100.00 & 100.00 & 100.00 & 100.00 & 100.00 & 100.00 & 100.00 & 100.00 & 99.90 \\
\hline$=\mathrm{e}^{2+} / \mathrm{Fe}^{3}$ & 0.05 & 0.23 & 0.33 & 0.32 & 0.62 & 0.62 & 0.66 & & \\
\hline
\end{tabular}


TABLE A.4. Composition of Simulated Melter Feed Slurry(a) Used in LFMM-86-? Compound $(b)$ Concentration, $g / L$ Assumed 0xide Concentration, $g / L$ Glass wt\%

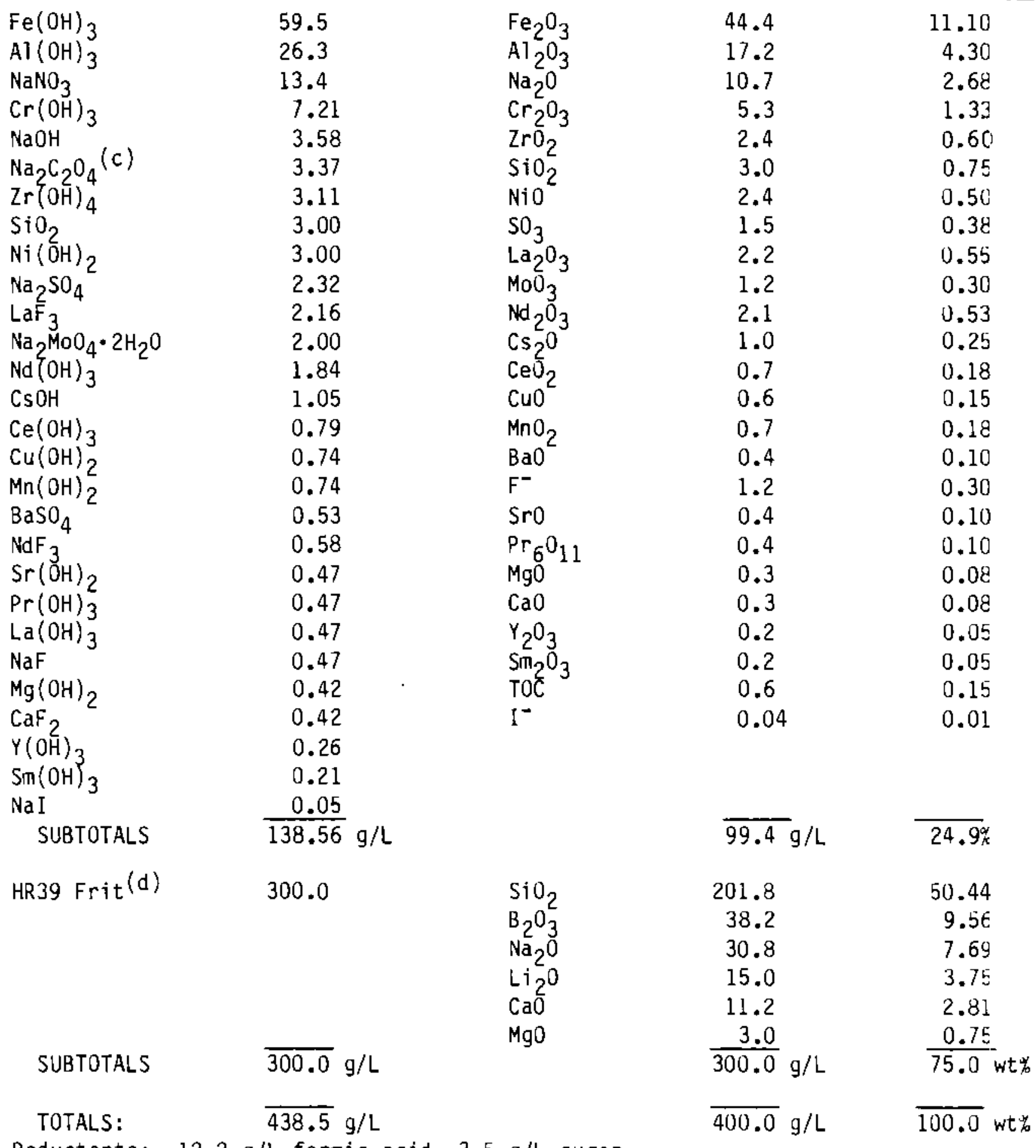

Reductants: $12.2 \mathrm{~g} / \mathrm{L}$ formic acid, $3.5 \mathrm{~g} / \mathrm{L}$ sugar

(a) Basis: $400 \mathrm{~g}$ oxide/L slurry, 25\% waste oxide loading.

(b) Prior to Reaction with Formic Acid.

(c) TOC substitute.

(d) HK39 frit size distribution as follows: $1 / 3$ to be $-80+200$ mesh

$2 / 3$ to be -200 mesh.

\section{A. 4}


TABLE A.5. Feed Sample Compositions Taken During LFMM-86-2

\begin{tabular}{|c|c|c|c|c|c|c|c|c|c|c|c|c|c|c|c|c|}
\hline \multirow{2}{*}{$\begin{array}{l}\text { Hours } \\
\text { Into Run } \\
\text { Sample } \\
\text { Number } \\
\text { Oxide } \\
\end{array}$} & \multicolumn{2}{|c|}{$\begin{array}{c}1.00 \\
1 \\
\end{array}$} & \multicolumn{2}{|c|}{$\begin{array}{c}2.12 \\
2\end{array}$} & \multicolumn{2}{|c|}{$\begin{array}{c}7.00 \\
3\end{array}$} & \multicolumn{2}{|c|}{$\begin{array}{c}10.00 \\
4\end{array}$} & \multicolumn{2}{|c|}{$\begin{array}{c}11.00 \\
5\end{array}$} & \multicolumn{2}{|c|}{$\begin{array}{c}14.00 \\
6\end{array}$} & \multicolumn{2}{|c|}{ Bulk } & \multicolumn{2}{|c|}{ Target } \\
\hline & $\begin{array}{c}9 / \mathrm{L} \\
\text { 0xides } \\
\end{array}$ & wtw & $\begin{array}{c}\mathrm{g} / \mathrm{L} \\
\text { 0xides } \\
\end{array}$ & -4 & $\begin{array}{c}/ L \\
\text { 0xides }\end{array}$ & wt. & $\begin{array}{c}\mathrm{g} / \mathrm{L} \\
0 \times 1 \text { des } \\
\end{array}$ & wtz & $\begin{array}{c}\mathrm{g} / \mathrm{L} \\
\text { 0xides }\end{array}$ & 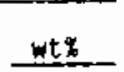 & $\begin{array}{c}/ L \\
0 x i d e s \\
\end{array}$ & wtx & $\begin{array}{r}9 /[ \\
0 x i d e s \\
\end{array}$ & $w t x$ & $\begin{array}{c}9 / \mathrm{L} \\
0 x i \text { des } \\
\end{array}$ & $\mathrm{Ht} \%$ \\
\hline $\mathrm{Al}_{2} \mathrm{O}_{3}$ & 17.80 & 4.24 & 17.70 & 4.22 & 17.40 & 4.17 & 17.80 & 4.20 & 17.80 & 4.19 & 16.60 & 3.89 & 16.60 & 4.01 & 17.2 & 4.30 \\
\hline $\mathrm{B}_{2} \mathrm{O}_{3}$ & 36.70 & 8.74 & 37.00 & 8.82 & 36.20 & 8.67 & 37.20 & 8.78 & 37.10 & 8.74 & 37.10 & 8.69 & 36.10 & 8.72 & 38.2 & 9.56 \\
\hline $\mathrm{BaO}$ & 1.14 & 0.27 & 1.13 & 0.27 & 1.15 & 0.28 & 1.16 & 0.27 & 1.15 & 0.27 & 1.15 & 0.27 & 1.07 & 0.26 & 0.40 & 0.10 \\
\hline $\mathrm{CaO}$ & 10.80 & 2.57 & 10.90 & 2.60 & 10.80 & 2.59 & 10.80 & 2.55 & 11.00 & 2.59 & 11.30 & 2.65 & 11.30 & 2.73 & 11.5 & 2.89 \\
\hline $\mathrm{CeO}_{2}$ & 0.56 & 0.13 & 0.65 & 0.15 & 0.59 & 0.14 & 0.61 & 0.14 & 0.59 & 0.14 & 0.39 & 0.09 & 0.70 & 0.17 & 0.7 & 0.18 \\
\hline $\mathrm{Cr}_{2} \mathrm{O}_{3}$ & 5.07 & 1.21 & 4.91 & 1.17 & 5.11 & 1.22 & 5.04 & 1.19 & 5.15 & 1.21 & 5.13 & 1.20 & 4.90 & 1.18 & 5.3. & 1.33 \\
\hline $\mathrm{Cs}_{2} \mathrm{O}$ & 1.30 & 0.31 & 1.30 & 0.31 & 1.40 & 0.34 & 1.40 & 0.33 & 1.70 & 0.40 & 1.40 & 0.33 & 1.32 & 0.32 & 1.0 & 0.25 \\
\hline $\mathrm{CuO}$ & 0.65 & 0.15 & 0.63 & 0.15 & 0.64 & 0.15 & 0.64 & 0.15 & 0.64 & 0.15 & 0.64 & 0.15 & 0.44 & 0.11 & 0.6 & 0.15 \\
\hline$F(a)$ & 1.20 & 0.29 & 1.20 & 0.29 & 1.20 & 0.29 & 1.20 & 0.28 & 1.20 & 0.28 & 1.20 & 0.28 & 1.20 & 0.29 & 1.2 & 0.30 \\
\hline $\mathrm{Fe}_{2} \mathrm{O}_{3}$ & 44.50 & 10.59 & 43.50 & 10.37 & 44.60 & 10.68 & 44.60 & 10.53 & 44.50 & 10.49 & 44.80 & 10.49 & 44.50 & 10.75 & 44.4 & 11.10 \\
\hline $\mathrm{La}_{2} \mathrm{O}_{3}$ & 2.09 & 0.50 & 2.16 & 0.51 & 2.03 & 0.49 & 2.12 & 0.50 & 2.12 & 0.50 & 2.13 & 0.50 & 1.90 & 0.46 & 2.2 & 0.55 \\
\hline $\operatorname{Li}_{2} 0$ & 14.30 & 3.40 & 14.40 & 3.43 & 14.10 & 3.38 & 14.50 & 3.42 & 14.60 & 3.44 & 14.50 & 3,40 & 13.30 & 3.21 & 15.0 & 3.75 \\
\hline $\mathrm{MgO}$ & 3.39 & 0.81 & 3.51 & 0.84 & 3.42 & 0.82 & 3.41 & 0.81 & 3.45 & 0.81 & 3.48 & 0.81 & 2.04 & 0.49 & 3.3 & 0.83 \\
\hline $\mathrm{MnO}_{2}$ & 0.80 & 0.19 & 0.79 & 0.19 & 0.80 & 0.19 & 0.81 & 0.19 & 0.79 & 0.19 & 0.81 & 0.19 & 0.76 & 0.18 & 0.7 & 0.18 \\
\hline $\mathrm{MoO}_{3}$ & 1.42 & 0.34 & 1,40 & 0.33 & 1.41 & 0.34 & 1.40 & 0.33 & 1.43 & 0.34 & 1.42 & 0.33 & 0.75 & 0.18 & 1.2 & 0.30 \\
\hline $\mathrm{Na}_{2} \mathrm{O}$ & 43.00 & 10.24 & 43.30 & 10.32 & 43.40 & 10.39 & 43.40 & 10.25 & 43.80 & 10.32 & 44.60 & 10.44 & 49.10 & 11.86 & 41.5 & 10.37 \\
\hline $\mathrm{Nd}_{2} \mathrm{O}_{3}$ & 1.92 & 0.46 & 1.91 & 0.46 & 1.96 & 0.47 & 1.94 & 0.46 & 1.96 & 0.46 & 1.93 & 0.45 & 0.93 & 0.22 & 2.1 & 0.53 \\
\hline $\mathrm{NiO}$ & 2.26 & 0.54 & 2.18 & 0.52 & 2.23 & 0.53 & 2.25 & 0.53 & 2.25 & 0.53 & 2,16 & 0.51 & 1.91 & 0.46 & 2.4 & 0.60 \\
\hline $\mathrm{SiO}_{2}$ & 225.00 & 53.57 & 225.00 & 53.62 & 223.00 & 53.40 & 227.00 & 53.60 & 227.00 & 53.49 & 230.00 & 53.86 & 219.00 & 52.92 & 204.8 & 51.19 \\
\hline $\mathrm{SO}_{3}(\mathrm{a})$ & 1.50 & 0.36 & 1.50 & 0.36 & 1.50 & 0.36 & 1.50 & 0.35 & 1.50 & 0.35 & 1.50 & 0.35 & 1.50 & 0.36 & 1.5 & 0.38 \\
\hline Sro & 0.39 & 0.09 & 0.37 & 0.09 & 0.39 & 0.09 & 0.38 & 0.09 & 0.38 & 0.09 & 0.38 & 0.09 & 0.36 & 0.09 & 0.4 & 0.10 \\
\hline $\mathrm{TiO}_{3}$ & 1.17 & 0.28 & 1.15 & 0.27 & 1.17 & 0.28 & 1.17 & 0.28 & 1.17 & 0.28 & 1.18 & 0.28 & 1.13 & 0.27 & 0.0 & 0.00 \\
\hline $\operatorname{Toc}(a)$ & 0.60 & 0.14 & 0.60 & 0.14 & 0.60 & 0.14 & 0.60 & 0.14 & 0.60 & 0.14 & 0.60 & 0.14 & 0.60 & 0.14 & 0.6 & 0.15 \\
\hline $\mathrm{ZrO}_{2}$ & 2.47 & 0.59 & 2.42 & 0.58 & 2.53 & 0.61 & 2.55 & 0.60 & 2.49 & 0.59 & 2.65 & 0.62 & 2.45 & 0.59 & 2.4 & 0.60 \\
\hline TOTAL & 420.03 & 100.00 & 419.61 & 100.00 & 417.62 & 100.00 & 423.48 & 100.00 & 424.37 & 100.00 & 427.05 & 100.00 & 413.86 & 100.00 & 398.6 & 99.69 \\
\hline$\rho H$ & 10.50 & & 10.60 & & 10.50 & & 10.50 & & 10.60 & & 10.60 & & 10.60 & & & \\
\hline
\end{tabular}

(a) Not analyzed for, assumed Target Value. 
TABLE A.6. Normalized Compositions of Glass Samples Taken During L.FMM-86-2 (Analysis Performed by ICP)

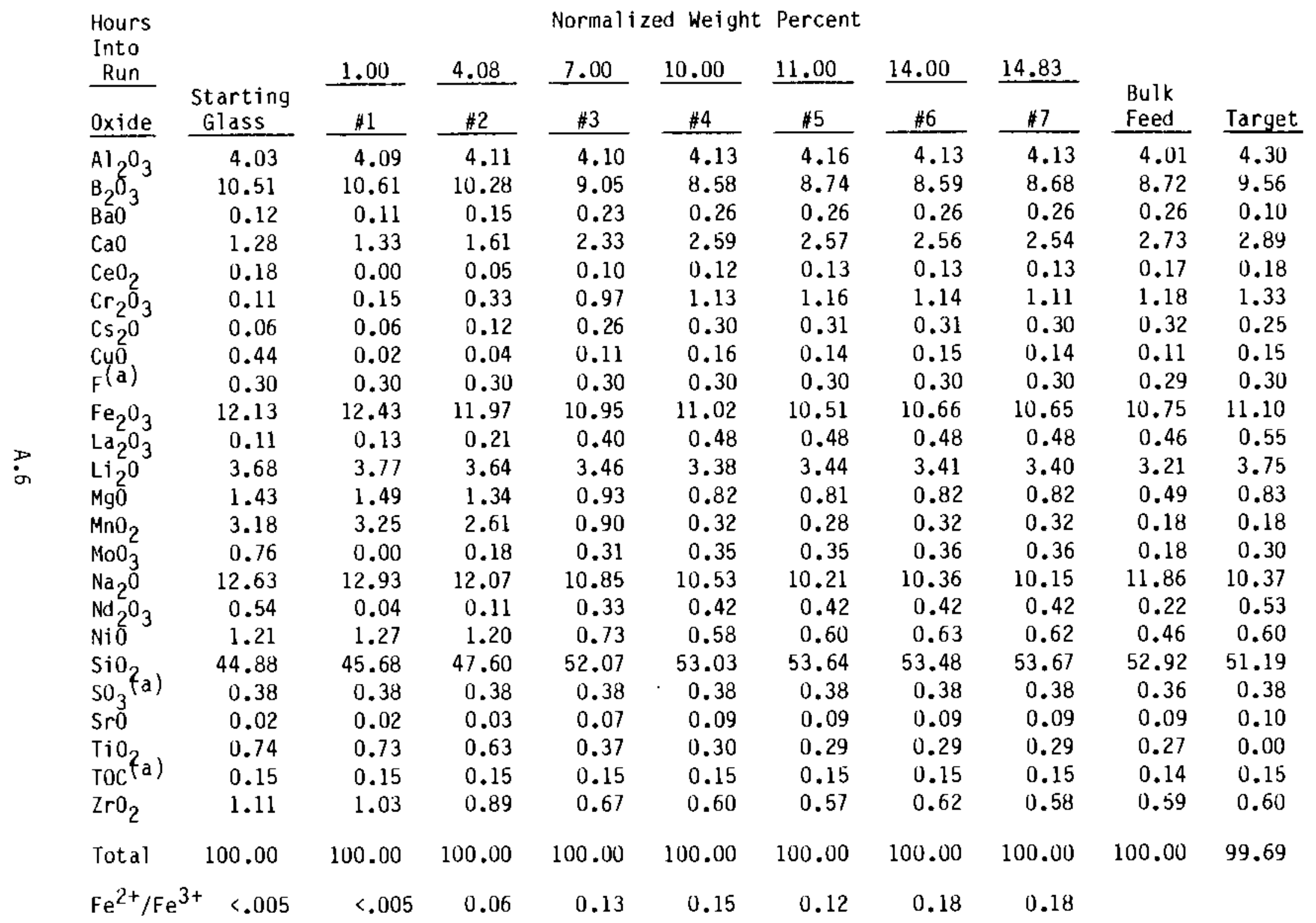

(a) Not analyzed for assumed, target level. 
TABLE A.7. Composition of HWVP Simulated Melter Feed Used in LFMM-B6-3

\begin{tabular}{|c|c|c|c|c|}
\hline Compound (a) & $\begin{array}{r}\text { Total ox } \\
\text { Waste Lo } \\
\text { Waste } U x \\
\text { Compound } \\
\text { Concentration, } g / L \\
\end{array}$ & $\begin{array}{l}(g / L) \\
\lg (x) \\
5(g / L) \\
\text { oxide } \\
\end{array}$ & $\begin{array}{r}400 \\
25 \\
100 \\
\quad \text { oxide } \\
\text { Concentration, } g / L\end{array}$ & Glass wt: \\
\hline $\begin{array}{l}\mathrm{Al}(\mathrm{OH})_{3} \\
\mathrm{BaSO}_{4} \\
\mathrm{CaF}_{2} \\
\mathrm{Ce}(\mathrm{OH})_{3}\end{array}$ & $\begin{array}{r}26.62 \\
0.61 \\
0.45 \\
0.80\end{array}$ & $\begin{array}{l}\mathrm{Al}_{2} \mathrm{O}_{3} \\
\mathrm{BaO} \\
\mathrm{CaO} \\
\mathrm{CeO}_{2}\end{array}$ & $\begin{array}{r}17.40 \\
0.40 \\
0.32 \\
0.72\end{array}$ & $\begin{array}{l}4.35 \\
0.10 \\
0.08 \\
0.18\end{array}$ \\
\hline & $\begin{array}{l}7.32 \\
1.45\end{array}$ & $\begin{array}{l}\mathrm{Cr}_{2} \mathrm{O}_{3} \\
\mathrm{CsO}_{2}\end{array}$ & $\begin{array}{l}5.40 \\
1.00\end{array}$ & 1.35 \\
\hline $\begin{array}{l}\mathrm{Cu}(\mathrm{OH})_{2} \\
\mathrm{Fe}(\mathrm{OH})_{3} \\
\mathrm{Mg}(\mathrm{OH})_{2}\end{array}$ & $\begin{array}{r}0.74 \\
60.06 \\
0.46\end{array}$ & $\begin{array}{l}\mathrm{CuO} \\
\mathrm{Fe}_{2} \mathrm{O}_{3} \\
\mathrm{MgO}\end{array}$ & $\begin{array}{r}0.60 \\
44.88 \\
0.32\end{array}$ & $\begin{array}{r}0.15 \\
11.22 \\
0.08\end{array}$ \\
\hline $\begin{array}{l}\mathrm{Mn}(\mathrm{OH})_{2}^{2} \\
\mathrm{Na}_{2} \mathrm{MOO}_{4}^{2} \cdot 2 \mathrm{H}_{2} \mathrm{O} \\
\mathrm{Ni}(\mathrm{OH})_{2} \\
\mathrm{Pr}(\mathrm{OH})_{3} \\
\mathrm{SiO}_{2}\end{array}$ & $\begin{array}{l}0.74 \\
2.02 \\
2.98 \\
0.45 \\
3.08\end{array}$ & $\begin{array}{l}\mathrm{MnO}_{2} \\
\mathrm{MoO}_{3} \\
\mathrm{NiO} \\
\mathrm{Pr}_{6} \mathrm{O}_{11} \\
\mathrm{SiO}_{2}\end{array}$ & $\begin{array}{l}0.72 \\
1.20 \\
2.40 \\
0.40 \\
3.08\end{array}$ & $\begin{array}{l}0.18 \\
0.30 \\
0.60 \\
0.10 \\
0.77\end{array}$ \\
\hline $\begin{array}{l}\mathrm{Sm}(\mathrm{OH})_{3} \\
\mathrm{Sr}(\mathrm{OH})_{2} \cdot 8 \mathrm{H}_{2} \mathrm{O}\end{array}$ & $\begin{array}{l}0.23 \\
1.02\end{array}$ & $\begin{array}{l}\mathrm{Sm}_{2} \mathrm{O}_{3} \\
\mathrm{SrO}\end{array}$ & $\begin{array}{l}0.20 \\
0.40\end{array}$ & $\begin{array}{l}0.05 \\
0.10\end{array}$ \\
\hline $\begin{array}{l}\mathrm{Y}(\mathrm{OH})_{3} \\
\mathrm{Zr}(\mathrm{OH})_{4} \cdot 5 \mathrm{H}_{2} \mathrm{O}\end{array}$ & $\begin{array}{l}0.25 \\
4.94\end{array}$ & $\begin{array}{l}\mathrm{Y}_{2} \mathrm{O}_{3} \\
\mathrm{ZrO}_{2}\end{array}$ & $\begin{array}{l}0.20 \\
2.44\end{array}$ & $\begin{array}{l}0.05 \\
0.61\end{array}$ \\
\hline $\begin{array}{l}\mathrm{La}(\mathrm{OH})_{3} \\
\mathrm{LaF}_{3}\end{array}$ & $\begin{array}{l}0.47 \\
2.16\end{array}$ & $\mathrm{La}_{2} \mathrm{O}_{3}$ & 2.20 & 0.55 \\
\hline $\begin{array}{l}\mathrm{NaOH} \\
\mathrm{NaNO}_{3} \\
\mathrm{Na}_{2} \mathrm{C}_{2} \mathrm{O}_{4}\end{array}$ & $\begin{array}{r}3.26 \\
13.60 \\
3.42\end{array}$ & $\mathrm{Na}_{2} \mathrm{O}$ & 10.88 & 2.72 \\
\hline $\begin{array}{l}\mathrm{Nd}(\mathrm{OH})_{3} \\
\mathrm{NdF}_{3}\end{array}$ & $\begin{array}{l}1.84 \\
0.64\end{array}$ & $\mathrm{Nd}_{2} \mathrm{O}_{3}$ & 2.12 & 0.53 \\
\hline $\mathrm{NaF}$ & 0.22 & $F=$ & 1.20 & 0.30 \\
\hline \multirow[t]{3}{*}{$\begin{array}{l}\mathrm{Na}_{2} \mathrm{SO}_{4} \\
\text { Subtotals }\end{array}$} & $\begin{array}{r}2.33 \\
142.16\end{array}$ & $\mathrm{SO}_{3}$ & $\begin{array}{r}1.52 \\
100.00\end{array}$ & $\begin{array}{r}0.38 \\
25.00\end{array}$ \\
\hline & $\begin{array}{l}\text { HW-39 Frit } \\
\text { Subtotals }\end{array}$ & $\begin{array}{l}\mathrm{SiO}_{2} \\
\mathrm{~B}_{2} \mathrm{O}_{3} \\
\mathrm{Na}_{2} \\
\mathrm{Li}^{0} \\
\mathrm{CaO}^{0} \\
\mathrm{MgO}\end{array}$ & $\begin{array}{r}201.76 \\
38.24 \\
30.76 \\
15.00 \\
11.24 \\
\frac{3.00}{300.00} \mathrm{~g} / \mathrm{L}\end{array}$ & $\begin{array}{l}50.44 \\
9.56 \\
7.69 \\
3.75 \\
2.81 \\
0.75 \\
75.0 \mathrm{wt} \%\end{array}$ \\
\hline & Totals & & $400.00 \mathrm{~g} / \mathrm{L}$ & $100.00 \mathrm{wt} \%$ \\
\hline
\end{tabular}

(a) Prior to reaction with formic acid. 
IABLE A.8. Feed Sample Compositions Taken During LFMM-86-3

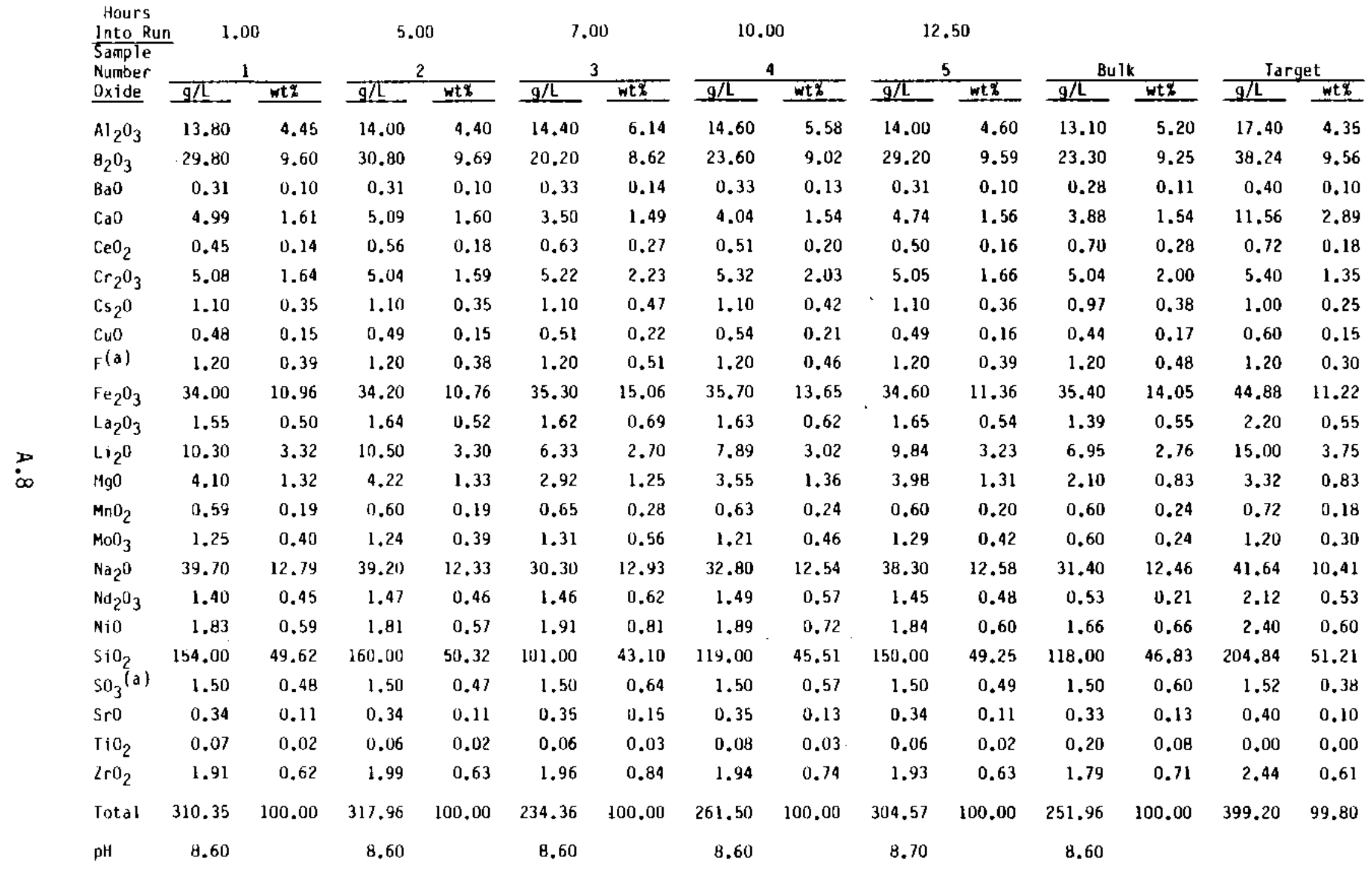

(a) Not analyzed for, assumed target value. 
TABLE A.9. Normalized Composition of Glass Samples Taken During LFMM-86-3

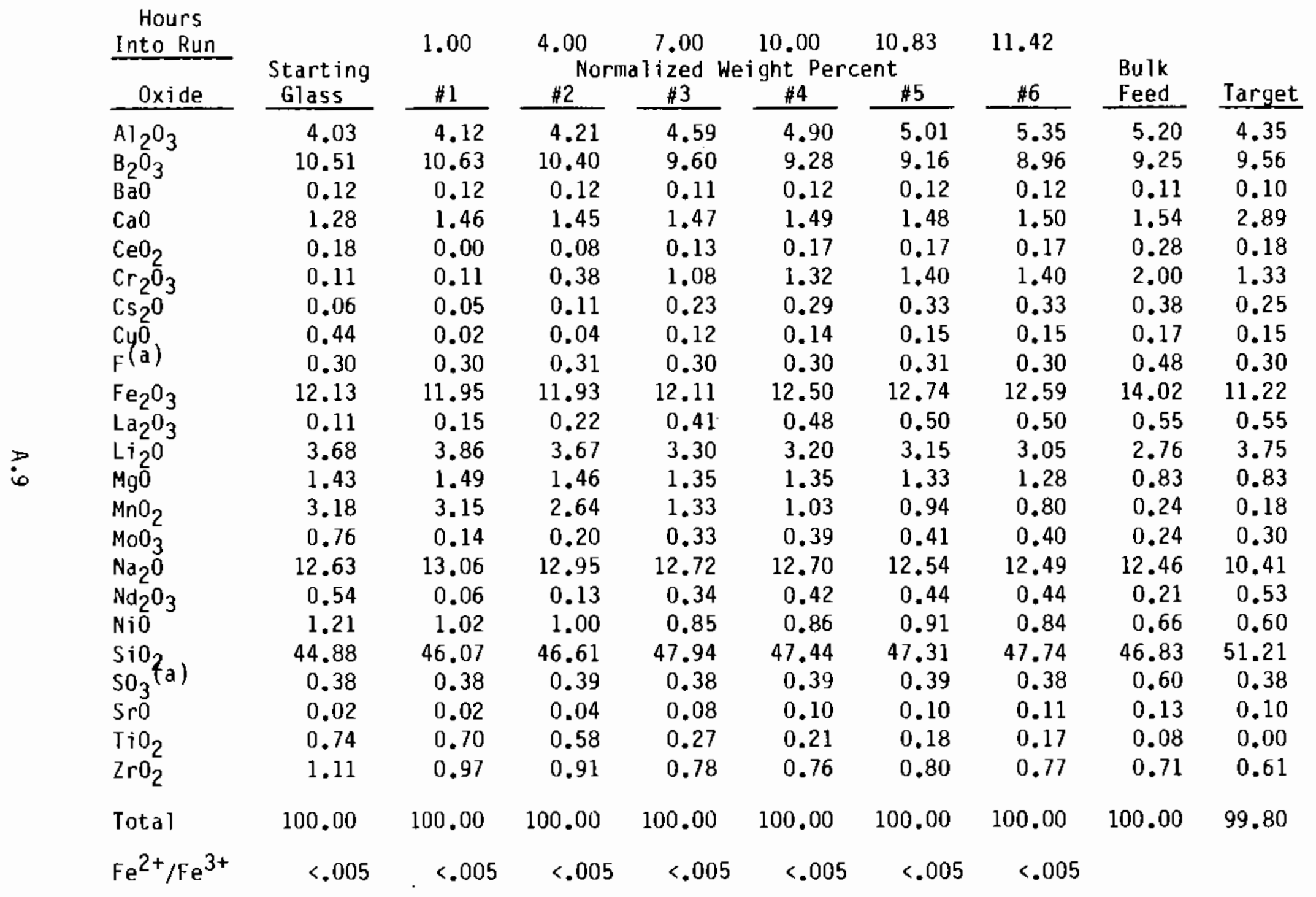

(a) Not analyzed for, assumed target value. 
TABLE A.10. FRG 8 Feed Composition Used in LFMM-86-4

\begin{tabular}{|c|c|c|c|c|}
\hline Compound & $\begin{array}{c}\text { Concentration, } \\
\mathrm{g} / \mathrm{L}\end{array}$ & $\begin{array}{c}\text { Assumed } \\
\text { Oxide } \\
\end{array}$ & $\begin{array}{c}\text { Concentration, } \\
\mathrm{g} / \mathrm{L}\end{array}$ & Glass wt: \\
\hline $\mathrm{Al}\left(\mathrm{NO}_{3}\right)_{2} \cdot 9 \mathrm{H}_{2} \mathrm{O}$ & 100.84 & $\mathrm{Al}_{2} \mathrm{O}_{3}$ & 8.40 & 2.40 \\
\hline $\mathrm{Na}_{2} \mathrm{~B}_{4} \mathrm{O}_{7} \cdot 10 \mathrm{H}_{2} \mathrm{O}$ & 143.74 & $\mathrm{~B}_{2} \mathrm{O}_{3}$ & 52.50 & 15.00 \\
\hline $\mathrm{Ba}\left(\mathrm{NO}_{3}^{+}\right)_{2}$ & 7.76 & $\mathrm{BaO}$ & 4.55 & 1.30 \\
\hline $\mathrm{Ca}\left(\mathrm{NO}_{3}\right)_{2}$ & 9.10 & $\mathrm{CaO}$ & 2.84 & 0.81 \\
\hline $\mathrm{Ce}\left(\mathrm{NO}_{3}\right)_{3} \cdot 9 \mathrm{H}_{2} \mathrm{O}$ & 2.88 & $\mathrm{CeO}_{2}$ & 1.02 & 0.29 \\
\hline $\mathrm{Cr}\left(\mathrm{NO}_{3}\right)_{3} \cdot 9 \mathrm{H}_{2} \mathrm{O}$ & 12.90 & $\mathrm{Cr}_{2} \mathrm{O}_{3}$ & 2.45 & 0.70 \\
\hline $\mathrm{CsNO}_{3}$ & 27.98 & $\mathrm{Cs}{ }^{2} \mathrm{O}^{\circ}$ & 20.23 & 5.78 \\
\hline $\mathrm{Fe}\left(\mathrm{NO}_{3}\right)_{3} \cdot 9 \mathrm{H}_{2} \mathrm{O}$ & 178.65 & $\mathrm{Fe}_{2} \mathrm{O}_{3}$ & 35.32 & 10.09 \\
\hline $\mathrm{La}\left(\mathrm{NO}_{3}\right)_{3} \cdot 6 \mathrm{H}_{2} \mathrm{O}$ & 11.08 & $\mathrm{La}_{2} \mathrm{O}_{3}$ & 4.20 & 1.20 \\
\hline $\mathrm{Mg}\left(\mathrm{NO}_{3}\right)_{2} \cdot 6 \mathrm{H}_{2} \mathrm{O}$ & 11.80 & $\mathrm{MgO}$ & 1.86 & 0.53 \\
\hline $\operatorname{Mn}\left(\mathrm{NO}_{3}\right)_{2} \cdot 4 \mathrm{H}_{2} \mathrm{O}$ & 12.64 & $\mathrm{MnO}_{2}$ & 2.70 & 0.77 \\
\hline $\mathrm{NaNO}_{3}$ & 51.10 & $\mathrm{Na}_{2} \mathrm{O}$ & 42.00 & 12.00 \\
\hline $\mathrm{Nd}_{2} \mathrm{O}_{3}$ & 3.85 & $\mathrm{Nd}_{2} \mathrm{O}_{3}$ & 3.85 & 1.10 \\
\hline $\mathrm{Ni}\left(\mathrm{NO}_{3}\right)_{2} \cdot 6 \mathrm{H}_{2} \mathrm{O}$ & 4.09 & $\mathrm{NiO}$ & 1.05 & 0.30 \\
\hline Pbo 32 & 2.42 & Pbo & 2.42 & 0.69 \\
\hline $\mathrm{SiO}_{2}$ & 157.50 & $\mathrm{SiO}_{2}$ & 157.50 & 45.00 \\
\hline $\mathrm{Sr}\left(\mathrm{NO}_{3}\right)_{2}$ & 13.72 & $\mathrm{SrO}^{2}$ & 6.72 & 1.92 \\
\hline Zno & 0.18 & $\operatorname{Zno}$ & 0.18 & 0.05 \\
\hline $\mathrm{ZrO}\left(\mathrm{NO}_{3}\right)_{2} \cdot 2 \mathrm{H}_{2} \mathrm{O}$ & 0.53 & $\mathrm{ZrO}_{2}$ & 0.24 & 0.07 \\
\hline Total & 752.76 & & 350.03 & 100.00 \\
\hline
\end{tabular}


TABLE A.11. ICP Analyses of Feed Samples Taken During LFMM-86-4

Hours

Into Ru

Number

Oxide

$\mathrm{Al}_{2} \mathrm{O}_{3}$
$\mathrm{~B}_{2} \mathrm{O}_{3}$

9

3.00

8.40

$\mathrm{BaO}$

$\mathrm{CaO}$

$\mathrm{CeO}_{2}$

$\mathrm{Cr}_{2} \mathrm{O}_{3}$

$\mathrm{Cs}_{2} \mathrm{O}$

$\mathrm{Fe}_{2} \mathrm{O}_{3} \quad 36.70$

1

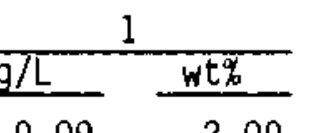

$\frac{2}{9 / \mathrm{L}} \frac{\mathrm{wt} \%}{2.11}$

$\frac{\text { Bulk Feed }}{\frac{\mathrm{g} / \mathrm{L}}{8.76}} \frac{\mathrm{wt} \%}{2.26}$

$\frac{\text { Target }}{8 / L} \frac{w t \%}{2.40}$

$71.80 \quad 16.53$

$76.50 \quad 17.23$

$$
69.90
$$

18.04

52.50

2.40

$4.87 \quad 1.10$

4.55

1.17

2.89

0.65

2.73

0.70

4.55

2.84

1.30

$2.83 \quad 0.65$

1.29

0.29

1.22

0.31

1.02

0.81

$2.62 \quad 0.60$

2.70

0.61

2.54

0.66

2.45

5.94

20.23

9.19

35.32

1.08

4.20

0.55

1.86

2.70

0.82

42.00

3.85

1.02

1.05

0.29

0.70

$\mathrm{MgO}$

3.32

0.76

3.39
55.00

0.76
12.39

53.50

4.25

0.96

3.97

0.27

2.42

0.00

0.00

0.00

0.00

42.33

157.50

1.70

6.7

1.59

164.00

6.58

0.05

0.18

0.08

0.24

5.78

10.09

1.20

0.53

0.77

7.05
0.21

0.05
0.09

0.31

12.00

1.10

0.30

0.39

100.00

387.40

100.00

350.03

100.00 
TABLE A.12. ICP Analyses of Glass Samples Taken During LFMM-86-4

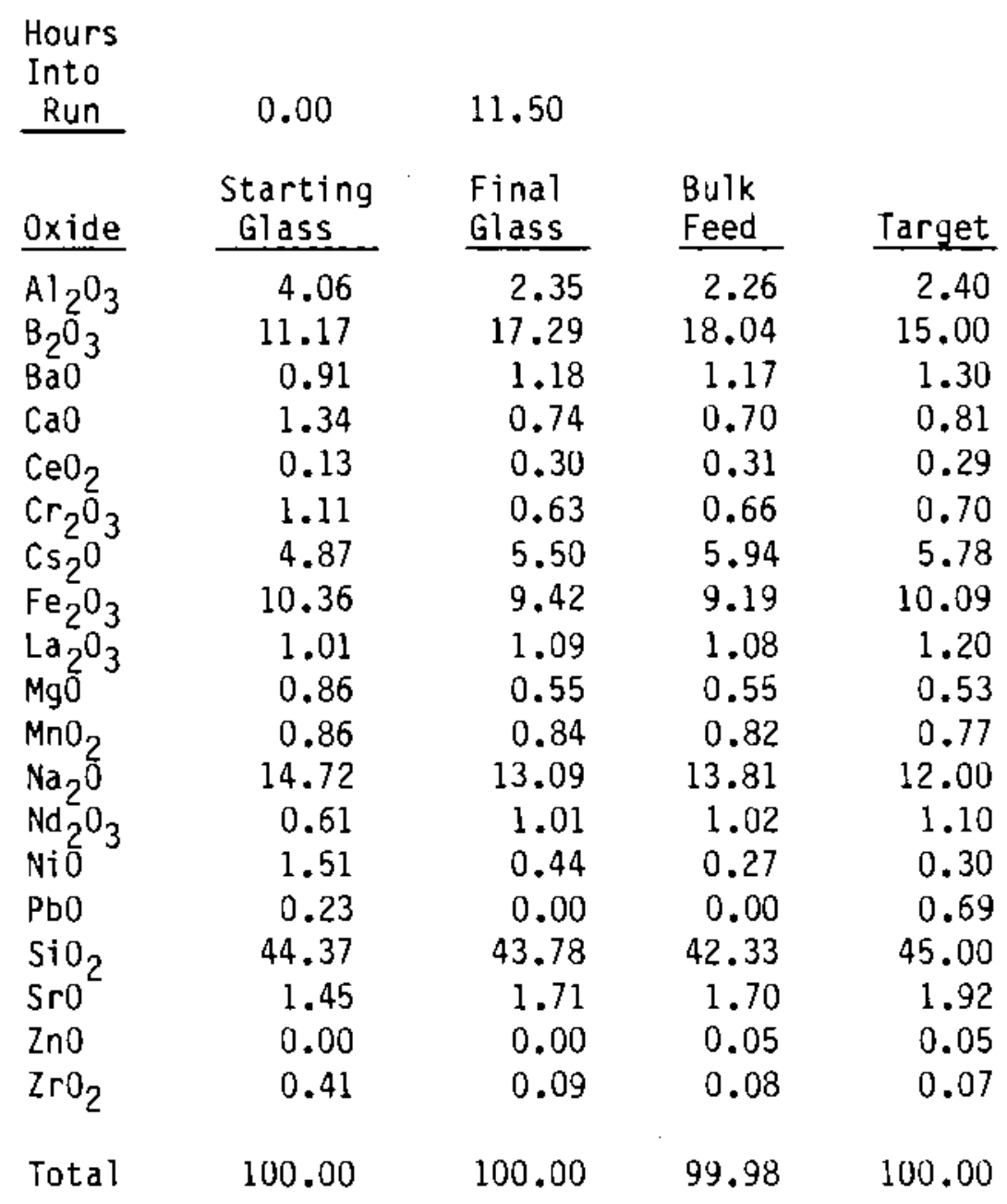


TABLE A.13. Simulated West Valley Melter Feed, Composition (WV182) Used in LFMM-86-5 and LFMM-86-6 (a)

\begin{tabular}{|c|c|c|c|c|c|c|c|c|}
\hline$\frac{\text { Substituted Waste }}{\text { Compound }}$ & $g / L$ & $\begin{array}{l}\text { Assumed } \\
\text { Oxide } \\
\text { Compound }\end{array}$ & $g / L$ & $\begin{array}{l}\text { Final } \\
\text { Glass } \\
\text { Oxide } \\
\end{array}$ & $g / L$ & wt\% & $\begin{array}{r}\text { Norma } 1 \\
\text { Analys is } 0 \\
\text { LFMM-86-5 }\end{array}$ & $\begin{array}{l}\text { ed ICP } \\
\text { Feed wt\% } \\
\text { LFMM-86-6 } \\
\end{array}$ \\
\hline $\begin{array}{l}\mathrm{Fe}\left(\mathrm{NO}_{3}\right)_{3} \cdot 9 \mathrm{H}_{2} \mathrm{O} \\
\mathrm{NaNO} \mathrm{O}_{3} \\
\mathrm{Al}\left(\mathrm{NO}_{3}\right)_{3} \cdot 9 \mathrm{H}_{2} \mathrm{O} \\
\mathrm{Cr}\left(\mathrm{NO}_{3}\right)_{3} \cdot 6 \mathrm{H}_{2} \mathrm{O} \\
\mathrm{Ni}\left(\mathrm{NO}_{3}\right)_{2} \cdot 6 \mathrm{H}_{2} \mathrm{O} \\
\mathrm{Ce}\left(\mathrm{NO}_{3}\right)_{3} \cdot 9 \mathrm{H}_{2} \mathrm{O} \\
\mathrm{Rare} \text { Earth } \\
\mathrm{KNO} \\
\mathrm{CsNO} \\
\mathrm{Mn}\left(\mathrm{NO}_{3}\right)_{2} \cdot 4 \mathrm{H}_{2} \mathrm{O} \\
\mathrm{ZrO}\left(\mathrm{NO}_{3}\right)_{2} \cdot 2 \mathrm{H}_{2} \mathrm{O} \\
\mathrm{NaCl} \\
\mathrm{Ba}\left(\mathrm{NO}_{3}\right)_{2} \\
\mathrm{FePO}{ }_{4} \mathrm{H}_{2} \mathrm{O} \\
\mathrm{Na}_{2} \mathrm{SO}_{4} \\
\mathrm{RuO} \\
\mathrm{Y}_{2} \mathrm{O}_{3} \\
\mathrm{Sr}\left(\mathrm{NO}_{3}\right)_{2}\end{array}$ & $\begin{array}{c}158.0 \\
8.9 \\
14.7 \\
12.5 \\
6.1 \\
14.6 \\
1.7 \\
0.60 \\
0.48 \\
4.9 \\
14.7 \\
0.34 \\
0.36 \\
24.1 \\
0.87 \\
0.28 \\
0.07 \\
0.22 \\
263.4\end{array}$ & 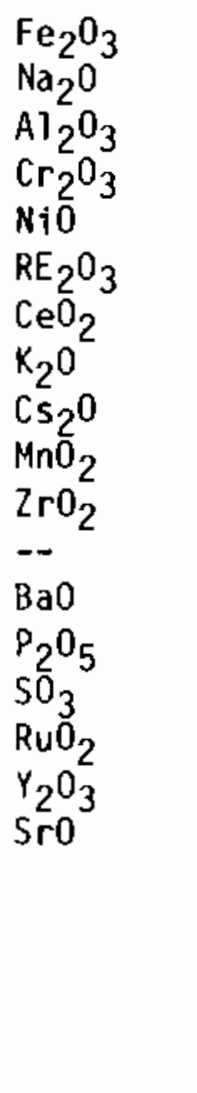 & $\begin{array}{r}41.51 \\
3.64 \\
2.00 \\
2.38 \\
1.58 \\
10.26 \\
0.60 \\
0.28 \\
0.35 \\
1.68 \\
5.88 \\
-- \\
0.21 \\
9.14 \\
0.49 \\
0.28 \\
0.07 \\
0.11 \\
80.5\end{array}$ & 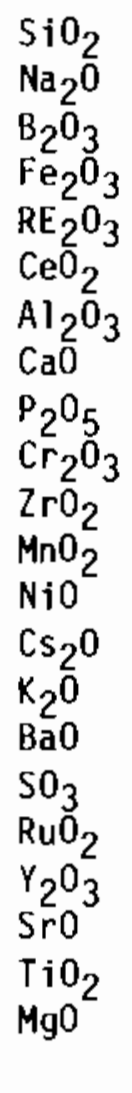 & $\begin{array}{r}156.4 \\
52.8 \\
44.4 \\
43.0 \\
10.2 \\
0.6 \\
8.4 \\
10.5 \\
9.1 \\
2.38 \\
5.88 \\
1.72 \\
1.58 \\
0.35 \\
0.60 \\
0.35 \\
0.70 \\
0.28 \\
0.07 \\
0.10 \\
0.10 \\
0.35 \\
349.9\end{array}$ & $\begin{array}{c}44.7 \\
15.1 \\
12.7 \\
12.3 \\
2.9 \\
0.17 \\
2.4 \\
3.0 \\
2.6 \\
0.68 \\
1.68 \\
0.49 \\
0.45 \\
0.10 \\
0.17 \\
0.10 \\
0.20 \\
0.08 \\
0.02 \\
0.03 \\
0.03 \\
0.10 \\
100.0\end{array}$ & $\begin{array}{c}45.00 \\
14.86 \\
13.09 \\
11.79 \\
0.06 \\
1.75 \\
2.58 \\
2.48 \\
2.51 \\
0.68 \\
1.06 \\
2.80 \\
0.45 \\
0.08 \\
0.17(b) \\
0.08 \\
0.20(b) \\
0.08 \text { (b) } \\
0.02(b) \\
0.06 \\
0.04 \\
0.17 \\
100.00\end{array}$ & $\begin{array}{c}44.37 \\
14.57 \\
13.18 \\
11.48 \\
0.07 \\
1.72 \\
2.49 \\
2.44 \\
2.58 \\
0.66 \\
2.33 \\
2.73 \\
0.43 \\
0.07 \\
0.19(\mathrm{~b}) \\
0.07 \\
0.22(\mathrm{~b}) \\
0.09 \text { (b) } \\
0.02 \\
0.06 \\
0.04 \\
0.19 \\
100.00\end{array}$ \\
\hline
\end{tabular}

(a) LFMM-86-5 feed contains no sugar, LFMM-86-6 feed contains $75 \mathrm{~g} / \mathrm{L}$ sugar.

(b) Not analyzed for, assumed target levels prior to normalization. 
TABLE A.13. (contd)

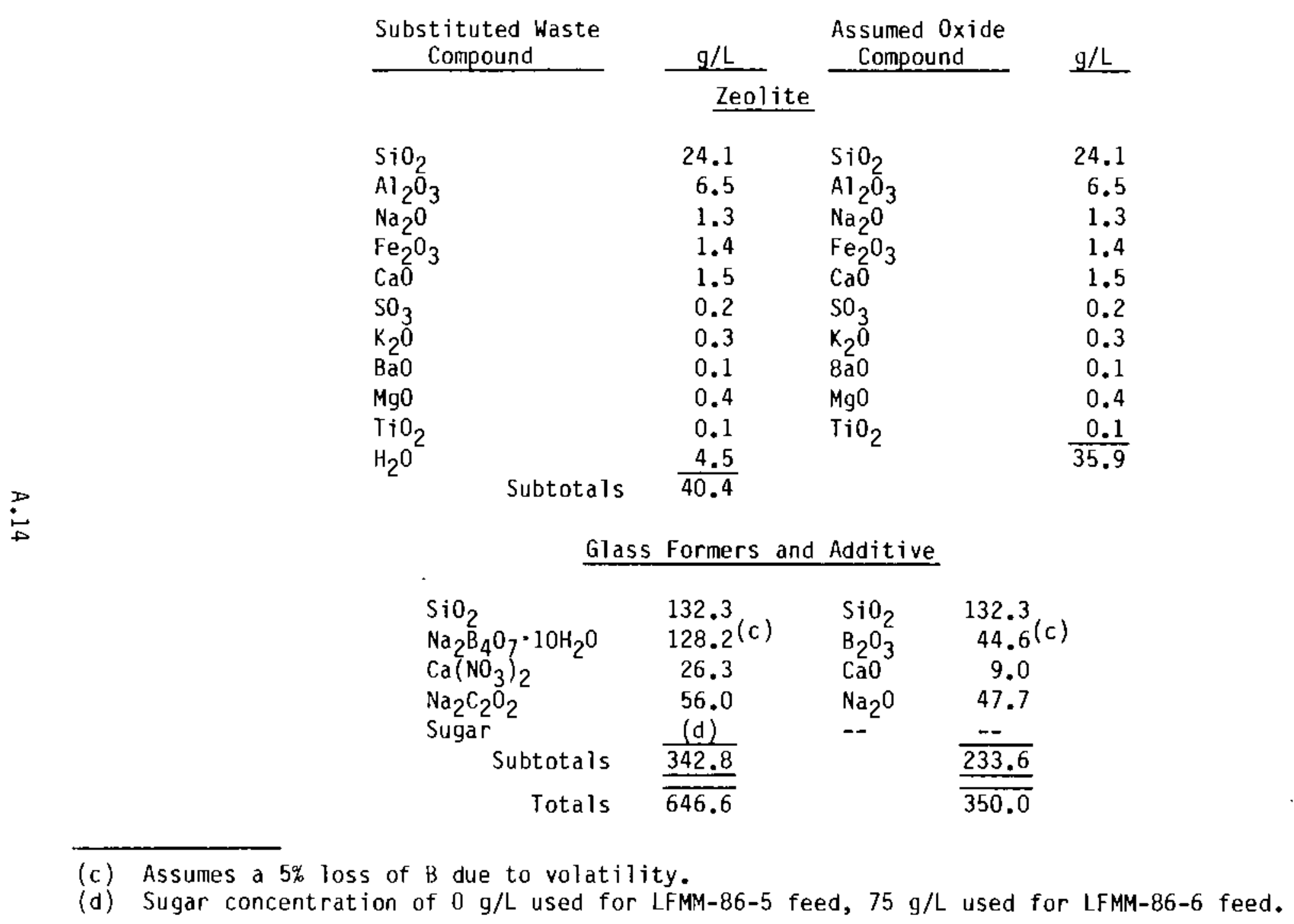


TABLE A.14. ICP Analyses of Feed Samples Taken During LFMM-86-5

\begin{tabular}{|c|c|c|c|c|c|c|c|c|c|c|}
\hline $\begin{array}{l}\text { Hours } \\
\text { Into } \\
\text { Run } \\
\text { Sample }\end{array}$ & $\begin{array}{r}1 . \\
\text { Lunadju }\end{array}$ & ed) (b) & (adjus & $\begin{array}{l}00 \\
\mathrm{ed})\end{array}$ & & & Bulk & Feed & & get \\
\hline $\begin{array}{l}\text { Number } \\
\text { Oxide }\end{array}$ & $\begin{array}{c}\mathrm{g} / \mathrm{L} \\
\text { 0xides }\end{array}$ & wt\% & $\begin{array}{c}/ L \\
0 x i d e s \\
\end{array}$ & wt\% & $\begin{array}{c}\mathrm{g} / \mathrm{L} \\
\text { oxides } \\
\end{array}$ & wt\% & $\begin{array}{c}\mathrm{g} / \mathrm{L} \\
\text { 0xides } \\
\end{array}$ & $w t \%$ & $\begin{array}{c}\mathrm{g} / \mathrm{L} \\
0 \times \mathrm{dides} \\
\end{array}$ & wt\% \\
\hline $\mathrm{Al}_{2} \mathrm{O}_{3}$ & 10.30 & 2.62 & 9.55 & 2.60 & 10.10 & 2.61 & 8.89 & 2.58 & 8.40 & 2.40 \\
\hline $\mathrm{B}_{2} \mathrm{O}_{3}$ & 50.00 & 12.74 & 48.80 & 13.27 & 53.20 & 13.74 & 45.10 & 13.09 & 44.40 & 12.70 \\
\hline $80^{3}$ & 0.30 & 0.08 & 0.28 & 0.08 & 0.29 & 0.07 & 0.26 & 0.08 & 0.35 & 0.10 \\
\hline $\mathrm{CaO}$ & 10.40 & 2.65 & 9.39 & 2.55 & 9.81 & 2.53 & 8.54 & 2.48 & 10.50 & 3.00 \\
\hline $\mathrm{CeO}_{2}$ & 7.04 & 1.79 & 6.60 & 1.79 & 6.76 & 1.75 & 6.03 & 1.75 & 0.60 & 0.17 \\
\hline $\mathrm{Cr}_{2} \mathrm{O}_{3}$ & 2.74 & 0.70 & 2.51 & 0.68 & 2.65 & 0.68 & 2.33 & 0.68 & 2.38 & 0.68 \\
\hline $\mathrm{Cs}_{2} \mathrm{O}^{\mathrm{O}}$ & 0.27 & 0.07 & 0.26 & 0.07 & 0.29 & 0.07 & 0.27 & 0.08 & 0.35 & 0.10 \\
\hline $\mathrm{Fe}_{2} \mathrm{O}_{3}$ & 47.00 & 11.97 & 43.60 & 11.85 & 45.70 & 11.81 & 40.60 & 11.79 & 43.00 & 12.30 \\
\hline $\mathrm{K}_{2} \mathrm{O}(\mathrm{a})$ & 0.60 & 0.15 & 0.60 & 0.16 & 0.60 & 0.16 & 0.60 & 0.17 & 0.60 & 0.17 \\
\hline MgO & 0.79 & 0.20 & 0.89 & 0.24 & 0.65 & 0.17 & 0.59 & 0.17 & 0.35 & 0.10 \\
\hline $\mathrm{MnO}_{2}$ & 11.30 & 2.88 & 10.40 & 2.83 & 10.80 & 2.79 & 9.64 & 2.80 & 1.72 & 0.49 \\
\hline $\mathrm{Na}_{2} \mathrm{O}$ & 61.70 & 15.72 & 54.80 & 14.90 & 57.30 & 14.80 & 51.20 & 14.86 & 52.80 & 15.10 \\
\hline $\mathrm{NiO}$ & 1.77 & 0.45 & 1.62 & 0.44 & 1.75 & 0.45 & 1.54 & 0.45 & 1.58 & 0.45 \\
\hline $\mathrm{P}_{2} \mathrm{O}_{5}$ & 10.40 & 2.65 & 9.78 & 2.66 & 10.00 & 2.58 & 8.63 & 2.51 & 9.10 & 2.60 \\
\hline $\mathrm{RE}_{2} \mathrm{O}_{3}$ & 0.32 & 0.08 & 0.45 & 0.12 & 0.35 & 0.09 & 0.21 & 0.06 & 10.20 & 2.90 \\
\hline $\mathrm{Ru}_{2}$ & 0.40 & 0.10 & 0.44 & 0.12 & 0.00 & 0.00 & 0.28 & 0.08 & 0.28 & 0.08 \\
\hline $\mathrm{SiO}_{2}$ & 176.00 & 44.83 & 161.00 & 43.77 & 169.00 & 43.66 & 155.00 & 45.00 & 156.40 & 44.70 \\
\hline $\mathrm{SO}_{3}(\mathrm{f})$ & 0.70 & 0.18 & 0.70 & 0.19 & 0.70 & 0.18 & 0.70 & 0.20 & 0.70 & 0.20 \\
\hline Sro & 0.24 & 0.06 & 0.22 & 0.06 & 0.23 & 0.06 & 0.21 & 0.06 & 0.10 & 0.03 \\
\hline $\mathrm{TiO}_{2}$ & 0.15 & 0.04 & 0.16 & 0.04 & 0.16 & 0.04 & 0.13 & 0.04 & 0.10 & 0.03 \\
\hline $\mathrm{Y}_{2} \mathrm{O}_{3}(\mathrm{a})$ & 0.07 & 0.02 & 0.07 & 0.02 & 0.07 & 0.02 & 0.07 & 0.02 & 0.07 & 0.02 \\
\hline $\mathrm{ZrO}_{2}$ & 0.10 & 0.03 & 5.68 & 1.54 & 6.66 & 1.72 & 3.66 & 1.06 & 5.88 & 1.68 \\
\hline Total & 392.59 & 100.00 & 367.80 & 100.00 & 386.07 & 100.00 & 344.48 & 100.00 & 349.86 & 100.00 \\
\hline
\end{tabular}

(a) Not analyzed for, assumed target value.

(b) Feed $10 w$ in $2 \mathrm{rO}_{2}$.

(c) Feed adjusted in $\mathrm{ZrO}_{2}$. 
TABLE A.15. Normalized Compositions of Glass Samples Taken During LFMM-86-5

\begin{tabular}{|c|c|c|c|c|c|c|c|c|c|c|c|}
\hline $\begin{array}{c}\text { Hours } \\
\text { Into Run } \\
\text { oxide } \\
\end{array}$ & $\begin{array}{l}\text { Ur } \\
\text { Starting } \\
\text { Glass } \\
\end{array}$ & djuste & $\begin{array}{l}\text { b) } \\
1.00 \\
\# 1 \mathrm{~A} \\
\end{array}$ & $\begin{array}{c}\text { Normal } \\
4.00 \\
\# 2 \mathrm{~A} \\
\end{array}$ & $\begin{array}{c}\text { zed Wei } \\
7.00 \\
\# 3 \mathrm{~A} \\
\end{array}$ & $\begin{array}{c}\text { ht Perc } \\
9.00 \\
\$ 4 \mathrm{~A} \\
\end{array}$ & $\begin{array}{c}12.00 \\
\$ 5 A \\
\end{array}$ & $\begin{array}{c}15.00 \\
\$ 6 \mathrm{~A} \\
\end{array}$ & $\begin{array}{c}18.00 \\
\$ 7 \mathrm{~A} \\
\end{array}$ & $\begin{array}{l}\text { Bulk } \\
\text { Feed } \\
\end{array}$ & Target \\
\hline $\mathrm{Al}_{2} \mathrm{O}_{3}$ & 4.43 & 4.34 & 3.91 & 3.25 & 2.94 & 2.79 & 2.58 & 2.65 & 2.61 & 2.58 & 2.40 \\
\hline $\mathrm{B}_{2} \mathrm{O}_{3}$ & 7.01 & 7.17 & 8.52 & 10.16 & 11.27 & 12.22 & 12.59 & 12.39 & 12.15 & 13.09 & 12.70 \\
\hline $\mathrm{BaO}^{\circ}$ & 0.08 & 0.11 & 0.10 & 0.10 & 0.09 & 0.09 & 0.08 & 0.08 & 0.08 & 0.08 & 0.10 \\
\hline $\mathrm{CaO}$ & 1.55 & 1.46 & 1.68 & 2.06 & 2.26 & 2.33 & 2.36 & 2.39 & 2.42 & 2.48 & 3.00 \\
\hline $\mathrm{CeO}_{2}$ & 0.00 & 0.00 & 0.36 & 1.02 & 1.31 & 1.46 & 1.57 & 1.67 & 1.66 & 1.75 & 0.17 \\
\hline $\mathrm{Cr}_{2} \mathrm{O}_{3}$ & $0 . \mathrm{DO}$ & 0.04 & 0.20 & 0.43 & 0.52 & 0.59 & 0.64 & 0.63 & 0.65 & 0.68 & 0.68 \\
\hline $\mathrm{Cs}_{2} \mathrm{O}^{\circ}$ & 0.00 & 0.08 & 0.11 & 0.10 & 0.10 & 0.10 & 0.10 & 0.09 & 0.08 & 0.08 & 0.10 \\
\hline CuO & 0.00 & 0.00 & 0.00 & 0.04 & 0.00 & 0.00 & 0.00 & 0.00 & 0.00 & 0.00 & 0.00 \\
\hline $\mathrm{Fe}_{2} \mathrm{O}_{3}$ & 10.87 & 10.76 & 11.02 & 11.38 & 11.57 & 11.51 & 11.57 & 11.58 & 11.63 & 11.79 & 12.30 \\
\hline $\mathrm{K}_{2} \mathrm{O}^{(\mathrm{a})}$ & 0.00 & 0.17 & 0.17 & 0.17 & 0.17 & 0.17 & 0.17 & 0.17 & 0.18 & 0.17 & 0.17 \\
\hline $\mathrm{Li}_{2} 0$ & 4.92 & 4.50 & 3.51 & 1.85 & 1.09 & 0.77 & 0.39 & 0.36 & 0.13 & 0.00 & 0.00 \\
\hline $\mathrm{Mg} 0$ & 0.85 & 0.70 & 0.59 & 0.37 & 0.34 & 0.23 & 0.18 & 0.31 & 0.18 & 0.17 & 0.10 \\
\hline $\mathrm{MnO}_{2}$ & 2.79 & 2.68 & 2.68 & 2.71 & 2.72 & 2.76 & 2.74 & 2.72 & 2.73 & 2.80 & 0.49 \\
\hline $\mathrm{Na}_{2} \mathrm{O}$ & 10.87 & 11.16 & 11.73 & 13.51 & 14.29 & 14.14 & 14.74 & 14.73 & 14.75 & 14.86 & 15.10 \\
\hline $\mathrm{NiO}$ & 0.86 & 0.95 & 1.01 & 0.76 & 0.66 & 0.62 & 0.59 & 0.59 & 0.53 & 0.45 & 0.45 \\
\hline $\mathrm{P}_{2} \mathrm{O}_{5}$ & 0.00 & 0.00 & 0.54 & 1.50 & 1.88 & 2.18 & 2.25 & 2.41 & 2.43 & 2.51 & 2.60 \\
\hline $\mathrm{RE}_{2} \mathrm{O}_{3}$ & 0.00 & 0.00 & 0.03 & 0.03 & 0.05 & 0.04 & 0.04 & 0.07 & 0.07 & 0.06 & 2.90 \\
\hline $\mathrm{RuO}_{2}$ & 0.00 & 0.08 & 0.08 & 0.08 & 0.08 & 0.08 & 0.08 & 0.08 & 0.08 & 0.08 & 0.08 \\
\hline $\mathrm{SiO}_{2}^{2}$ & 55.05 & 54.81 & 52.87 & 49.38 & 47.19 & 46.35 & 45.45 & 45.19 & 45.59 & 45.00 & 44.70 \\
\hline $\mathrm{SO}_{3}(\mathrm{a})$ & 0.00 & 0.20 & 0.20 & 0.20 & 0.20 & 0.20 & 0.20 & 0.20 & 0.21 & 0.20 & 0.20 \\
\hline Sró & 0.00 & 0.05 & 0.06 & 0.08 & 0.08 & 0.08 & 0.07 & 0.07 & 0.06 & 0.06 & 0.03 \\
\hline $\mathrm{TiO}_{2}$ & 0.06 & 0.05 & 0.05 & 0.05 & 0.05 & 0.04 & 0.04 & 0.05 & 0.04 & 0.04 & 0.03 \\
\hline$Y_{2} O_{3}^{c}(a)$ & 0.00 & 0.02 & 0.02 & 0.02 & 0.02 & 0.02 & 0.02 & 0.02 & 0.02 & 0.02 & 0.02 \\
\hline $\mathrm{ZnO}$ & 0.00 & 0.00 & 0.00 & 0.00 & 0.00 & 0.00 & 0.00 & 0.00 & 0.00 & 0.00 & 0.00 \\
\hline $\mathrm{ZrO}_{2}$ & 0.67 & 0.66 & 0.56 & 0.74 & 1.11 & 1.22 & 1.50 & 1.55 & 1.71 & 1.06 & 1.68 \\
\hline Total & 100.00 & 100.00 & 100.00 & 100.00 & 100.00 & 100.00 & 100.00 & 100.00 & 100.00 & 100.00 & 100.00 \\
\hline $\mathrm{Fe}^{2+} / \mathrm{Fe}^{3+}$ & 0.03 & 0.00 & 0.00 & 0.00 & 0.00 & $0.0 \mathrm{D}$ & 0.00 & 0.00 & 0.00 & & \\
\hline
\end{tabular}

(a) Not analyzed for, assumed target value.

(b) Feed $10 \mathrm{w}$ in $\mathrm{ZrO}_{2}$, subsequent feed adjusted in $\mathrm{ZrO}_{2}$. 
TABLE A.16. ICP Analyses of Feed Samples Taken Ouring LFMM-86-6

\begin{tabular}{|c|c|c|c|c|c|c|c|c|}
\hline $\begin{array}{l}\text { Hours } \\
\text { Into Run } \\
\end{array}$ & & & & & & & & \\
\hline $\begin{array}{l}\text { Sample } \\
\text { Number }\end{array}$ & & & & & Bulk & eed & Tar & \\
\hline Oxide & $\begin{array}{c}9 / \mathrm{L} \\
\text { oxides }\end{array}$ & $w t \%$ & $\begin{array}{c}\mathrm{g} / \mathrm{L} \\
\text { oxides } \\
\end{array}$ & $\mathrm{wt} \%$ & $\begin{array}{c}g / L \\
\text { oxides }\end{array}$ & wt\% & $\begin{array}{c}\bar{g} / \mathrm{L} \\
\text { 0xides }\end{array}$ & $w t \%$ \\
\hline $\mathrm{Al}_{2}$ & 8.25 & 2.58 & 9.67 & 2.85 & 7.91 & 2.49 & 8.40 & 2.40 \\
\hline $\mathrm{B}_{2} \mathrm{O}$ & 42.50 & 13.31 & 35.40 & 10.45 & 41.90 & 13.18 & 44.40 & 12.69 \\
\hline $\mathrm{BaO}^{3}$ & 0.24 & 0.08 & 0.27 & 0.08 & 0.23 & 0.07 & 0.35 & 0.10 \\
\hline $\mathrm{CaO}$ & 8.40 & 2.63 & 9.02 & 2.66 & 7.74 & 2.44 & 10.50 & 3.00 \\
\hline $\mathrm{CeO}_{2}$ & 5.65 & 1.77 & 6.09 & 1.80 & 5.47 & 1.72 & 0.60 & 0.17 \\
\hline & 2.21 & 0.69 & 2.41 & 0.71 & 2.10 & 0.66 & 2.38 & 0.68 \\
\hline $\mathrm{Cs}_{2} \mathrm{O}^{\mathrm{S}}$ & 0.24 & 0.08 & 0.29 & 0.09 & 0.23 & 0.07 & 0.35 & 0.10 \\
\hline $\mathrm{Fe}_{2} \mathrm{O}_{3}$ & $3 B .40$ & 12.03 & 41.40 & 12.22 & 36.50 & 11.48 & 43.00 & 12.29 \\
\hline $\mathrm{K}_{2} \mathrm{O}^{(\mathrm{d})}$ & 0.60 & 0.19 & 0.60 & 0.18 & 0.60 & 0.19 & 0.60 & 0.17 \\
\hline Mgo & 0.59 & 0.18 & 0.89 & 0.26 & 0.59 & 0.19 & 0.35 & 0.10 \\
\hline $\mathrm{MnO}_{2}$ & 9.12 & 2.86 & 9.90 & 2.92 & 8.69 & 2.73 & 1.72 & 0.49 \\
\hline $\mathrm{Na}_{2} \mathrm{C}$ & 49.50 & 15.50 & 51.90 & 15.32 & 46.30 & 14.57 & 52.80 & 15.09 \\
\hline $\mathrm{NiO}$ & 1.41 & 0.44 & 1.60 & 0.47 & 1.37 & 0.43 & 1.58 & 0.45 \\
\hline $\mathrm{P}_{2} \mathrm{O}_{5}$ & 8.46 & 2.65 & 9.17 & 2.71 & 8.19 & 2.58 & 9.10 & 2.60 \\
\hline & 0.24 & 0.08 & 0.56 & 0.17 & 0.22 & 0.07 & 10.20 & 2.92 \\
\hline $\mathrm{RuO}_{2}$ & 0.00 & 0.00 & 0.47 & 0.14 & 0.28 & 0.09 & 0.28 & 0.08 \\
\hline $\mathrm{SiO}_{2}$ & 142.00 & 44.48 & 150.00 & 44.27 & 141.00 & 44.37 & 156.40 & 44.70 \\
\hline $\mathrm{SO}_{3}(\mathrm{a})$ & 0.70 & 0.22 & 0.70 & 0.21 & 0.70 & 0.22 & 0.70 & 0.20 \\
\hline Srô & 0.19 & 0.06 & 0.22 & 0.06 & 0.19 & 0.06 & 0.10 & 0.03 \\
\hline $\mathrm{TiO}_{2}$ & 0.14 & 0.04 & 0.17 & 0.05 & 0.13 & 0.04 & 0.10 & 0.03 \\
\hline $\mathrm{Y}_{2} \mathrm{O}_{3}(\mathrm{a})$ & 0.07 & 0.02 & 0.07 & 0.02 & 0.07 & 0.02 & 0.07 & 0.02 \\
\hline $\mathrm{ZrO}_{2}$ & 0.37 & 0.12 & 8.05 & 2.38 & 7.40 & 2.33 & 5.88 & 1.68 \\
\hline Total & 319.28 & 100.00 & 338.85 & 100.00 & 317.81 & 100.00 & 349.86 & 100.00 \\
\hline
\end{tabular}

(a) Not analyzed for, assumed target value. 
IABLE A.17. Normalized Compositions of Glass Samples Taken During LFMM-86-6

\begin{tabular}{|c|c|c|c|c|c|c|c|c|c|c|}
\hline $\begin{array}{c}\begin{array}{c}\text { Hours } \\
\text { Into Run }\end{array} \\
\text { oxide } \\
\end{array}$ & $\begin{array}{c}\text { Starting } \\
\text { Glass } \\
\end{array}$ & 1.00 & 4.00 & 7.00 & 9.00 & 12.00 & 15.00 & 18.00 & $\begin{array}{l}\text { Bulk } \\
\text { Feed } \\
\end{array}$ & Target \\
\hline $\mathrm{Al}_{2} \mathrm{O}_{3}$ & 2.61 & 2.64 & 2.55 & 2.54 & 2.62 & 2.62 & 2.55 & 2.61 & 2.49 & 2.40 \\
\hline $\mathrm{B}_{2} \mathrm{O}_{3}$ & 12.15 & 12.46 & 12.52 & 12.41 & 12.87 & 12.82 & 12.76 & 12.88 & 13.18 & 12.70 \\
\hline $\mathrm{BaO}$ & 0.08 & 0.08 & 0.07 & 0.08 & 0.07 & 0.07 & 0.07 & 0.07 & 0.07 & 0.10 \\
\hline $\mathrm{BaO}$ & 2.42 & 2.49 & 2.42 & 2.54 & 2.48 & 2.42 & 2.41 & 2.44 & 2.44 & 3.00 \\
\hline $\mathrm{CeO}_{2}$ & 1.66 & 1.69 & 1.69 & 1.69 & 1.74 & 1.76 & 1.75 & 1.78 & 1.72 & 0.17 \\
\hline $\mathrm{Cr}_{2} \mathrm{O}_{3}$ & 0.65 & 0.65 & 0.65 & 0.69 & 0.72 & 0.67 & 0.65 & 0.64 & 0.66 & 0.68 \\
\hline $\mathrm{Cs}_{2} \mathrm{O}^{\circ}$ & 0.08 & 0.08 & 0.08 & 0.08 & 0.08 & 0.07 & 0.07 & 0.07 & 0.07 & 0.10 \\
\hline CuO & 0.00 & 0.00 & 0.00 & 0.00 & 0.00 & 0.00 & 0.00 & 0.00 & 0.00 & 0.00 \\
\hline $\mathrm{Fe}_{2} \mathrm{O}_{3}$ & 11.63 & 11.53 & 11.71 & 11.51 & 11.25 & 11.39 & 11.50 & 11.47 & 11.48 & 12.30 \\
\hline $\mathrm{k}_{2} 0^{(z)}$ & 0.18 & 0.18 & 0.17 & 0.17 & 0.17 & 0.17 & 0.18 & 0.17 & 0.19 & 0.17 \\
\hline $\mathrm{Li}_{2} \mathrm{O}$ & 0.13 & 0.08 & 0.07 & 0.06 & 0.07 & 0.06 & 0.04 & 0.05 & 0.00 & 0.00 \\
\hline $\mathrm{MgO}$ & 0.18 & 0.20 & 0.15 & 0.18 & 0.26 & 0.26 & 0.24 & 0.26 & 0.19 & 0.10 \\
\hline $\mathrm{MnO}_{2}$ & 2.73 & 2.70 & 2.76 & 2.77 & 2.74 & 2.77 & 2.74 & 2.77 & 2.73 & 0.49 \\
\hline $\mathrm{Na}_{2} \mathrm{O}$ & 14.75 & 14.75 & 14.35 & 14.72 & 14.39 & 14.34 & 14.24 & 14.09 & 14.57 & 15.10 \\
\hline $\mathrm{NiO}$ & 0.53 & 0.56 & 0.56 & 0.57 & 0.60 & 0.62 & 0.57 & 0.52 & 0.43 & 0.45 \\
\hline $\mathrm{P}_{2} \mathrm{O}_{5}$ & 2.43 & 2.47 & 2.49 & 2.55 & 2.61 & 2.61 & 2.54 & 2.67 & 2.58 & 2.60 \\
\hline $\mathrm{RE}_{2} \mathrm{O}_{3}$ & 0.07 & 0.07 & 0.04 & 0.05 & 0.14 & 0.11 & 0.11 & 0.21 & 0.07 & 2.90 \\
\hline $\mathrm{RuO}_{2}$ & 0.08 & 0.08 & 0.08 & 0.08 & 0.08 & 0.08 & 0.08 & 0.08 & 0.09 & 0.08 \\
\hline $\mathrm{SiO}_{2}$ & 45.59 & 45.17 & 45.50 & 44.95 & 44.79 & 44.76 & 45.04 & 44.77 & 44.37 & 44.70 \\
\hline $\mathrm{SO}_{3}{ }^{\mathrm{fa})}$ & 0.21 & 0.21 & 0.20 & 0.20 & 0.20 & 0.20 & 0.21 & 0.20 & 0.22 & 0.20 \\
\hline Sró & 0.06 & 0.06 & 0.06 & 0.06 & 0.06 & 0.06 & 0.06 & 0.06 & 0.06 & 0.03 \\
\hline $\mathrm{TiO}_{2}$, & 0.04 & 0.05 & 0.04 & 0.05 & 0.05 & 0.05 & 0.05 & 0.04 & 0.04 & 0.03 \\
\hline $\mathrm{Y}_{2} \mathrm{O}_{3}(\mathrm{a})$ & 0.02 & 0.02 & 0.02 & 0.02 & 0.02 & 0.02 & 0.02 & 0.02 & 0.02 & 0.02 \\
\hline $\operatorname{Zno}$ & 0.00 & 0.00 & 0.00 & 0.00 & 0.00 & 0.00 & 0.00 & 0.00 & 0.00 & 0.00 \\
\hline $\mathrm{ZrO}_{2}$ & 1.71 & 1.77 & 1.79 & 2.00 & 1.97 & 2.03 & 2.09 & 2.12 & 2.33 & 1.68 \\
\hline Total & 100.00 & 100.00 & 100.00 & 100.00 & 100.00 & 100.00 & 100.00 & 100.00 & 100.00 & 100.00 \\
\hline $\mathrm{Fe}^{2+} / \mathrm{Fe}^{3+}$ & 0.00 & 0.00 & 0.07 & 1.15 & 1.33 & 1.72 & 1.69 & 0.57 & & \\
\hline
\end{tabular}

(a) Not analyzed for, assumed target value. 


\section{DISTRIBUTION}

No. of

Copies

OFFSITE

30 DDE Technical Information Center

6 Geologic Repository Division DOE Office of Civilian Radioactive Waste Management Forrestal Building Washington, DC 20585

ATTN: L. H. Barrett, RH-33

C. R. Cooley, RW-40

J. R. Hilley, RW-30

S. Kale, RW-20

D. E. Shelor, RW-32

R. Stein, RW-23

3 DOE Office of Defense Waste and Transportation Manayement GTN Washington, DC 20545

ATTN: T. C. Chee, DP -123

J. E. Lytle, DP-12

G. H. Daly, DP -123

5 DUE Office of Terminal Waste GTN

Disposal and Remedial Action

Washington, DC 20545

ATTN: J. A. Coleman, NE-24

T. W. McIntos h, NE-24

H. E. Stelling, NE-24

W. R. Voigt, Jr., NE-20

H. F. Walter, NE-24

A. T. Clark

Division of Fuel Materials Safety

Nuclear Regulatory Commission

Washington, DC 20555
No. of

Copies

V. Stello

Office of the Executive

Director for Operations

Mail Station 6209

Nuclear Regulatory Commission

Washington, DC 20555

G. L. Sjoblom

Environmental Protection Agency

Office of Radiation Programs

401 M Street, S.W.

Washington, DC 20460

J. M. McGough

DOE Albuquerque Operations

office

P.0. Box 5400

Albuquerque, NM 87185

P. G. Hagan

Joint Integration Dffice

Bldg. 3, 2nd Floor

2201 San Pedro N.E.

Albuquerque, NM 87110

E. Maestas

DOE West Valley Operations Office

P.0. Box 191

West Valley, NY 14171

2 DOE Idaho Operations Office

550 Second Street

Idaho Falls, ID 83401

ATTN: J. P. Hamric

J. L. Lyle

F. T. Fong

DOE San Francisco Operations

1333 Broadway

Oakland, CA 94612 
No. of

Copies

M. R. Jugan

DOE Oak Ridge Operations Office

P.0. Box E

Oak Ridge, TN 37830

W. J. Brumley

DOE Savannah River Operations Office

P.0. Box A

Aiken, SC 29801

M. J. Steindler

Argonne National Laboratory

9700 South Cass Avenue

Argonne, IL 60439

C. S. Abrams

Argonne National Laboratory

P.0. Box 2528

Idaho Falls, ID 83401

3 Battelle Memorial Institute Project Management Division 505 King Avenue

Col umbus, $\mathrm{OH} 43201$

ATTN: W. A. Carbeiner

W. S. Madia

B. Rawles

D. T. Oakley, MS 671

Los Alamos Scientific Laboratory

P.0. Box 1663

Los Al amos, NM 87544

4 Oak Ridge National Laboratory

P.0. BoX Y

Oak Ridge, TN 37830

ATTN: J. 0. Bl omeke

W. D. Burch

R. T. Jubin

L. J. Mezga

Sandia Laboratories

P.0. Box 5800

Albuquerque, NM 87185

ATTN: Technical Library
No. of

Copies

J. R. Berreth

Westinghouse Idaho Nuclear Company, Incorporated

P.0. Box 4000

Idaho Falls, ID 83401

6 E. I. du Pont de Nemours Company

Savannah River Laboratory

Aiken, SC 29801

ATTN: M. D. Boersma

J. G. Glass cock

E. J. Hennelly

J. R. Knight

M. 3. Plodinec

C. T. Randall

E. A. Jennrich

EG\&G Idaho

P.0. Box 1625

Idaho Falls, ID 83415

R. Shaw

Electric Power Research Institute

3412 Hillview Avenue

P.0. Box 10412

Palo Alto, CA 94304

5 West Valley Nuclear Services Company

P.0. Box 191

West Valley, NY 14171

ATTN: S. M. Barnes

C. C. Chapman

J. E. Krauss

S. J. Marchette

J. M. Pope

J. L. White, Chairman

Energy Research and Development Authority

Empire State Plaza

AlDany, NY 12223 
No. of

Copies

ONSITE

9 DOE Richland Operations Office

J. H. Anttonen

E. A. Bracken

G. J. Bracken

C. E. Collantes

C. R. Delannoy

R. D. Izatt

J. L. Rhoades

M. W. Shupe

J. D. White

12 Rockwell Hanford Operations

R. N. Gurley

J. M. Henderson

H. E. McGuire

J. L. Nelson

R. D. Prosser

J. H. Roecher

J. L. Scott

D. A. Turner

R. N. Wagner

D. D. Wodrich

R. D. Wojtasek

File Copy

UNC United Nuclear Industries

T. E. Dabrowski/W. J. Kyriazia

2 Westinghouse Hanford Company

R. E. Lerch

J. D. Watrous
No. of

Copies

57 Pacific Northwest Laboratory

C. R. Allen

W. W. Ballard, Jr.

S. 0. Bates (2)

W. F. Bonner

R. A. Brouns (2)

J. L. Buelt

L. R. Bunnell

H. C. Burkholder

J. R. Carrell

D. G. Coles

R. D. Dierks

L. J. Ethridge

G. L. Graff (3)

L. K. Holton

R. S. Kemper, Jr.

S. S. Koegler

W. L. Kunn

L. T. Lakey (2)

D. E. Larson

S. C. Marschman

G. D. Maupin

D. McCarthy

J. L. McElroy

G. B. Mellinger

J. E. Minor

S. J. Mitchell

R. K. Nakaoka

J. M. Perez, Jr.

M. E. Peterson

M. A. Reimus (10)

P. W. Reimus

P. A. Scott

G. J. Sevigny

J. L. Straalsund

N. M. Thomas

J. H. Westsik, Jr.

Technical Report Files (5)

Publishing Coordination (2) 


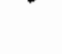

